\title{
DETERMINAÇÃO DAS EXIGÊNCIAS TÉRMICAS E HÍDRICAS DO FUNGO Metarhizium anisopliae (METSCH.) SOROKIN, 1883
}

\author{
ROBERTO TEIXEIRA ALVES
}

Engenheiro Agrônomo

Orientador: Prof. Dr. SÉRGIO BATISTA ALVES

Dissertação apresentada à Escola Superior de Agricultura "Luiz de Queiroz", da Universidade de São Paulo, para obtenção do título de Mestre em Ciências Biológicas Área de Concentração: Entomologia.

\footnotetext{
$P|R A C| C A B A$

Estado de São Paulo - Brasil Julho - 1986
} 
. $i i$.

A minha querida esposa Elisabete, OFEREÇO E DEDICO. 


\section{AGRADEC IMENTOS}

0 autor agradece, em primeiro lugar, a "DEUS" por ter lhe sustentado durante toda a sua vida e especialmente nos momentos difíceis da realização deste trabalho, e às se guintes pessoas e instituições:

- A Empresa Brasileira de Pesquisa Agropecuária (EMBRAPA) pela oportunidade concedida para que este trabalho pudesse ser realizado.

- Ao Dr. Sérgio Batista Alves, Professor Adjunto do Departamento de Entomologia da Escola Superior de Agricultura "Luiz de Queiroz" (ESALQ) por sua orientação, amizade e estímulo constante na execução deste trabalho.

- Ao Dr. Sinval Silveira Neto, Professor Titular e Chefe do Departamento de Entomologia da ESALQ/USP, pelas sugestões concedidas.

- A Dra. Marinéia de Lara Haddad e à M.Sc. Orghêda L. A. Domingues Zucchi, pelo apoio estatístico.

- Aos professores do Curso de Pós-Graduação em Entomolo gia da ESALQ/USP, pelos ensinamentos transmitidos.

- Ao IAA/PLANALSUCAR de Araras, S̀ão Paulo, nas pessoas do Dr. Paulo Sérgio M. Botelho e Dr. Luiz Carlos Almeida, pe1o fornecimento das lagartas de Diatraea saccharalis (Fabr.)pa ra os experimentos. 
- Ao.Dr. José Roberto P. Parra, Professor Adjunto do Departamento de Entomologia da ESALQ/USP, por seu apoio e sugestões concedidas.

- Ao Dr. Rogério Remo Alfonsi, Pesquisador da Seção de Climatologia Agrícola do Instituto Agronômico de Campinas, por seu apoio e sugestões concedidas.

- Ao Técnico de Laboratório Paulo Roberto Casarin Kawai, pelas fotografias e por sua boa vontade durante a realização deste trabalho.

- As colegas de curso, Artemísia M. Vilas Boas, Gláucia Maria B. Ambrosano e Maria Elisabete G. Folegatti por suas valiosas contribuições na realização deste trabalho.

- Aos meus pais Helio e Lucila, e à minha esposa Elisabete, pelo carinho, colaboração e constante estímulo, a minha since ra gratidão. 
INDICE

Página

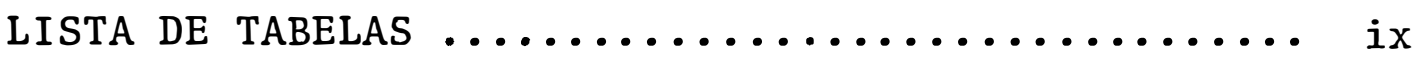

LISTA DE FIGURAS E APENDICE $\ldots \ldots \ldots \ldots \ldots \ldots \ldots \ldots$ xvi

RESUMO $\ldots \ldots \ldots \ldots \ldots \ldots \ldots \ldots \ldots \ldots \ldots \ldots \ldots \ldots \ldots \ldots \ldots \ldots \ldots$

SUMMARY $\ldots \ldots \ldots \ldots \ldots \ldots \ldots \ldots \ldots \ldots \ldots \ldots \ldots \ldots \ldots \ldots \ldots \ldots \ldots \ldots \ldots \ldots$

1. INTRODUÇAO $\ldots \ldots \ldots \ldots \ldots \ldots \ldots \ldots \ldots \ldots \ldots \ldots \ldots \ldots \ldots \ldots$

2. REVISÁO DE LITERATURA $\ldots \ldots \ldots \ldots \ldots \ldots \ldots \ldots \ldots$

2.1. Considerações sobre o fungo Metarhizium anisopliae ....................... 4

Ż.2. Classificação, descrição e modo de ação do fungo M. anisopliae ................ 6 2.2.1. Classificação do fungo M. anisopliae 6 2.2.2. Descrição do fungo M. anisopliae ... 7 2.2.3. Modo de ação do M. anisopliae no hos pedeiro ................... 8

2.3. Doença e seu progresso em uma população de insetos ........................ 10

2.4. Fatores que afetam a ocorrência de epizootias de M. anisopliae ................. 12 2.4.1. Fatores biōticos ............. 12 2.4.2. Fatores abióticos ............ 17 2.4.2.1. Influência da temperatura . 18 2.4.2.2. Influência da umidade .... 25 


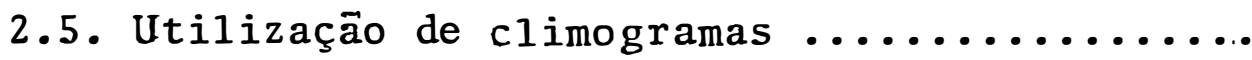

3. MATERIAL E METODOS .................... 34

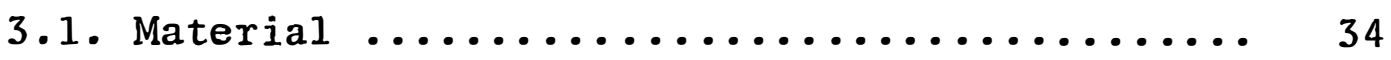

3.1.1. Isolados do fungo Metarhizium anisopliae 34

3.1.2. Inseto utilizado ............. 35

3.1.3. Meio de cultura ............. 36

3.1.4. Equipamentos ............... 36

3.2. Métodos ............................ 39

3.2.1. Calibração da temperatura no interior dos dessecadores ........... 40

3.2.2. Calibração da umidade relativa do ar no interior dos dessecadores ....... 40

3.2.3. Preparo dos inóculos utilizados $\therefore$ na pesquisa $\ldots \ldots \ldots \ldots \ldots \ldots \ldots \ldots . \ldots \ldots$

3.2.4. Inoculação e tipo de lagarta utiliza da na pesquisa ............... 44

3.2.5. Potencial de inóculo dos isolados de

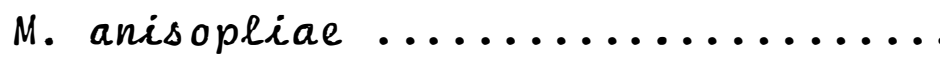

3.2.6. Determinação da produção de conídios de M. anisopliae sobre cadáveres de lagartas de 0 . saccharalis em diferen tes condições de temperatura e umidade relativa do ar ............. 48 
3.2.7.. Determinação da viabilidade dos coní dios de M. anisoplial produzidos sobre cadâveres de lagartas de $D$. saccharalis submetidos a diferentes condições de temperatura e umidade do ar $\ldots \ldots \ldots \ldots \ldots \ldots \ldots \ldots \ldots \ldots \ldots$

3.2.8. Utilização de M. anisopliae com base em climogramas

4. RESUltados E DISCUSSAo $\ldots \ldots \ldots \ldots \ldots \ldots \ldots$

4.1. Potencial de inóculo dos isolados de $M$.

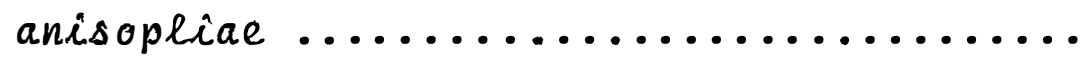

4.2. Determinação da produção de conídios de $M$. anísopliale sobre cadáveres de lagartas de D. saccharalis em diferentes condições de temperatura e umidade relativa do ar ..... . 56

4.3. Determinação da viabilidade dos conídios de M. anisopliae produzidos sobre cadáveres de lagartas de $D$. saccharalis submetidos a diferentes condições de temperatura e umidade

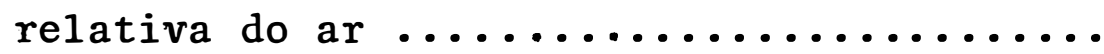

4.4. Utilização de M. anisopliae com base em climogramas .................... 100

5. CONCLUSOES ........................ 110 
.viii

6. LITERATURA CITADA ....................... 115

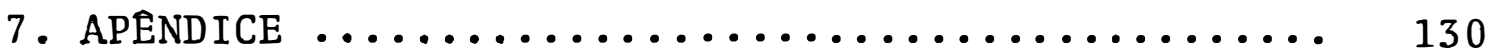




\section{LISTA DE TABELAS}

Tabela

Página

1 Efeito da temperatura "in vitro", sobre a germinação dos conídios, crescimento vegeta tivo e conidiogênese de Metarhizium anisopliae (Metsch.) Sorok. (adaptado de ROBERTS

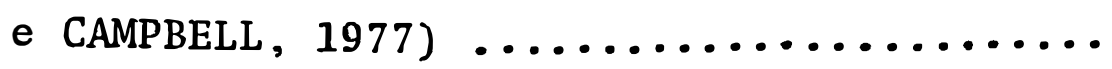

2 Relação dos isolados de Metarhizium anisopliae utilizados, com suas respectivas deno minaçōes, procedências e hospedeiros origi-

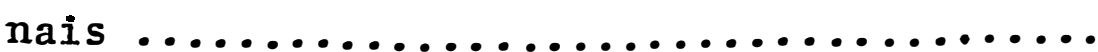

3 Concentrações e volumes da solução de ácido sulfúrico para controle da umidade relativa do ar no interior de um dessecador $\therefore$ com $3.500 \mathrm{~cm}^{3}$ de volume, em diferentes temperaturas $\ldots \ldots \ldots \ldots \ldots \ldots \ldots \ldots \ldots \ldots$

4 Quantidade de conídios dos três isolados de M. anisopliae encontrada no tegumento de lagartas de $5^{\circ}$ instar de $D$. saccharalis após imersão na suspensão fúngica cucontendo $5,4 \times 10^{7}$ conídios $/ m 1 \ldots \ldots \ldots \ldots \ldots \ldots \ldots$ 
5 Produção de conídios de três isolados de $M$. anisopliae sobre cadáveres de lagartas de 5: Instar de D. saccharalis em diferentes períodos de tempo e temperaturas, na umidade relativa do ar de $90 \% \ldots . . \ldots \ldots \ldots$

6 Produção de conídios de três isolados de $M$. anisopliae sobre cadáveres de lagartas de 59 Ínstar de D. saccharalis em idiferertes períodos de tempo e umidades relativas do ar, na temperatura de $26 \pm 0,2^{\circ} \mathrm{C}$...........

7 Produção de conídios de três isolados de $M$. anisopliae sobre cadáveres de lagartas de 5 : Instar de 0. saccharalis, em diferentes conḍiçōes de temperatura e umidade relativa

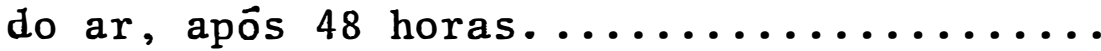

8 Produção de conídios de três isolados de. M. anisopliae sobre cadáveres de lagartas de 59 Instar de 0 . saccharalis em : diferentes condiçōes de umidade relativa do ar, na tem peratura de $34 \pm 0,2^{\circ} \mathrm{C}$, após 48 horas.....

9 Produção de conídios de três isolados de $M$. anisopliae sobre cadáveres de lagartas de 5: Instar de D. saccharalis em diferentes condiçōes de umidade relativa do ar, na temperatura de $30 \pm 0,2^{\circ} \mathrm{C}$, após 48 horas.... 
10 Produção de conídios de três isolados de $M$ : anisopliae sobre cadáveres de lagartas de $5^{\circ}$ instar de $D$. saccharalis em difentes condições de umidade relativa do ar, na tempera tura de $26 \pm 0,2^{\circ} \mathrm{C}$, após 48 horas............

11 Produção de conídios de três isolados de $M$. anisopliae sobre cadāveres de lagartas de $5^{\circ}$ ínstar de $D$. saccharalis em diferentes condi ções de umidade relativa do ar, na temperatu

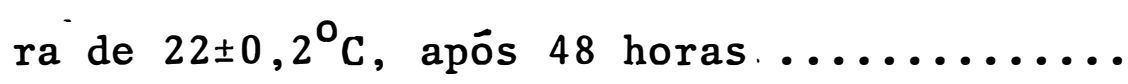

12 Produção de conídios de três isolados de $M$. anisopliae sobre cadāveres de lagartas de $5^{\circ}$ instar de D.saccharalis em diferentes condi ções de temperatura, na umidade relativa do ar de $90 \%$, após 48 horas ...............

13 Produção de conídios de três isolados de $M$. anisopliae sobre cadáveres de lagartas de 5: ínstar de $D$. saccharalis em diferentes condi. ções de temperatura, na umidade relativa do

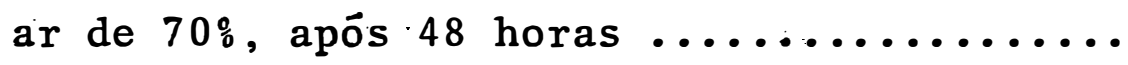

14 Produção de conídios de três isolados de $M$. anisopliae sobre cadáveres de lagartas de $5^{\circ}$ ínstar de $D$. saccharalis em diferentes condi ções de temperatura, na umidade relạtiva do

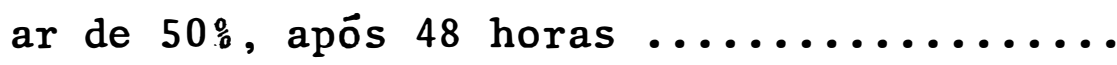


15 Produção de conídios de três isolados de $M$ : anisopliae sobre cadáveres de lagartas de 5: instar de $D$. saccharalis em diferentes condições de temperatura, na umidade relati va do ar de $30 \%$, após 48 horas............

16 Viabilidade dos conídios de três isolados de M. anisopliae, produzidos sobre cadáve res de lagartas de $5^{\circ}$ instar de 0 .saccharalis submetidos a diferentes períodos de tempo e temperaturas, na umidade relativa.: do ar de $90 \% \ldots \ldots \ldots \ldots \ldots \ldots \ldots \ldots \ldots \ldots \ldots \ldots$

17 Viabilidade dosconídios de três isolados de M. anisopliae, produzidos sobre cadáveres de lagartas de $5^{\circ}$ instar de D.saccharalis submetidos a diferentes períodos de tempo e umidades relativas do ar, na temperatura de $26 \pm 0,2^{\circ} \mathrm{C}$.

18 Viabilidade dos conídios de três isolados de M. anisopliae, produzidos sobre cadáveres de lagartas de $5^{\circ}$ instar de D.saccharalis submetidos a diferentes condições de temperatura e umidade relativa do ar, após

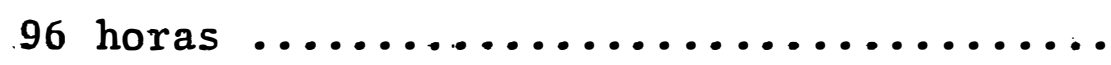


Tabela

Pāgina

19 Viabilidade dos conídios de três isolados

de M. anisopliae, produzidos sobre cadáveres de lagartas de $5^{\circ}$ instar de D.saccharalis submetidos a diferentes umidades relativas do ar, na temperatura de $34 \pm 0,2^{\circ} \mathrm{C}, \quad$ após

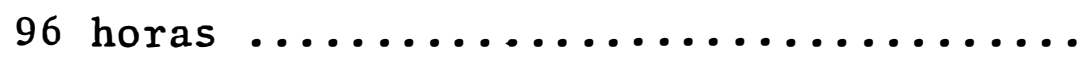

20 Viabilidade dos conídios de três isolados de M. anisopliae, produzidos sobre cadáveres de lagartas de $5^{\circ}$ instar de D.saccharalis submetidos a diferentes umidades relativas do ar, na temperatura de $30 \pm 0,2^{\circ} \mathrm{C}$, após

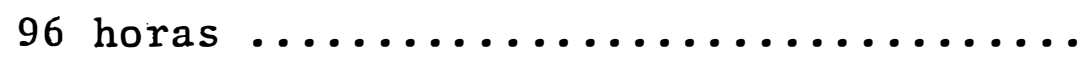

21 Viabilidade dos conídios de três . isolados de M. anisopliae, produzidos sobre cadáveres de lagartas de $5^{\circ}$ instar de $D$ saccharalis submetidos a diferentes umidades relativas do ar, na temperatura de $26 \pm 0,2^{\circ} \mathrm{C}$, após

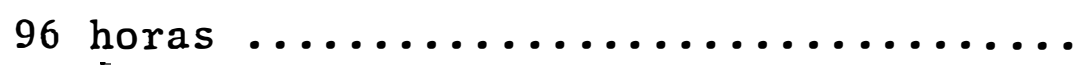

22 Viabilidade dos conídios de três ... isolados de M. anisopliae, produzido sobre cadáve res de lagartas de $5^{\circ}$ instar de D.saccharalis submetidos a diferentes umidades relativas do ar, na temperatura de $22 \pm 0,2^{\circ} \mathrm{C}$, após

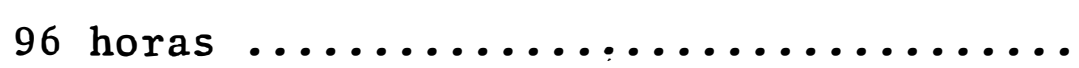


23 Viabilidade dos conídios de três isolados de M. anisopliae, produzidos sobre cadáveres de lagartas de $5^{\circ}$ instar de D.saccharalis submetidos a diferentes temperaturas, na umi dade relativa do ar de $90 \%$ após 96 horas.

24 Viabilidade dos conídios de três isolados de M. anisopliae, produzidos sobre cadáveres de lagartas de $5 \%$ instar de D.saccharalis submetidos a diferentes temperaturas, na umi dade relativa do ar de $70 \%$, após 96 horas.

25 Viabilidade dos conídios de três isolados de M. anisopliae, produzidos sobre cadáveres de lagartas de $5^{\circ}$ instar de $D$. saccharalis submetidos a diferentes temperaturas, na umi dade relativa do ar de 50\%, após 96 horas.

26 Viabilidade dos conídios de três isolados de M. anisopliae, produzidos sobre cadáveres de lagartas de $5^{\circ}$ instar de 0 . saccharalis submetidos a diferentes temperaturas, na umi dade relativa do ar de $30 \%$, após 96 horas. 
27 Condições de temperatura e umidade relativa do ar favoráveis à uma alta produção de conídios por cadáver de lagarta de $5^{\circ}$ instar de $D$. saccharalis e à manutenção de : alta viabilidade dos conídios dos isolados $E_{9}$, PL-27 e PL-43 de M. anisopliae ......... 102 


\section{LISTA DE FIGJRAS F APENDICE}

Figura

Página

1 Estufa incubadora BOD com temperatura e fotofase controladas contendo dessecado res com umidades relativas do ar ajusta das e caixas plásticas com tampa tela-

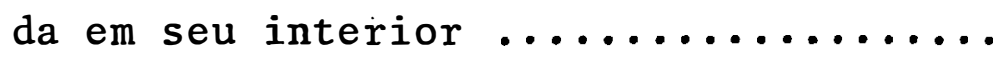

2 Aspecto das lagartas, 24 horas após a morte causada por M. anisopliae, incuba das a $26 \pm 0,2^{\circ} \mathrm{C}$, fotofase de 16 horas e umidade relativa próxima à saturação ..

3 Desenvolvimento dos isolados $E_{9}$, PL-27 e PL-43 de M. anisopliae sobre cadáve res de lagartas de $D$. saccharalis incubados durante 12 horas a $26 \pm 0,2^{\circ} \mathrm{C}$ de temperatura e $90 \%$ de umidade relativa

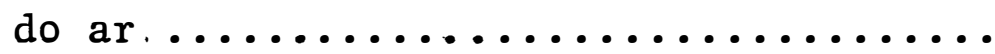

4 Desenvolvimento dos isolados $E_{9}$, PL-27 e PL-43 de M. anisopliae sobre cadáveres de lagartas de 0 . saccharalis incubados durante 24 horas a $26 \pm 0,2{ }^{\circ} \mathrm{C}$ de temperatura e $90 \%$ de umidade relativa do ar .. 
5 Desenvolvimentis dos isolados $\mathrm{E}_{9}, \mathrm{PL}-27$ e PL-43 de M. anisopliae sobre cadáveres de lagartas de 0 . saccharalis incu bados durante 48 horas a $26 \pm 0,2^{\circ} \mathrm{C}$ de temperatura e $90 \%$ de umidade relativa do ar $\ldots \ldots \ldots \ldots \ldots \ldots \ldots \ldots \ldots \ldots \ldots \ldots \ldots \ldots \ldots \ldots \ldots$

6 Produção de conídios do isolado $E_{9}$ de M. anisopliae sobre cadáveres de lagar tas de $5^{\circ}$ instar de $D$. saccharalis em diferentes períodos de tempo e temperaturas, na umidade relativa do ar de $90 \%$.

7 Produção de conídios do isolado $E_{9}$ de M. anisopliae sobre cadáveres de lagartas de 5 : instar de 0 . saccharalis em diferentes períodos de tempo e umidade relativas do ar, na temperatura de

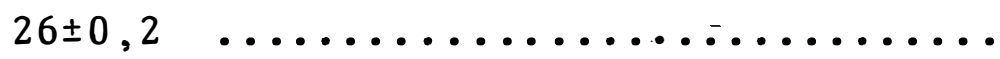

8 Desenvolvimento do isolado $E_{9}$ de $M$. anisopliae sobre cadáveres de lagartas de 0 . saccharalis incubados durante 48 horas na temperatura de $26 \pm 0,2^{\circ} \mathrm{C}$ em diferentes umidades relativas do ar.... 
Figura

Pāgina

9 Desenvolvimento do isolado $E_{9}$ de M. ani sopliae sobre cadáveres de lagartas de D. saccharalis incubados durante 48 horas na umidade relativa do ar de $90 \%$, em diferentes temperaturas ............

10 Viabilidade dos conídios do isolado $E_{9}$ de M. anisopliae produzidos sobre cadāveres de lagartas de $5^{\circ}$ instar de D. saccharalis incubados em diferentes umidades relativas do ar, durante diferentes períodos de tempo, na temperatura de $26 \pm 0,2^{\circ} \mathrm{C} \ldots \ldots \ldots \ldots \ldots \ldots$

11 Climograma comparativo entre a região de Bèēm (PA) e a zona favorável à uma alta produção de conídios viáveis dos iso lados $E_{9}, \mathrm{PL}-27$ e $\mathrm{PL}-43$ de $M$. anisopliae

105

12 Climograma comparativo entre a região de Quixadá (CE) e a zona favorável à uma alta produção de conídios viáveis dos isolados $\mathrm{E}_{9}, \mathrm{PL}-27$ e PL-43 de Metarhi -

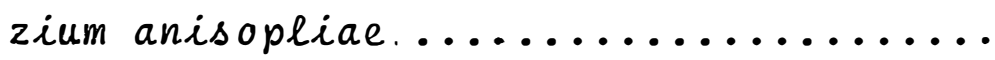


. $x$ ix.

Figura

Pāgina

13 Climograma comparativo entre a região de Cuiabá (MT) e a zona favorāvel à uma al ta produção de conídios viáveis dos iso 1 ados $\mathrm{E}_{9}, \mathrm{PL}-27$ e $\mathrm{PL}-43$ de Metarhizium

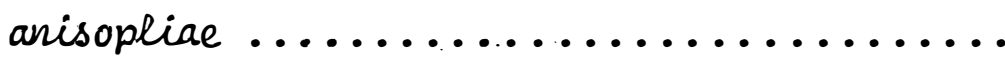

14 Meses com temperaturas médias e umida des relativas médias favoráveis para aplicação dos isolados $\mathrm{E}_{9}, \mathrm{PL}-27$ e PL-43 de Metarhizium anisopliae em diferentes regiões do Brasil ................

Apêndicè 1 Temperaturas mẻdias mensais e umidades re lativas médias mensais de diferentes re giōes do Brasil ................. 


\section{DETERMINACĀA DAS EXIGENCIAS TÉRMICAS E HİDRICAS \\ DO FUNGO Metarhizium anisopliae \\ (Metsch.) Sorokin, 1883}

Autor: ROBERTO TEIXEIRA ALVES

Orientador: Dr. SERGIO BATISTA ALVES

\section{RESUMO}

O objetivo desta pesquisa foi determinar as exigências térmicas e hídricas dos isolados $E_{9}$, PL-27 e PL-43 de Metarhizium anisopliae (Metsch.) Sorokin para obtenção de uma elevada produção de conídios viáveis desse patógeno e desenvolver um método com a utilização de climogramas, para se determinar quais as regiões e as épocas do ano : mais indicadas para a aplicação desse fungo. O trabalho foi realizado no Laboratório de Patologia de Insetos do Departamento de Entomologia da ESALQ/USP, Piracicaba, SP. Lagartas de $5^{\circ}$ instar de Diatraea saccharalis (Fabr.) foram inoculadas com $3,8 \times 10^{5}$ conídios por lagarta, para cada isolado, e em seguida (24 ho ras após a morte) os cadáveres foram mantidos nas temperaturas de $22 \pm 0,2 ; 26 \pm 0,2 ; 30 \pm 0,2$ e $34 \pm 0,2{ }^{\circ} \mathrm{C}$ associadas às umidades relativas do ar de $30,50,70$ e $90 \%$, durante diferentes pe ríodos de tempo. Após a retirada dos cádáveres do interior dos 
dessecadores, realizou-se a contagem dos conídios produzidos sobre esses cadâveres com o auxílio da câmara de Neubauer. De terminou-se tambêm a viabilidade dos conídios em meio de cultura BDA. Em função dos resultados obtidos, foi poșsível concluir que: a) o tempo de 48 horas de incubação é o mais indicado para se comparar a produção de conídios em diferentes tem peraturas e umidades relativas do ar; b) as produções de coní dios mais elevadas foram obtidas nas temperaturas de $26{ }^{\circ} \mathrm{C}$ associada a umidades de 90 e $70 \% ; 22^{\circ} \mathrm{C}$ associada a umidades de $30,50,70$ e $90 \% ; 30^{\circ} \mathrm{C}$ associada a umidades de 90 e $70 \%$ c) a produção de conîdios foi baixa em qualquer umidade quando a tempe ratura ềde $34^{\circ} \mathrm{C}$; d) a temperatura de $22{ }^{\circ} \mathrm{C}$ inibiu a influência das diferentes umidades sobre a produção de conídios; e) o tempo de 96 horas de incubação é o mais indicado para se comparar a viabilidade dos conídios produzidos sobre cadáveres de 0 . saccharalis em diferentes temperaturas e umidades relativas do ar; f) a viabilidade dos conídios manteve-se próxima de 100\%, após 96 horas, nas temperaturas de, $22{ }^{\circ} \mathrm{C}$ associada a umidades iguais ou superiores a $50 \% ; 26^{\circ} \mathrm{C}$ associada a umidades iguais ou superiores a $70 \%$, a 30 e $34 \%$ associadas à umidade de $90 \%$; g) as exìgêncìas têrmicas e hîdricas para se obter alta prodụ ção de conîdios e para a manutenção da viabilidade desses conídios próxima de $100 \%$, são atendidas nas temperaturas de, $22^{\circ} \mathrm{C}$ associada a umidades iguais ou superiores a $50 \% ; 26^{\circ} \mathrm{C}$ as sociada a umidades iguais ou superiores a $70 \% ; 30^{\circ} \mathrm{C}$ associada a umidades iguais ou superiores a $90 \%$; h) a utilização de 
climogramas com base nas exigências térmicas e hídricas dos isolados de M. anisopliae, demonstrou ser útil para a determi nação da êpoca de aplicação e previsão da ocorrência de epizootias nas diferentes regiōes do país. 


\title{
DETERMINATION OF THE TEMPERATURE AND MOISTURE REQUIREMENTS OF THE FUNGUS Metarhizium anisopliae (METSCH.) SOROKIN, 1883
}

\author{
Author : ROBERTO TEIXEIRA ALVES \\ Adviser: Dr. SERGIO BATISTA ALVES
}

\section{SUMMARY}

The objective of this research was to determine the temperature and moisture requirements of the Metarhizium anisopliae (Metsch.) Sorokin isolates $\mathrm{E}_{9}, \mathrm{PL}-27$ and PL-43 for obtaining a high production of viable spores of this pathogen and developing a method utilizing climatograms in order to determine the most favorable regions and times of the year for application of this fungus. The study was conducted in the Insect Pathology Laboratory of the Department of Entomology, ESALQ/USP, Piracicaba, São Paulo - Brazil. Fifth instar larvae of Diatraea saccharalis (Fabr.) were inoculated with $3,8 \times 10^{5}$ spores per larvae; for each isolate. The cadavers ( 24 hours after death), were maintained under temperatures of $22 \pm 0,2 ; 26 \pm 0,2 ; 30 \pm 0,2^{\circ} \mathrm{C}$ and $34 \pm 0,2^{\circ} \mathrm{C}$ associated with relative-humidities of the air of $30,50,70$ and $90 \%$, for different periods of time. After removing the cadavers from the dessiccators, the spores produced on these cadavers 
were counted utilizing the Neubauer chamber. The viability of the spores in PDA culture was also detemined. The results obtained led to the following conclusions: a) 48 hours is the most favorable incubation period of time for comparing spore production under different temperatures and relative humidities of the air; the highest spore productions were obtained at temperatures of $26^{\circ} \mathrm{C}$ associated with humidities of 90 and $70 \% ; 22^{\circ} \mathrm{C}$ associated. with humidities of $30,50,70$ and $90 \% ; 30^{\circ} \mathrm{C}$ associated with humidities of 90 and $70 \%$; c) spore production was 1 ow at any humidity at $34^{\circ} \mathrm{C}$; d). the temperature of $22^{\circ} \mathrm{C}$ inhibited the influence of different humidities on spore production; e) 96 hours was the most favorable incubation time for comparing the viability of spores produced on $D$. saccharalis cadavers under different temperatures and relative humidities of the air; f) spore viability was maintained close to $100 \%$, after 96 hours, at temperatures of $22^{\circ} \mathrm{C}$ associated with humidities equal to or above $50 \% ; 26^{\circ} \mathrm{C}$ associated with humjdities equal to or above $70 \%$; at 30 and $34^{\circ} \mathrm{C}$ associated with $90 \%$ humidity; g) the temperature and moisture requirements for obtaining a high spore production and for maintaining the viability of such spores near $100 \%$ are met at the temperatures of $22^{\circ} \mathrm{C}$ associated with humidities equal to or above $50 \% ; 26^{\circ} \mathrm{C}$ associated with humidities equal to or above $70 \% ; 30^{\circ} \mathrm{C}$ associated with humidities equal to or above $90 \%$; h) the utilization of climatograms based on the temperature and.moisture requirements of M.. anisopliae isolates was shown to be useful for determining the time of application and for 
predicting the occurrence of epizooties in different regions of the country. 


\section{INTRODUCEAO}

0 fungo Metarhizium anisopliae (Metsch.). Soro kin têm sido bastante estudado nos ūltimos anos, pois é consi derado um importante patógeno de värias espécies de insetos, tais como cigarrinhas-das-pastagens, cigarrinhas-da-cana-de-a çúcar e também por apresentar um grande potencial, a ser desenvolvido, para o controle de broca-da-cana-de-açúcar, perce vejos de soja e outros insetos.

Vários trabalhos demonstram que o emprego do M. anisopliae como inseticida microbiano é bastante vâlido, porém existem alguns problemas que devem ser resolvidos para que sua eficiência no controle da praga a nível de campo seja mais elevada, sendo necessário o desenvolvimento de pesquisas sobre os fatores que regulam as epizootias nas diferentes regiōes onde se deseje aplicar este fungo como inseticida microbiano. 
Os fatores que determinam uma epizootia podem ser classsificados como bióticos e abióticos. Os fatores bióticos estão relacionados aos hospedeiros e patógenos e os abióticos estão correlacionados ao ambiente.

As condições ambientais que podem ou não favorecer a ocorrência de epizootias são: temperatura, umidade re lativa do ar ou do solo, radiação solar e presença de substân cias químicas na folhagem ou no solo. E para o caso do fungo M. anisopliae, pode-se dizer que as condições que basicamente influenciam são temperatura, umidade e radiação solar (raios ultravioleta), sendo que esta última pode ser bastante amenizadas com o uso de formulações adequadas, uso de isolados mais resistentes ou com a aplicação do fungo em horários adequados.

Em vista da necessidade de se conhecer melhor a conidiogênese do.M.:anisopliae em diferentes condições de temperatura e umidade relativa do ar sobre um inseto hospede ro, elaborou-se esta pesquisa para se verificar a influência desses dois fatores abióticos sobre essa importante fase do ciclo biológico desse patógeno, que é responsável pela produção de uma grande quantịdade de propágulos, os quais serão disseminados por agentes como vento, chuva, orvalho, animais e pelo próprio homem.

Também, procura-se demonstrar a influência da temperatura e da umidade relativa do ar sobre a viabilidade dos conídios produzidos e expostos a períodos variáveis de 
tempo nas diferentes condições climáticas.

Com base nesses conhecimentos, seria possível elaborar climogramas com os dados de temperatura e umidade das diferentes regiões onde se desejar aplicar o fungo, e com os limites superiores e inferiores de temperatura e umidade rela tiva do ar mais favoráveis à conidiogênese e à manutenção da viabilidade dos conídios próxima de $100 \%$, verificando-se a possibilddade ou não dessa aplicação, assim como a determinação da época do ano mais indicada à realização da mesma. Dessa maneira, pode-se fazer um zoneamento ecológico para os iso lados de M. anisopliae testados sendo que, nas regiões e épocas favoráveis, a probabilidade de ocorrência de epizootia, a partir de uma aplicação do fungo, será elevada. 


\section{REVISAOO DE LITERATURA}

\subsection{CONSIDERAC,ÕES SOBRE o FUNGo Metarhizium anisopliae}

o fungo Metarhizium anisopliae è atualmente um dos microrganismos mais utilizados no controle biológico de pragas, principalmente no Brasil onde vem sendo multiplicado em maior escala por laboratórios de órgãos governamentais e por empresas privadas, para sua posterior aplicação no campo.

Um organismo para ser considerado aceitável dentro de esquema de controle microbiano segundo DUNN e MECHALAS (1963), deve cumprir três exigências para determinar sua adaptabilida de: (a) o organismo deve provar sua habilidade em reduzir a população de insetos de importância econômica; (b) o organismo não deverá ser patogệnico nem tóxico para animais de sangue quente, incluindo o homem; (c) o organismo deve ser produ 
tivo e econômico quando usado em escala comercial para um con trole efetivo. E no caso do M. anisopliae, este patógeno tem cumprido estas exigências, pois desde o primeiro trabalho de controle microbiano realizado por Metschnikoff (1879), citado por SANTOS (1978), que aplicou M. anisopliae para o controle do curculionídeo Cleonus punctiventris Germ., praga de beter raba, até o dia de hoje, ficou demonstrado que este fungo é capaz de reduzir populações de insetos considerados pragas. Segundo FARGUES et alii (1975), o M. anisopliae ataca cerca de 204 espécies de insetos, sabendo-se hoje que este número é bem maior. Quanto ao fato do M. anisopliae não ser patogê nico ou tóxico aos animais de sangue quente, CAMERON (1963) cí ta que não há evidência na literatura de que fungos entomopatogênicos sejam perigosos para animais superiores ouplantas.

VENTURA (1981) demonstrou que, após inocular $M$. anisopliae em camundongos por via intraperitoneal, intravenosa, subcutânea, intramuscular, ingestão e inalação, não houve evidência clínica ou patológica nos animais testados e após a nálises cưddadosas não se observou germinação de conídios nem desenvolvimento do fungo nos tecidos inoculados.

Em relação à terceira exigência comentada por DUNN e MECHALAS (1963), o M. anisopliae no caso tem sido produtivo e econômico (AQUINO et alii, 1975), porém, tem havido alguns problemas na perda da qualidade no armazenamento como a queda de viabilidade dos conídios, que segundo ALVES (1982) decorre de um armazenamento em condições inadequadas, devıdo à 
falta de informaçōes mais precisas sobre o assunto.

Trabalhos como os de CLERK e MADELIN (1965), BELL e HAMALLE (1974), ALVES (1982), DAOUST et alii (1982), DAOUST et alii (1983) e DAOUST e ROBERTS (1983) demonstram a possibilidade de se preservar a viabilidade e a virulência do M. anisopliae em laboratórios por longos períodos de tempo, $\underline{u}$ tilizando-se de temperaturas baixas, umidades relativas controladas e farmulaçōes adequadas do patógeno.

Se a etapa de armazenamento parece estar quase vencida, o mesmo não acontece após a aplicação do fungo a nível de campo, pois existem alguns fatores não controláveis que podem afetar a germinação, reprodução e disseminação do fungo, não permitindo que ocorram epizootias, que proporcionariam o controle da praga a nível desejado.

DIAMONDE (1969) em seu trabalho, relata que as condiçōes ambientais têm grande influência sobre o fungo e, devi do ao fato das mesmas nằo se reproduzirem a contento no campo, o fungo pode não apresentar o resultado desejado.

\subsection{ClassificAÇÃO, DESCRIÇÃO E MODO DE AÇÃO DO FUngO M. anisopliae}

2.2.1. CLASSIFICAÇÃO DO FUNGO M. anisopliae

O fungo M. anisopliae é um patógeno da classe 
Hyphomycetes, ordem Moniliales e família Moniliaceae e segundo PETCH (1931) e KENDRICK (1971) foi classificado pela primeira vez por Metschnikoff em 1879 como Entomophthora anisopliae na praga do milho Anisopliae austriaca, sendo que em 1880, o mesmo autor deu um novo nome ao fungo, Isaria destruc tor. Após algumas proposições de novos nomes como as de Delacroix e de Vuillemim, citados por PETCH (1931), o que prevale ceu foi o de Metarhizium anisopliae classificado por Sorokin em 1883, conforme GUAGLIUMI et alii (1974).

\subsubsection{DESCRICÃO DO FUNGO $M$ : anisopliae}

Na descrição do fungo M. anisopliae, BARON (1968) relata que este patógeno possui um corpo de frutificação seme lhante a um esporodóquio agregado a hifas entrelaçadas, contendo uma massa compacta de conidióforos num estroma plano ou em forma de disco; os conidióforos simples ou ramificados resultam em células esporogênicas chamadas fiálides sendo que estas podem ser cilindricas e hialinas afiladas no ápice, os fialósporos não são septados, cilíndricos hialinos ou levemen te pigmentados.. As colunas verdes de conídios surgem de um micélio branco dando uma aparência de aderência na cultura.

Hammil (1972), citado por SANTOS (1978), definiu as fiálides como células conidiogênicas que produzem pelo menos o seu primeiro conídio entre a extensão apical da célu- 
1a, o qual é liberado pela ruptura da parede celular e observou que as fiālides são geralmente cilíndricas e levemente intumescidas antes de afilarem rapidamente para um estreito ápi ce conidiogênico de 1 micrômetro no máximo. Após um conídio prévio ter sido delimitado por um septo, ele move-se para fora do colo da fiálide e o próximo começa a se formar. As orga nelas penetram nos conídios e os mesmos são delimitados por septos, continuando o processo.

Quanto ao tamanho dos conídios de M. anisopliae, Johnston (1915), citado por SANTOS (1978), refere-se à duas for mas deste fungo, sendo proposto por TULLOCH (1976) a combinação das formas referidas por Johnston, em duas variedades, a variedade minor com conídios de 2,0 a 3,5 micrômetros de comprimento e a variedade major com conídios de 3,0 a 11,9 micrô metros de comprimento.

\subsubsection{MODO DE ACĀO DO M. anisopliae NO HOSPEDEIRO}

Os fungos, de modo geral, agem inicialmente via tegumento e raramente via oral, e vários trabalhos explicam o modo de ação do M. anisopliae sobre diferentes,tipos de hospe deiros como os de GUAGLIUMI et alii (1974), SCHABEL (1976), FER RON (1981), SILVEIRA e MESSIAS (1983) e ALVES (1984).

Segundo ALVES (1984) os conídios de M. anisopliae ao caírem sobre o tegumento do inseto Diatraea sacchara 
lis (Fabr.), germinam quando encontram condiçōes favoráveis de temperatura e umidade. A germinação ocorre dentro do período de 12 a 24 horas e se caracteriza pelo aumento do volume dos conídios e pela formação de um tubo germinativo, o qual possui na sua extremidade, uma porção dilatada, denominada apressó- 1 rio e um grampo de penetração. Estas estruturas têm ação mecâa nica no processo de penetraçāo e nesta fase estão envolvidos dois processos: o físico, representado pela pressão da hifa que rompe as áreas quitinosas do tegumento, e o químico, no qual tomam parte diferentes enzimas, que provocam a histólise do tegumento. A penetração ocorre nrincipalmente nas regiões intersegmentares do corpo do inseto, no período de 24 a 48 horas. Conforme o mesmo autor, após a penetração, in $\underline{i}$ cia-se o processo de colonização do hospedeiro. A hifa penetrante se engrossa e se ramifica através do tegumento e na ca vidade geral do inseto. 0 micélio se quebra, formando pequenos conjuntos de hifas. Durante esta fase, o fungo secreta uma série de toxinas, as quais contribuem para a ocorrência de distúrbios fisiológicos e para o desencadeamento da micose, terminando com a morte do inseto.

Após a morte do inseto, o fungo cresce saprofiticamente no interior do cadáver, recobrindo todos os órgãos e ocupando a ca vidade geral do corpo. 0 inseto torna-se mumificado, não ocorrendo a putreficação dos tecidos em virtude.:da elaboração, pelo fungo, de toxinas de efeito antibacteriano. A colonização do hospedeiro ocorre no período de 76 a 120 horas, dependendo das con 
dições do inseto e do ambiente. A morte do inseto pode ocorrer depois de 96 a 120 horas da inoculação. As hifas começam a emergir pelos espiráculos e pelas áreas intersegmentares do corpo do inseto. A reprodução do fungo se desenvolve depois de 24 a 48 horas da emergência das hifas. Como sintomas da doença podem aparecer manchas no tegumento, falta de apetite e desorientação nos hābitos. 0 inseto torna-se, inicialmen te, coberto por uma massa de micélio de coloração branca e pos teriormente, por um pó esverdeado, representando os conídios que poderão se disseminàrl e entrar em contato com outros hos pede ios, iniciando um novo ciclo da doença.

\subsection{Doenca e seu progresso em uma populacão de insetos}

GAUMANN (1950) definiu doença como um processo dinâmico no qual hospedeiro e patógeno, sem íntima relação com o meio, se influenciam mutuamente do que resultam modificações morfológicas e fisiológicas.

As doenças causadas em insetos segundo VENTURA (1981), podem dividir-se em dois grupos: as enzoóticas, quando ocorrem numa dada região, porém com baixa intensidade e afetando poucos indivíduos, e as epizoóticas, quando se "manifestam com grande intensidade, afetando um grande número de indivíduos ou mesmo toda uma população. 
Segundo TANADA (1963), o progresso de uma doen ça em uma população de insetos pode ser demonstrado por uma curva denominada curva epizoótica, que pode ser cidividida em três fases: pré-epizoótica, epizoótica e pós-epizoótica. A fa se pré-epizoótica se caracteriza por um baixo número de hospe deiros doentes, resultando de focos primários da doença. Esses focos são formados devido a imigrações de insetos doentes ou a partir de estruturas do patógeno que podem permanecer no solo, nos cadáveres, nas plantas ou são trazicas por pássaros, insetos e por outros animais. A fase epizoótica se caracteriza por elevado indice da doença em conseqüência da multiplí cação e disseminação do inóculo produzido nos focos primários. A fase pós-epizoótica se caracteriza pela diminuição do número d insetos atacados em relação à fase anterior.

ALVES (1985) observou que nas condições da região canavieira do Nordeste, os primeiros adultos de Mahanarva posticata (Stal.) aparecem nos meses de março-abril. Após esse período surgem as primeiras cigarrinhas parasitadas pe 10 M. anisopliae (fase pré-epizoótica). O pico da população de adultos se dá nos meses de julho a agosto e a fase epizoótica da doença vái de agosto a meados de dezembro, quando se inicia a fase pós-epizoótica coincidindo com a redução da popula ção da cigarrinha na região. 


\subsection{Fatores oue afetam a ocorréncia de ePizootias de M. anisopliae}

Para que ocorra uma epizootia do fungo M. anisopliae, alguns fatores deverão estar influenciando favoravel mente. Esses fatores são classificados em bióticos e abiótí cos, e o conhecimento da ação dos mesmos sobre o hospedeiro e sobre o patógeno é de suma importância para permitir um prognóstico consistente de uma epizootia ocorrendo naturalmente ou provocada pela introdução de um elevado potencial de inóculo do fungo no ambiente.

Diversos autores como TANADA (1963); FERRON (1978); KISH e ALLEN (1978); FERRON (1981); VENTURA (1981); WEI SER (1982), comentam a necessidade em se obter conhecimentos sobre Epizootiologia,para serem empregados em programas de ma nejo integrado de pragas.

\subsubsection{FATORES BIÓTICOS}

Para que ocorram epizolotias naturais, é necessário que a praga visada seja suscetível ao M. anisopliae e que a população da mesma esteja elevada, favorecendo a formação de um alto potencial de inóculo e uma disseminação mais rāpida do fungo no ambiente (TANADA, 1963; BURGUES, 1981; VENIURA, 1:981; WEISER, 1982; AIJVS, 1985). 
0 hábito e o estágio do inseto hospedeiro devem ser levados em conta, pois conforme a espécie do inseto, a suscetibilidade pode variar segundo esses dois fatores (TANADA, 1963; BURGUES, 1981; MOSCARDI e CORSO, 1981; WEISER, 1982; ALVES, 1985).

Trabalhos como os de TANADA (1963), BURGUES (1981) e ALVES (1985), comentam a importância das migrações de insetos e de sua distribuição espacial nas plantações, porque permitem que a doença atinja outros insetos mais distantes de seu foco primário, ocorrendo assim uma acentuada epizootia.

ALVES (1985) observou a ocorrência anual de uma doença de caráter epizoótico nos canaviais da região Nordeste, disseminada inicialmente pela imigração de adultos de cigarrinha contaminados por M. anisopliae.

Segundo TANADA (1963) e ALVES (1985), os hospe deiros intermediārios podem favorecer os processos de variabí lidade genética dos patógenos, a disseminação e a perpetuação do patógeno, inclusive na ausência do hospedeiro principal.

Quanto às caracterîsticas dos patógenos, são de gran de importância para a ocorrência de epizootias e segundo TANA DA (1963), o patógeno deve apresentar alta virulência e agres sividade, alta capacidade de sobrevivência e alta capacidade de dispersão no ambiente.

A obtenção de isolados ou linhagens de M. anisopliae mais virulentas e agressivas tem siḍo feita "através de bioensaios comparativos por diversos pesquisadores no Bra- 
sil (VILLACORTA, 1980; ALVES, 1982; SOSA GOMEZ, 1983; SOSA GO MEZ e ALVES, 1983; ALVES et alii, 1984c; BORGES, 1985).

A virulência pode ser aumentada através de pas sagens sucessivas sobre o hospedeiro (FERRON, 1978) ou através de engenharia genética provocando-se mutações ou até del cruzamentos entre linhagens do patógeno (PEREIRA et alii, 1982).

SCHAERFFENBERG (1964) demonstra a necessidade de se passar o fungo M. anisopliae pelo inseto hospedeiro de tempos em tempos, para manter a virulência do patógeno quando cultivado em meio artificial por longos períodos de tempo. Este fato foi demonstrado também por MURAYAMA et alii (1982), quando detectaram alterações consideráveis na morfologia e vi rulência do $M$. anisopliae após a 8ạ repicagem em meio de arroz.

SOSA GÓMEZ e ALVES (1983) constataram elevada atividade lipolítica, proteolítica e amilolítica em isolados mais virulentos de M. anisopliae sobre Diatraea saccharalis (F.). Segundo TANADA (1963), a capacidade do patógeno sobreviver no ambiente natural junto ao hospedeiro ou dentro do hospedeiro, pode determinar a freqüência de epizootias nas populações de insetos. Comenta também que, o patógeno pode sobreviver associado a insetos parasitos, predadores e outros animais.

MILNER e LUTTON (1976) reportam que conídios de M. anisopliae podem sobreviver por muitos anos no solo, de preferência em temperaturas variando de 16 a $23^{\circ} \mathrm{C}$. 
OLIVEIRA et alii (1981) concluíram que o M. ani sopliae tem seu potencial de sobrevivência no solo, na forma de conídios, por um período mínimo de 90 dias e que a."taxa de infestação"de $1,41 \times 10^{6}$ conídios viáveis por grama de solo é suficiente para manter este patógeno, de maneira saprofítica, pelo mesmo período de tempo.

ALVES et alii (1984d) trabalhando com o isolado $E_{9}$ de $M$. anisopliae sobre plantas de cana-de-açūcar, deter minaram que $50 \%$ dos conídios aplicados tornaram-se inviáveis decorridas 34,$3 ; 31,5$ e 162,5 horas quando localizados respec tivamente em folhas do ponteiro, folhas superiores e nas bainhas das folhas. Este trabalho foi realizado à uma umidade relativa do ar de $58,9 \%$, temperatura média de $20,7^{\circ} \mathrm{C}$ e não houve precipitação pluviométrica. Caso a época de aplicação fosse chuvosa, o ambiente estaria mais úmido, o que certa mente proporcionaria maior capacidade de sobrevivência.

o fungo M. anisopliae, como outros patógenos, deve possuir alta capacidade de reprodução para favorecer a $\underline{0}$ corrência de epizootias, sendo que esta capacidade pode variar de acordo com os isolados do fungo e com o inseto hospedeirc, levando-se en conta o seu tamanho (KISH e ALLEN, 1978; ALVES et alii, 1982; SOSA GOMEZ, 1983; ALVES, 1985).

KISH e ALLEN (1978) encontraram diferentes médias do número de conídios de Nomuraea rileyi (Farlow) Samson sobre cadáveres de Anticarsia gemmatalis Hübner de diferentes tamanhos, sendo $5,6 \times 10^{8}$ conídios nas lagartas mortas peque- 
nas, $1,5 \times 10^{9}$ conídios sobre as médias e $3,18 \times 10^{9}$ conídios sobre as grandes.

ALVES et alii (1982) determinaram o número de conídios de M. anisopliae produzidos sobre ninfas e adultos da cigarrinha Mahanarva posticata Stal durante a fase epizoótica da doença em lavoura de cana-de-açúcar no Estado de Alagoas, sendo encontrado uma média de $1 \times 10^{8}$ conídios para ninfas do terceiro ao quarto ínstar e $1,4 \times 10^{8}$ conídios para os a dultos. Com base no número de insetos atacados por hectare, con cluíram que é formado um elevado potencial de inóculo $(4,9 \mathrm{~kg}$ de conídios/hectare) que justifica a ocorrência de epizootias anuais na região.

SOSA GOMEZ (1983) ao testar vários isolados de M. anisopliae sobre D. saccharalis, verificou que há diferença entre eles, no que se refere à produção de conídios sobre cadáveres do inseto, sendo que os isolados PL-39, PL-47, PL-51 e PL-48 foram os mais produtivos.

RAMOSKA (1984) demonstra que a capacidade de reprodução está diretamente relacionada à umidade relativa do ar, quanto mais úmido o ambiente, maior a capacidade de repro dução.

Por úitimo, é necessário que o fungo conte com alguns fatores de disseminação dos conídios para favorecer a ocorrência de epizootias, segundo TANADA (1963).

0 mesmo autor diz que a maioria dos entomopató genos é incapaz de atingir o hospedeiro por seus próprios imeios 
e que os agentes físicos de disseminação (vento, água da chuva, orvalho, córregos, etc.') e os agentes biológicos de disse minação (hospedeiros primários, secundários, parasitos, preda dores, mamíferos, aves e o próprio homem através de aplicações de um elevado potencial de inóculo no local) são de gran de importância para que uma epizootia possa ocorrer.

\subsubsection{FATORES ABIÓTICOS}

0 conhecimento da ação dos fatores abióticos so bre os fungos é essenciál para se obter bons resultados a nível de campo. Os estudos sobre esses fatores ainda não são con sistentes,"o que prejudica sobremaneira a eficiência desses pa tógenos no campo.

Os fatores abióticos estão correlacionados com - ambiente e são de grande importância, pois a simples presen ça de um patógeno sobre um hospedeiro suscetível não é condição suficiente para que este seja colonizado (ALVES, 1985).

As condições ambientais que mais influenciam na ocorrência de epizootias de patógenos são: temperatura, umidade relativa, radiação solar, presença de substânciás químicas no ambiente, vento, etc. (TANADA, 1963; GALLI e CARVALHO, $\therefore 1978$; WEISER, 1982; ALVES, 1985).

De acordo com ALVES (1985), a ação dos fatores ambientais é mais pronunciada durante as fases de dissemina- 
ção, germinação e penetração do patógeno, do que durante a fä se de colonização, quando o mesmo está em pleno desenvolvimen to.

No caso do fungo M. anisopliae, os fatores abióticos que basicamente influenciam são temperatura, umidade e radiação solar, sendo que o efeito prejudicial deste último fator (radiação ultravioleta) pode ser amenizado com o $\underline{u}$ so de formulações mais adequadas, que protegeriam o inóculo des sas radiações; também com o emprego, a nível de campo, de isolados virulentos mais resistentes à radiação ultravioleta (AL VES e RISCO, 1983; BORGES, 1985; SÓSA GOMEZ, 1983); e também pode ser amenizado através da aplicação do fungo em horärios adequados (final da tarde e noite).

Neste trabalho procura-se enfatizar a ação da temperatura e umidade sobre o comportamento do M. anisopliae, principalmente sobre a manutenção da viabilidade dos conídios e sobre a conidiogênese, já que são dois requisitos de grande importância para a ocorrência de epizootias.

\subsubsection{Influência da temperatura}

A temperatura é um dos principais fatores abiọ ticos, pois atua sobre o M. anisopliae afetando desde a produ ção em laboratório e armazenamento até a sua aplicação e eficiência a nível de campo, podendo favorecer ou não a ocorrên- 
cia de epizootias.

MASERA (1957) cita que temperaturas, entre 25

e $29^{\circ} \mathrm{C}$, são importantes na patogenicidade porque aceleram o processo de infecção de doenças causadas por fungos sobre o hospedeiro.

De acordo com COCHRANE (1958), a temperatura tem influência no crescimento, germinação e reprodução dos fun, gos e que a faixa favorável para o crescimento da maioria dos fungos é de 25 a $30^{\circ} \mathrm{C}$.

BALFOUR-BROWNE (1960) constatou que, ao inoclilar M. anisopliae em Ostainia nubilalis, as condições ideais para a ocorrência da doença eram de umidade saturada e temperatura em torno de $25^{\circ} \mathrm{C}$, sendo a mínima de $10^{\circ} \mathrm{C}$, a ótima em torno de $25^{\circ} \mathrm{C}$ e a máxima entre 32 e $34^{\circ} \mathrm{C}$.

TANADA (1963) comenta que, em geral, altas tem peraturas aceleram o progresso da doença.

Segundo SCHAERFFENBERG (1964) a influência da temperatura deve ser considerada de acordo com as exigências de cada fase da relação patógeno-hospedeiro. Cita também que - M. anisopliae alcança o seu crescimento vegetativo máximo entre 25 e $30^{\circ} \mathrm{C}$.

CLERK e MADELIN (1965) verificaram que a longe vidade de conídios de M. anisopliae decresce à medida que a temperatura de armazenamento é aumentada de 8 para $25^{\circ} \mathrm{C}$.

LATCH (1965) observou que o crescimento de $M$. anisopliae torna-se muito pequeno abaixo de $7^{\circ} \mathrm{C}$ e acima de 
$35^{\circ} \mathrm{C}$, sendo a faixa ótima entre 25 e $30^{\circ} \mathrm{C}$, sendo que nesta fai xa o fungo apresenta-se, também, altamente patogênico.

Segundo WALSTAD et alii (1970), o ótimo de tem peratura para a germinação de conídios de M. anisopliae, encontra-se na faixa de 25 a $30^{\circ} \mathrm{C}$, quando a umidade relativa do ar se encontra próxima de $90 \%$.

AQUINO (1974) cultivou M. anisopliae em garrafas de Roux contendo arroz cozido e em tubos de cultura contendo batata-dextrose-āgar (BDA) por seis meses, sob temperaturas que variaram de 3 a $10^{\circ} \mathrm{C}$, observando que tanto as cultu ras mantidas sob congelamento como as que permaneceram a $8^{\circ} \mathrm{C}$ durante 6 :meses, paralisaram o crescimento do fungo. Essas culturas após repicadas, apresentaram crescimento normal sem diminuição na conidiogênese e virulência do fungo.

BELL e HAMALLE (1974) estudaram a viabilidade e patogenicidade de M. anisopliae e de outros fungos entomopatogênicos, armazenados em sîlica-gel à temperatura de $-20^{\circ} \mathrm{C}$, sendo que o M. anisopliae manteve a viabilidade e pato genicidade por 36 meses.

BASTOS e MATTA (1976) observaram em seu trabaTho sobre a influência da temperatura na conidiogênese do fungo M. anisopliae, que o ponto ótimo de temperatura foi de $25^{\circ} \mathrm{C}$, o mínimo em torno de $20^{\circ} \mathrm{C}$ e o máximo de $30^{\circ} \mathrm{C}$, sendo que nas temperaturas testadas de 10,15 e $35^{\circ} \mathrm{C}$ não houve conidiogênese.

ROBERTS e CAMPBELL (1977) elaboraram revisão so 
bre a influência da temperatura na germinação, crescimento e conidiogênese de diversos fungos, entre eles o M. anisopleae. Os dados sobre este fungo encontram-se na Tabela 1.

Tabela 1 - Efeito da temperatura "in vitro", sobre a germinação dos conídios, crescimento vegetativo e conidiogênese de Metarhizium ani sopliae (Metsch.) Sorok. (adaptado de ROBERTS e CAMPBELL, 1977).

\begin{tabular}{|c|c|c|c|}
\hline \multirow{2}{*}{ Fase de desenvolvimento } & \multicolumn{2}{|c|}{ Temperatura $\left({ }^{\circ} \mathrm{C}\right)$} & \multirow{2}{*}{ Referência } \\
\hline & Otimo & Suportāvel & \\
\hline \multirow[t]{2}{*}{ Germinação dosconídios } & 25 & - & Clerk e Madelin (1965) \\
\hline & 25 a 30 & 15 a. 35 & Walstad et alii (1970) \\
\hline \multirow[t]{3}{*}{ Crescimento micelial } & 24 a 26 & 10 a 30 & Vouk e Klas, (1932) \\
\hline & 25 a 30 & 10 a 34 & Notini et alii (1944) \\
\hline & 25 a 30 & - & Schaerffenberg (1964) \\
\hline \multirow[t]{3}{*}{ Conidiogênese } & 24 a 26 & - & Vouk e Klas (1932) \\
\hline & 25 a 30 & 10 a 35 & Walstad et alii (1970) \\
\hline & - & 15 a 32 & Notini èt alii (1944) \\
\hline
\end{tabular}

Se gundo FERRON (1978), a temperatura exerce ïnfluênciasi multaneamen te sobre o fungo entọmopatôgeno e sobre o inseto hospedeiro.! Cita que a temperatura ótima para o desenvolvimento do M. ani sopliae está em torno de 27 a $28^{\circ} \mathrm{C}$ em meio nutritivo. Relatou também que, em condiçōes de laboratório, em temperaturas cons 
tantes, o período de incubação da doença está diretamente associado à temperatura e que há uma correlação positiva entre o desenvolvimento da doença no hospedeiro e o aumento de temperatura de 13 para $23^{\circ} \mathrm{C}$. Para temperaturas superiores a esta faixa, a correlação serā negativa.

SANTOS (1978) ao estudar o efeito da temperatú ra sobre o fungo M. anisopliae, verificou que a $37^{\circ} \mathrm{C}$ os conídios tiveram sua germinação inibida, sendo que estes tornaram-se inviáveis após ficarem submetidos por mais de 96 horas nes sa temperatura.

VILLACORTA (1978) ao trabalhar com diferentes isolados de M. anisopliae, verificou que a temperatura ótima foi de $28^{\circ} \mathrm{C}$ e que o desenvolvimento do fungo foi prèjudicado acima de $30^{\circ} \mathrm{C}$ e nulo abaixo de $7^{\circ} \mathrm{C}$.

DOBERSKY (1981) estudando a influência da temperatura e da umidade na infecção de M. anisopliae sobre larvas do besouro Scolytus scolytus, obteve menores tempos para alcançar 50\% de mortalidade da praga à medida que a temperatú ra era elevada de 2 para $20^{\circ} \mathrm{C}$.

Segundo MARQUES et alii (1981) as salas de ge $\underline{r}$ minação dos laboratóríos do IAA/PLANALSUCAR são mantidas a uma temperatura de $26^{\circ} \mathrm{C}$ durante a fase de crescimento e coni diogênese do M. anisopliae, pois esta temperatura se mostrou mais favorável para essas fases de desenvolvimento do fungo. De acordo com ALVES (1982) a temperatura é um dos fatores abióticos de grande importância e atua sobre os patógenos a 
fetando a produção, estabilidade na estocagem e patogenicidade nas condições de campo, ressaltando que o fator temperatura torna-se ainda mais importante, tendo em vista a incapacidade dos patógenos de se protegerem das variações de temperatura através de sistemas fisiológicos.

DAOUST et alii (1982) ao estudarem o efeito da formulação na virulência de conídios de $M$. anisopliae sobre larvas de mosquitos, observaram que o fungo formulado com 0 pó orgânico THIXCIN R manteve a viabilidade em $71 \%$ e a virulência bastante alta, durante um ano de armazenamento na temperatura de $4^{\circ} \mathrm{C}$.

ZIMMERMANN (1982) em seu trabalho sobre o efei to de altas temperaturas, umidade relativa e radiação solar artificial na viabilidade de conídios de M. anisopliae, demons tra que a temperatura média letal pode aumentar à medida que a umidade relativa decresce.

Ao estudarem o efeito da temperatura e umidade relativa sobre a viabilidade e virulência de conídios de M. anisopliae quando armazenados por um período de dois anos, DAOUST e ROBERTS (1983) observaram que à medida que se diminui a temperatura, na: faixa de $370^{\circ} \mathrm{C}$ para $19^{\circ} \mathrm{C}$ para a umidade relativa de $97 \%$, consegue-se manter a viabilidade em até 90\% e também uma alta virulência. Já para a :temperatura de $4^{\circ} \mathrm{C}$, conseguiram manter essas características do fungo em con dições elevadas, somente a $0 \%$ de umidade relativa.

ALVES (1984) verificou que a faixa favorável à 
germinação de conídios de $M$. anisopliae vai de 18 a $36^{\circ} \mathrm{C}$, sen do que a faixa mais favorável é de 25 a $27^{\circ} \mathrm{C}$ em umidades acima de $80^{\circ}$, e que acima de $36^{\circ} \mathrm{C}$, praticamente, não ocorre germinação, porém os conĩdios podem permanecer viáveis até a tem peratura de $40^{\circ} \mathrm{C}$, a partir da qual vão perdendo gradativamente a viabilidade. Relatou também, que, sob condições elevadas de umidade, a reprodução do fungo ocorre na faixa de: $21: a \quad 30^{\circ} \mathrm{C}$ de temperatura.

ALVES e NOGUEIRA (1984) ao estudarem o efeito da temperatura sobre dois isolados de M. anisopliae ( $E_{9}$ e PL-43), concluíram que esses isolados conseguem germinar na faixa de 16 a $36^{\circ} \mathrm{C}$, sendo que abaixo de $16^{\circ} \mathrm{C}$ e acima de $36^{\circ} \mathrm{C}$ a germinação é:nula. Concluíram também que o isolado $E_{9}$ perdeu toda a viabilidade após a sua manutenção por 24 horas a partir da temperatura de $40^{\circ} \mathrm{C}$ e que o isolado $\mathrm{PL}-43$ apresentou $50 \%$ de viabilidade a $400 \mathrm{C}$ e viabilidade nula acima dessa temperatura.

ALVES et alii (1984a) verificando a influência de diferentes temperaturas sobre a patogenicidade do fungo $M$. anisopliae isolado PL-27 sobre lagartas de $D$. saccharalis, ob servaram após seis dias da inoculação do fungo, mortalidades de 95,$1 ; 91,4 ; 87,8$ e $16,6 \%$, respectivamente para as temperaturas de $26,28,30$ e $35^{\circ} \mathrm{C}$. De acordo com este trabalho, veri fica-se que à medida que a temperatura aumentou, a mortalidade do inseto decresceu.

ALVES et alii (1984b) ao estudarem a influên- 
cia do fotoperíodo e da temperatura no desenvolvimento e conidiogênese do $M$. anisopliae, concluíram que dentre as combinações de temperatura e fotoperíodo testadas, a condição mais adequada para a produção deste fungo foi a de $28^{\circ} \mathrm{C}$ de tempera tura e 16 horas de fotoperíodo.

RIBA e MARCANDIER (1984) demonstram que a agres sividade do fungo M. anisopliae sobre os ovos de Ostrinia nubilalis Hübn foi mais elevada na condição de $25^{\circ} \mathrm{C}$ e umidade relativa de $100 \%$

Segundo ALVES (1985), pode-se considerar para efeito de aplicação no campo, a faixa de 20 a $30^{\circ} \mathrm{C}$, como sendo a mais indicada para a maioria dos patógenos conhecidos.

O mesmo autor comenta que, se as temperaturas de produção e armazenamento são fáceis de serem controladas, as temperaturas após as aplicações no campo, são i imposšíveis de serem modificadas.

\subsubsection{Influência da umidade}

A umidade desempenha um papel importante, tanto para o patógeno como para o inseto hospedeiro.

A maioria dos insetos apresenta redução na at vidade e desenvolvimento quando a umidade relativa é inferior a $40 \%$. Já os insetos que vivem no solo são mais afetados pela falta ou excesso de água no solo, que basicamente depende da 
chuva (SILVEIRA NETO et alii, 1976).

Müller-Kögler (1965) citado por FERRON (1977), comenta que os fungos entomopatogênicos penetram caracteristí camente no inseto hospedeiro através do tegumento e por isso atribui uma grande importância à umidade relativa do ambiente para que o processo infectivo das doenças causadas por deuteromicetos como Metarhizium, Beauveria, Nomuraea e Paecilomyces, possa se desenvolver.

Ainda com relação aos fungos, a umidade é essencial, sendo importante para as fases de germinação e penetração, e limitante para a fase de reprodução dos mesmos (ALVES, 1985). Este autor comenta também que a umidade pode influir na espessura da camada de cera dos insetos, tornando-os mais ou menos resistentes aos patógenos.

TANADA (1963) comenta a importância da umidade na ocorrência de epizootias e que fungos como o M. anisopliae necessitam de umidades de 60 a 1:00\% para o seu desenvolvimento, principalmente na germinação dos conídios. Cita também a importância do microclima ao redor do inseto, que pode até ser mais importante que o macroclima, dependendo da vegetação, da capacidade do solo em reter a umidade e outros.

SCHAERFFENBERG . (1964) relatou que altas umidades são mais necessārias na fase de reprodução do fungo M. anisopliae.

CLERK e MADELIN (1965) verificaram que conidios de $M$. anisopliae sobrevivem mais tempo em altas $(75,4 \%)$ ebaixas 
$(0 \%)$ umidades relativas, do que em umidades relativas médias $(33,7 \%)$, sendo constatado esse resultado em todas as temperaturas testadas no experimentc.

Segundo LATCH (1965), a umidade é um dos fatores ambientais que influenciam no mecanismo de patogenicidade do fungo $M$. anisopliae sobre insetos hospedeiros.

WALSTAD e ANDERSON (1971) verificaram que o $M$. anisopliae requer umidade próxima a $92,5 \%$ e temperatura entre 15 e $25^{\circ} \mathrm{C}$ para germinação do conídio, desenvolvimento micelial e conidiogênese.

FERRON (1977) ao estudar a influência da umida de relativa do ar sobre o desenvolvimento da doença causada por Beauveria bassiana (BaIs)Vuillemin sobre adultos de Acanthoscelides obtectus Say, verificou que após 10 dias da inoculação ob teve $100 \%$ de mortalidade dos insetos em todas as umidades tes tadas $(0,35,55,76,92,98$ e $100 \%)$ a $25^{\circ} \mathrm{C}$ de temperatura e 16 horas de fotofase. Constatou também que o processo infeccioso foi acelerado, a medida que a umidade relativa do ar aumen tava. Já o desenvolvimento micelial do fungo e a conidiogênese no.exterior dos cadáveres dos insetos só ocorreu em umidades relativas iguais ou superiores a $92 \%$ e por essa razão ele comenta que as epizootias naturais deste fungo só ocorrem no período chuvoso onde a umidade relativa é elevada.

FERRON (1978) concluiu que umidades relativas do ambiente próximas da saturação, são necessárias para o de senvolvimento de "surtos epidêmicos" da doença, como para a reprodu- 
ção do fungo sobre os cadáveres dos insetos hospedeiros.

KISH e ALLEN (1978) inocularam o fungo Nomuraea rileyi (Farlow) em lagartas da espécie Anticarsia gemmatalis Hübner em diferentes umidades relativas do ar $(90,70$ e $50 \%)$ com temperatura diurna de $32{ }^{\circ} \mathrm{C}$ e temperatura noturna de $21^{\circ} \mathrm{C}$, e observaram que ocorreu $68 \%$ de mortalidade dos insetos nas umidades de 90 e $70 \%$ e que não ocorreu infecção do fungo na u midade de $50 \%$, demonstrando que existe um nível de umidade re lativa do ar entre 70 e $50 \%$ que é limitante para o fungo $N$. rileyi causar infecção em lagartas de A. gemmatalis.

Estes autores incubaram lagartas com 3 a 4 dias depois de mortas nas umidades de 50,70 e $90 \%$ com temperatura diurna de $32^{\circ} \mathrm{C}$ e noturna de $21^{\circ} \mathrm{C}$ e observaram que a $50 \%$ não houve conidiogênese, a 70\% ocorreu conidiogênese parcial e a $90 \%$ a conidiogênese foi total.

DOBERSKY (1981) ao inocular M. anisopliae em larvas do besouro scolytus scolytus sob diferentes umidades relativas do ar $(51 ; 74 ; 86 ; 90 ; 95 ; 97,5$ e $100 \%)$ observou que este fungo causou infecção no inseto em todas as umidades sen do que, com o aumento da umidade relativa, o tempo necessário para matar $50 \%$ da população de insetos (TL50) diminuía.

LINGG e DONALDSON (1981) ao verificarem o efei to combinado da temperatura e umidade, durante 10 dias, sobre a longevi:dade de conídios de $B$. bassiana no solo, concluíram que em todas as umidades relativas testadas $(0,33,52,75$ e 100\%) a sobrevivência dos conídios no solo esterilizado não sofria re 
dução alguma na temperatura de $-15^{\circ} \mathrm{C}$. Para a temperatura de $55^{\circ} \mathrm{C}$ não houve sobrevivência dos conídios em nenhuma umidade relativa. E nas temperaturas intermediärias de 10 e $25^{\circ} \mathrm{C}$, os indices de sobrevivência forma maiores a 33 e $100 \%$ de umidade relativa, principalmente nesta ültima umidade.

ZIMMERMANN (1982) verificou que a medida que a umidade relativa decresce, a temperatura média letal para conídios de M. anisopliae pode aumentar.

DAOUST e ROBERTS (1983) estudaram o efeito do armazenamento prolongado de conídios de M. anisopliae (isolado $E_{9}$ ESMC), em diferentes temperaturas e umidades relativas, sobre a viabilidade e virulência desses conídios. Verificaram que a viabilidade declinou rapidamente a $37^{\circ} \mathrm{C}$ de temperatura, principalmente nos valores intermediários de umidade relatí va $(12,33,50$ e $70 \%)$. Nas temperaturas de 19 e $26^{\circ} \mathrm{C}$, os coní. dios mantiveram por mais tempo a sua capacidade de germinação, sendo este fato mais nítido a $0 \%$ e a $97 \%$ de umidade relativa. A umidade menos favorável a 19 e $260 \mathrm{C}$ foi a de $33 \%$. A sobrevivência dos conídios a $4^{\circ} \mathrm{C}$ foi similar em todas -as umidades relativas, atē três meses de armazenamento, e após isso houve um declínio significativo da viabilidade nos valores acima de $0 \%$ de umidade. Após dois anos na temperatura de $4^{\circ} \mathrm{C}$ e $0 \%$ de umidade relativa, os conádios ainda apresentavam $66 \%$ de viabilidade. A $-20^{\circ} \mathrm{C}$ de temperatura a viabilidade caiu rapidamente (93 para $18 \%$ após seis meses), mas a perda ao final de dois anos não foi total. A melhor combinação de tempe- 
ratura e umidade foi a de $19^{\circ} \mathrm{C}$ e $97 \%$ de umidade que manteve a pós dois anos $90 \%$ de viabilidade dos conídios.

Quanto à virulência, os mesmos autores compara ram conídios que estiveram estocadosnas melhores condições de temperatura e umidade relativa $\left(26^{\circ} \mathrm{C}\right.$ e $97 \%, 19^{\circ} \mathrm{C}$ e $97 \%, 4^{\circ} \mathrm{C}$ e $0 \%$ ) do experimento e observaram que a virulência mais elevada, sobre larvas de mosquitos, foi a apresentada pelos conidios armazenados a $190^{\circ} \mathrm{C}$ de temperatura e $97 \%$ de umidade relativa.

RAMOSKA (1984) trabalhando com B. bassiana em Blissus leucopterus, observou que o fungo conseguiu provocar doença no inseto sob umidades relativas de $30,50,75$ e 100\%, porém, a conidiogênese só ocorreu em ambientes com umidade re lativa de 75 e $100 \%$, demonstrando assim que a capacidade de reprodução está diretamente associada à umidade relativa do ar. Este comentou que em insetos menos esclerotizados,o fungo encontrou maior facilidade de se desenvolver. Comentou também que deve-se considerar a importância do microclima ao redor do inseto sobre o desenvolvimento do-fungo.

RIBA e MARCANDIER (1984), estudando a influência da umidade relativa sobre os fungos $M$. anisopliae e $B$. bas siana, observaram que os conídios de M. anisopliae, :submetidos por 15 dias a 20,25 e $30^{\circ} \mathrm{C}$ de temperatura em umidades re lativas abaixo de $90 \%$, perderam quase toda a sua virulência sobre ovos de Ostrinia nubilalis Hübn. Verificaram que, a medida que a umidade relativa decresce de $100 \%$ para $30 \%$, o tempo 
necessārio para o fungo B. bassiana matar $50 \%$ das lagartas de o. nubilalis aumenta em três dias. Observaram que não ocorreu conidiogênese do fungo $B$. bassiana na superfície externa das lagartas quando submetidas a umidade relativa de $30 \%$.

ALVES (1985) comenta que em dondições de laboratório, não ocorre conidiogênese total do fungo M. anisopliae sobre insetos colonizados e colocados em ambientes com 40 e $60 \%$ de umidade relativa. E em condições de campo, têm se veri ficado que as epizootias estão sempre correlacionadas com alta umidade relativa $(70$ a $100 \%)$, como ocorre com M. aniscpliae sobre cigarrinhas (Homoptera:Cercopidae).

Baseando-se nos trabalhos apresentados, verifi ca-se que a influência deste fator abiótico está intimamente associada à temperatura ambiente e que altos níveis de umidade $(70$ a $100 \%)$ e temperaturas na faixa de 20 a $30^{\circ} \mathrm{C}$ sao neces sárias para ocorrer alta taxa de germinação dos conídios e a ta taxa de reprodução do patógeno.

\subsection{UtilizAÇÃO DE CLIMOGRAMAS}

A Lei da Tolerância Ecológica de Shelfford (1913), citado por SILVEIRA NETO (1976), diz que os organismos apresentam limites ecológicos mínimo e máximo, dentro dos quais se desenvolvem.

A temperatura e a umidade são dois fatores abiōticos que podem ser limitantes para a produção de conídios 
e para a manutenção da viabilidade desses conídios, como foi comentado anteriormente nesta revisão de literatura.

Para a análise da influência conjunta da tempe ratura e umidade, pode-se utilizar de climogramas, que é uma forma clássica de representação do clima que permite, de maneira simples e prática, a comparação entre duas ou mais regiões no tocante às variações climáticas.

Sob o ponto de vista ecológico, o climograma é útil para se evidenciar a possibilidade de desenvolvimento, a dałtação, instalação e expansão de uma espécie nas regiões em estudo.

Para a sua construção, segundo SILVEIRA NETO et alii (1976), são colocados nas abscissas os dados mensais de umidade da região em estudo e nas ordenadas os dados mensais de temperatura da mesma região e a seguir une-se, em ordem cres cente, os doze pontos referentes aos doze meses do ano, formando um polígono próprio de cada região.

Trabalhos interessantes sobre a previsão de ocorrência e zoneamento ecológico de pragas e de zoneamento ecológico de culturas, foram realizados no Brasil.

PUZZI e CAMARGO (1963) realizaram um estudo so bre a possibilidade da adaptação climática da cochonilha orthezia praelonga Douglas nos pomares de citros do Estado de São Paulo, baseando-se em climogramas (termo-higrogramas), com binando temperatura e umidade relativa do ar.

CAMARGO (1966) realizou um trabalho excepcional 
sobre a viabilidade e limitações climáticas para a cultura do milho no Brasil utilizando-se de evapopluviogramas (climogramas adaptados ao balanço hídrico).

Trabalhos de zoneamento ecológico de pragas fo ram desenvolvidos por PARRA (1981) para o bicho-mineiro-do-ca feeiro e por CAMPOS GUEVARA (1983) para a lagarta-da-maçã-do-algodoeiro, ambos no Estado de São Paulo.

SILVEIRA NETO et alii (1986) estabeleceram um zoneamento ecológico preliminar para as cigarrinhas-das-pasta gens no Brasil, através de climogramas adaptados ao balanço hí drico (evapopluviograma).

Após a construção do climograma representativo de uma região em estudo, pode-se correlacioná-1o com o fungo M. anisopliae, traçando-se sobre o gráfico os pontos de tempe ratura e umidade relativa do ar que delimitam as condições $\underline{\text { fa }}$ voráveis e limitantes, tanto para manutenção da viabilidade dos conídios próxima a $100 \%$, como para uma alta produção de conídios.

E evidente que outros fatores, tais como solo, luminosidade, radiação, etc., podem afetar a produção e a via bilidade dos conídios e por conseguinte a intensidade das doen ças. O conhecimento da ação desses fatores podem tambēm servir para a elaboração de zoneamentos mais precisos do fungo M. anisopliae. 


\section{MATERIAL E MÉTODOS}

0 presente estudo foi desenvolvido no Laborató rio de Patologia de Insetos do Departamento de Entomologia da Escola Superior de Agricultura "Luiz de Queiroz", da Universi dade de São Paulo (ESALQ/USP), Piracicaba, Estado de São Pau10

\subsection{Material}

\subsubsection{ISOLADOS DO FUNGO Metarhizium anisopliae}

Trabalhou-se com três isolados, obtidos na coleção do laboratóio citado anteriormente, cuja denominação, procedência original e hospedeiros originais constam na Tabela 2 . 
Tabela 2 - Relação dos isolados de Metarhizium anisopliae utilizados, com suas respectivas denominações, procedências e hospedeiros originais.

\begin{tabular}{lcc}
\hline Denominação & Procedência & Hospedeiro original \\
\hline$E_{9}$ & EMCAPA, Vitória (ES) & Deois flavopicta (Stal) \\
PL-27 & $\begin{array}{c}\text { Fazenda Charles, Mal. Deodo- } \\
\text { ro (AL) }\end{array}$ & $\begin{array}{c}\text { Diatraea saccharalis } \\
\text { (Fabr.) }\end{array}$ \\
PL-43 & $\begin{array}{c}\text { Fazenda Papuā, Usina Peixes, } \\
\text { Fleixeiras (AL) }\end{array}$ & $\begin{array}{c}\text { Mahanarva posticata } \\
\text { (Stal) }\end{array}$ \\
& $\ldots . . .$. & \\
\hline
\end{tabular}

A razão da escolha desses isolados se deve ao fato de terem sido utilizados em ensaios de campo realizados por Instituições de Pesquisa no Brasil, para controle de cigarrinhas-das-pastagens, cigarrinha-da-cana-de-açúcar e broca-da-cana-de-açúcar.

\subsubsection{INSETO UTILIZADO}

Foram utilizadas no experimento, lagartas de $5^{\circ}$ Instar de $D$. saccharalis, provenientes da criação do Laboratório de Controle Biológico do IAA/PLANALSUCAR de Araras, Estado de São Paulo, criadas em dieta artificial de HENSLEY e HAMMOND modificada pelo IAA/PLANALSUCAR (MENDES et alii, 1980). 


\subsubsection{MEIO DE CULTURA}

0 meio de cultura empregado para a purificação e multiplicação dos isolados de M. anisopliae foi o BDA mais antibiótico, cuja composição encontra-se a seguir:

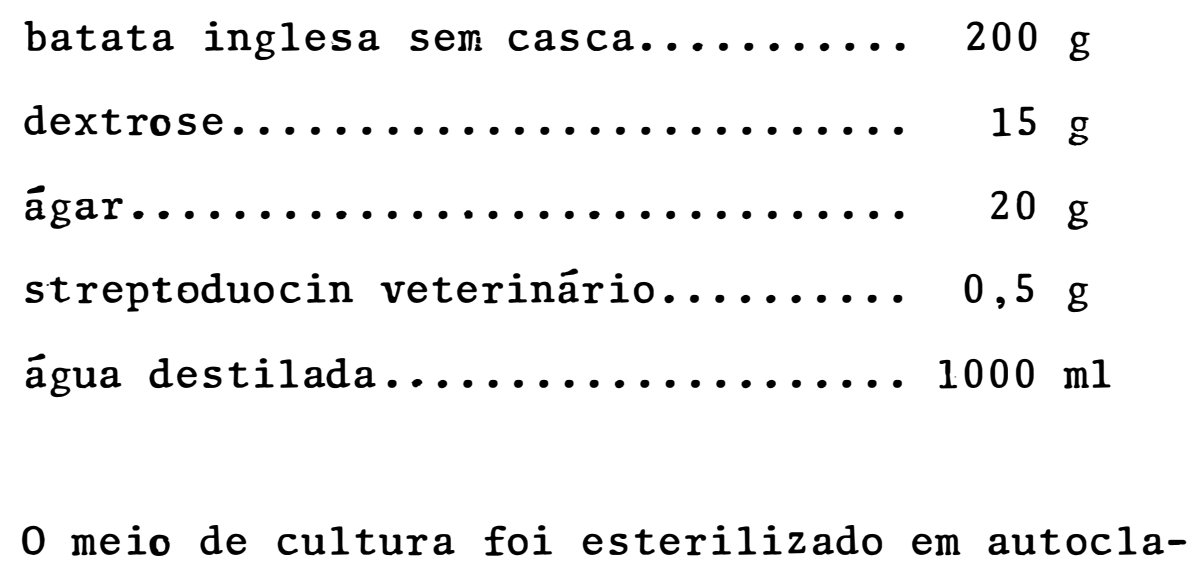
ve a $125^{\circ} \mathrm{C}$ e à uma pressão de 1 atm, durante 30 minutos.

\subsubsection{EQUI PAMENTOS}

- Agitador e aquecedor elétrico, marca FANEM, modelo 258.

- Agitador elétrico, marca ETICA, para homogeinização da suspensão de conídios, com faixa de rotação de 108 até 310 rotações/minuto.

- Balança, marca METTLER, com indicadores digitais, modelo PB-300 .

- Caixas plásticas de $6 \mathrm{~cm}$ de diâmetro por $2 \mathrm{~cm}$ de altura,com tampa telada e espaçadores na base, permitindo que a umida- 
de relativa do ar em seu interior seja a mesma do exterior, para conterem as lagartas nos dessecadores.

- Câmara asséptica de fluxo laminar vertical (capela), marca VECO, modelo VLFS-09, para trabalhos de isolamento, purificação, repicagem, inoculação do fungo e triansfe rêncià de meio de cultura para placas de Petri.

- Câmara de Neubauer, destinada à calibração do inóculo através de contagem de conídios.

- Câmara de plástico de $6 \mathrm{~cm}$ de diâmetro por $2 \mathrm{~cm}$ de altura, para inoculação por imersão do fungo nas lagartas, com tampa e fundo telados, conforme SOSA GÓMEZ (1983).

- Dessecadores de plástico reforçado com tampas rosqueáveis, hermeticamente fechados, com volume interno de $3.500 \mathrm{~cm}^{3}$, contendo cristalizador com soluções de ácido sulfúrico e grade de sustentação das caixas plásticas com tampa telada (Figu ra 1).

- Estufas incubadoras BOD, marca FANEM, modelo 347-G, equipadas com lâmpadas fluorescentes modelo F 15-T 12/LD e lâmpada incandescente de 30 watts (Figura 1 ).

- Microscópio-estereoscópico, marca WILD.

- Microscópio de contraste de fase, marca AMERICAN OPTICAL.

- Microscópio óptico, marca OLYMPUS-CBA 213.

- Termistor digital calibrado, modelo ESALQ/USP.

- Termo-higrômetro calibrado, marca SUNDo e psicômetro, marca INCOTERM .

- Outros materiais: autoclave; estufa para esterilizar a se- 
co; freezer, fogão a gás; microcomputador marca PROLOGICA modelo CP-500; alça de Drigallsky; alça de platina; algodão; água destilada e deionizada esterilizada com e sem espalhante adesivo Tween 80 na concentração de $0,1 \%(\mathrm{v} / \mathrm{v})$; so luções de âcido sulfúrico em difentes concentrações; solução de hipoclorito de sódio a 5\%; Beckers de $500 \mathrm{ml}$; Erlenmeyers de $250 \mathrm{ml}$; termômetros; tubos de cultura com $2,5 . \mathrm{cm}$ de diâmetro e $8 \mathrm{~cm}$ de altura; pipetas; piscetas; pinças; pin céis, etiquetas adesivas; lamparina; plástico transparente elástico marca ROLOPAC; contador manual de conídios; caixas plástjcas com $6 \mathrm{~cm}$ de diâmetro e $2 \mathrm{~cm}$ de altura; lâminas; lamínulas; graxa de silicone; espátula; papel alumínio; placas de Petri com $9 \mathrm{~cm}$ de diâmetro e $2 \mathrm{~cm}$ de altura e colmos de milho (Piranão VD2). 


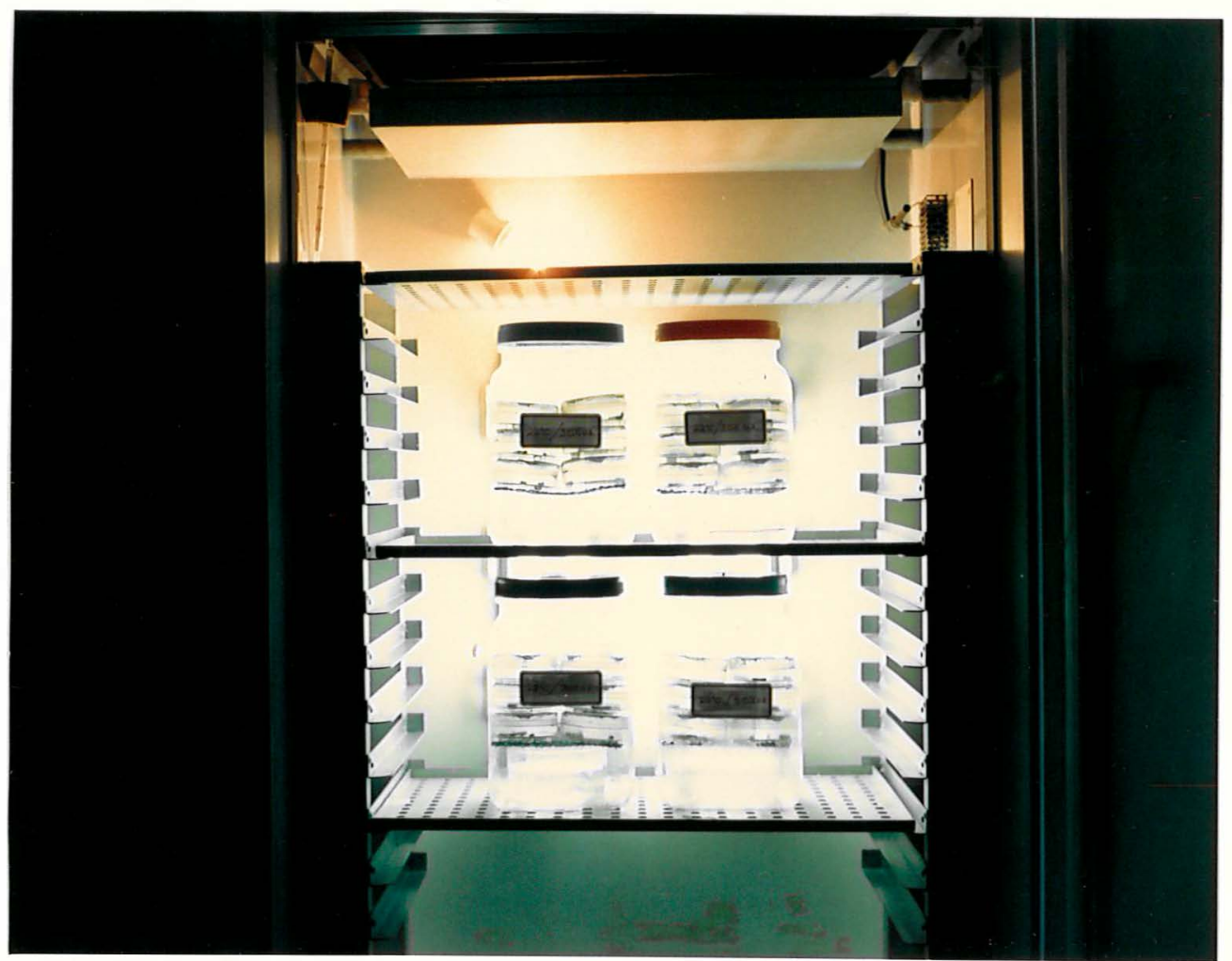

Figura 1 - Estufa incubadora BOD com temperatura e fotofase controladas contendo dessecado res com unidades relativas do ar ajusta das e caixas plásticas com tampa telada em seu interior.

\subsection{MÉtodos}

Utilizando-se dos materiais descritos anterior mente, empregou-se os seguintes métodos para cada fase da pes quisa: 


\subsubsection{CALIBRAÇÃO DA TEMPERATURA NO INTERIOR DOS DESSECADORES}

A calibração da temperatura no interior dos 16 dessecadores utilizados no experimento, sendo quatrodessecadores para cada temperatura $\left(22,26,30\right.$ e $\left.34^{\circ} \mathrm{C}\right)$, foi realizada colo cando-se os mesmos no interior das quatro estufas incubadoras (uma para cada temperatura) com regulagem automática da temperatura desejada e provida de termômetro em seu interior para simples conferência. Alêm disso, introduziu-se em cada dessecador, o sensor de um termistor digital calibrado, de alta precìsão, para refinar o ajuste da temperatura desejada, que demonstrou existir uma variação máxima de $\pm 0,2^{\circ} \mathrm{C}$ para cada temperatura.

\subsubsection{CALIBRAÇÃO DA UMIDADE RELATIVA DO AR NO INTE- RIOR DOS DESSECADORES}

A calibração das diferentes umidades relativas do ar $(30,50,70$ e 90\%) no interior dos 16 dessecadores, já com suas temperaturas calibradas, foi realizada com o auxílio de soluções de ácido sulfúrico $\left(\mathrm{H}_{2} \mathrm{SO}_{4}\right)$ em diferentes volumes e concentrações, conforme a Tabela 3 . 
Tabela 3 - Concentrações e volumes da solução de ácido sulfúrico para con trole da umidade relativa do ar no interior de um dessecador com $3.500 \mathrm{~cm}^{3}$ de volume, em diferentes temperaturas.

\begin{tabular}{cccc}
\hline $\begin{array}{c}\text { Temperatura } \\
\left({ }^{\circ} \mathrm{C}\right)\end{array}$ & $\begin{array}{c}\text { Unidade relativa } \\
\text { desejada }\left(\begin{array}{l}(\%) \\
0\end{array}\right)\end{array}$ & $\begin{array}{c}\text { Concentração da } \\
\text { solução de áci- } \\
\text { do sulfurico(N) }\end{array}$ & $\begin{array}{c}\text { Volume da solução } \\
\text { de ácido sulfüri- } \\
\text { co (ml) }\end{array}$ \\
\hline $22 \pm 0,2$ & 30 & 13,68 & 73 \\
$22 \pm 0,2$ & 50 & 8,69 & 82 \\
$22 \pm 0,2$ & 70 & 5,69 & 138 \\
$22 \pm 0,2$ & 90 & 2,41 & 168 \\
$26 \pm 0,2$ & 30 & $14 ., 27$ & 70 \\
$26 \pm 0,2$ & 50 & 10,20 & 75 \\
$26 \pm 0,2$ & 70 & 5,82 & 140 \\
$26 \pm 0,2$ & 90 & 2,43 & 170 \\
$30 \pm 0,2$ & 30 & 14,27 & 70 \\
$30 \pm 0,2$ & 50 & 9,13 & 78 \\
$30 \pm 0,2$ & 70 & 5,77 & 136 \\
$30 \pm 0,2$ & 90 & 2,35 & 172 \\
$34 \pm 0,2$ & 30 & 14,27 & 70 \\
$34 \pm 0,2$ & 50 & 8,48 & 84 \\
$34 \pm 0,2$ & 70 & 5,03 & 156 \\
$34 \pm 0,2$ & & 2,07 & \\
\hline
\end{tabular}


O fato de se utilizar, para uma mesma umidade relativa do ar, concentrações e volumes de ācido sulfúrico com uma pequena variação, se deve à influência das diferentes tem peraturas, que foi registrada e ajustada com o auxílio de um termo-higrômetro.

\subsubsection{PREPARO DOS INÓCULOS UTILIZAdOS NA PESQUisa}

Os inóculos necessārios para a realização da pesquisa, foram obtidos da seguinte forma, para cada isolado do fungottestado:

Inicialmente foram purificados e mütiplicados em placas de Petri com meio de cultura + antibiótico até a 2a repicagem, incubados durante 9 dias em cada repicagem na temperatura de $26 \pm 0,20^{\circ}$ com 16 horas de fotofase.

Em seguida, retiraram-se os conídios com a àju da de um pincel fino, transportando-os para un Becker com $0.0 \mathrm{ml}$ de água deionizada estéril com espalhante adesivo. Esta suspensão permaneceu por 60 minutos em um agitador elétrico a 200 rotações por minuto, para que houvesse uma perfeita homogeini zação.

Uma parte da suspensão de cada isolado (5 m1) foi retirada para a realização de um teste de viiabilidade dos conídios, pipetando-se $0,5 \mathrm{ml}$ da suspensão para cada placa de Petri com meio de cultura + antibiótico, que foi espalhado com 
auxílio de uma alça de Drigallsky, com um total de 10 repetições por isolado, sendo constatado 24 horas após, $100_{0}^{\circ}$ de via bilidade em todas as repetições dos três isolados. A leitura foi realizada em 100 conídios por repetição, e para serem con siderados germinados, os mesmós deviam apresentar o tubo germinativo, pelo menos com o mesmo comprimento do conídio.

$\mathrm{Na}$ outra parte $(95 \mathrm{~m} 1)$, lagartas de $5^{\circ}$ instar, de $D$. saccharalis ( 20 por isolado) foram imersas durante 6 se gundos ( 2 ciclos de: 3 segundos) e colocadas em caixas plásticas esterilizadas, de $6 \mathrm{~cm}$ de diâmetro por $2 \mathrm{~cm}$ de-altura, com porções de colmo de milho lavadas. Foram incubadas na tempera tura de $26 \pm 0,20^{\circ}$ com fotofase de $16^{\circ}$ horas e umidade relativa próxima da saturação, durante noveldias. 0 alimento era troca do a cada dois dias. Todo esse procedimento foi realizado para se garantir uma alta virulência dos isolados sobre as lagartas a serem utilizadas na pesquisa.

Como os insetos foram submetidos à condições especiais de assepsia e a conidiogênese tinha ocorrido recentemente, foi possível dar um toque com uma alça de platina nos conídios sobre os cadáyeres das lagartas e transportá-los para placas de Petri com meio de cultura + antibiótico, conseguindo-se reisolar e purificar os isolados na 1a repicagem. Es ses conídios foram espalharos nessas placas com auxílio de uma alça de Drigallsky e foram incubadas nas mesmas condições descritas anteriormente, por nove dias, para posteriormente serem retirados com o auxílio de um pincel fino e transportado 
para um Becker contendo $100 \mathrm{ml}$ de água deionizada esterilizada com espalhante adesivo. Essa suspensão foi homogeinizada con forme descrição anterior, onde também se realizou um teste de viabilidade dos conídios como o descrito anteriormente, constatando-se $100 \%$ de viabilidade para os conídios dos três iso1ados.

A suspensão original de cada isolado foi quantificada na câmara de Neubauer, ajustando-a através de diluị ção, na concentração de $5,4 \times 10^{7}$ conídios viāveis/m1 sendo homogeinizada, para finalmente se fazer a inoculação das lagartas a serem utilizadas na pesquisa propriamente dita.

\subsubsection{INOCULAÇÃO E TIPO DE LAGARTA UTILIZADA NA PESQUISA}

Lagartas de $D$. saccharalis no $5^{\circ}$ instar, recém-retiradas da dieta artificial onde foram criadas, sofreram $\underline{u}$ ma lavagem rápida em água déionizada esterilizada sem espa1hante adesivo, para se retirar os resídúos de dieta, impregna dos no corpo do inseto.

Em seguida, realizou-se a inoculação das :mesmas, mergulhando-as na suspensão fúngica $\operatorname{com} 5,4 \times 10^{7}$ conídios viāveis/ml, durante 6 segundos.(2 ciclos de 3 segundos) utilizando-se de uma câmara de inoculação por imersão (CSOSA GOMEZ, 1983). 
Posteriormente, forim colocarjas em caixas plás ticas de $6 \mathrm{~cm}$ de diâmetro por $2 \mathrm{~cm}$ de altura com porções de colmo de milho lavadas, ficando em estufa incubadora (BOD) a $26 \pm 0,2{ }^{\circ} \mathrm{C}$ de temperatura, 16 b.oras de fotofase e umidade relativa próxima da saturação. 0 alimento foi trocado a cada dois dias.

0 número de lagartas inoculadas foi o seguinte: 750 lagartas por isolado para a determinação da produção de conídios sobre cadāveres de lagartas de $D$. saccharalis em diferentes condições de temperatura e umidade relativa do ar e 1000 lagartas por isolado para a determinação da viabilidade dos conídios produzidos sobre cadáveres de lagartas de $D$. sac charalis expostos a diferentes condições de temperatura e umi dade relativa do ar.

Diariamente anotavam-se e se retiravam as lagartas mortas, utilizando-se apenas as que morreram 108 horas (4,5 dias) após a inoculação do fungo, pois é nesse período que ocorre a maior porcentagem de mortalidade, possibilitando a obtenção do número necessário de lagartas para os três isolados e para os diferentes tratamentos.

Essas lagartas mortas selecionadas, foram colo cadas em caixas plásticas (quatro por caixa) de $6 \mathrm{~cm}$ de diâme tro por $2 \mathrm{~cm}$ de altura contendo uma porção de algodão úmido e incubadas a $26 \pm 0,20 \mathrm{C}$ de temperatura, fotofase de 16 horas e $\underline{u}$ midade relativa próxima da saturação, durante 24 horas. Realí zou-se nova seleção de lagartas mortas (192 por isolado para 
a determinação da produção de conîdios e 320 por isolado para a determinação da viabilidade dos conídios), com tamanho e de senvolvimento micelial uniforme (Figura 2), para serem submetidas às diferentes condições de temperatura e umidade relatị va do ar, dentro de caixas plásticas com $6 \mathrm{~cm}$ de diâmetro por $2 \mathrm{~cm}$ de altura, colocadas no interior de dessecadores (Figura 1).

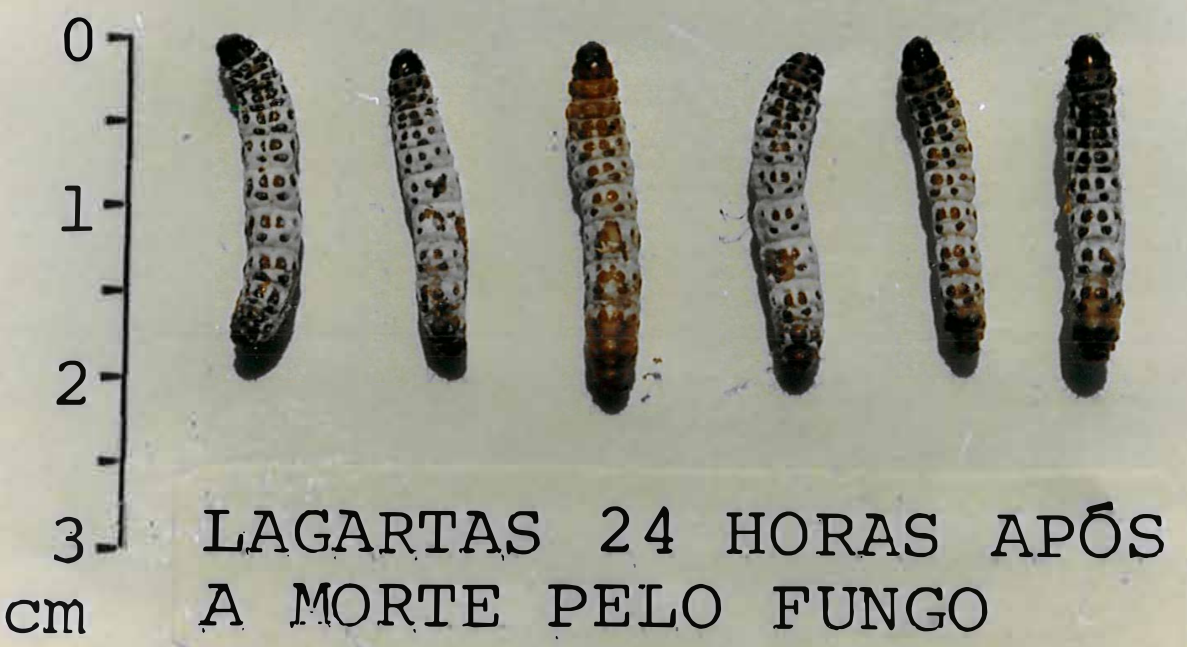

Figura 2 - Aspecto das lagartas, 24 horas após a morte causada por M. anisapliae, incubadas a $26 \pm 0,20$, fotofase de 16 horas e umidade relativa próxima à saturação. 


\subsubsection{POTENCIAL DE INOCULO DOS ISOLADOS DE M. ani- sopliae}

Com o objetivo de se conhecer qual era a quantidade de conídios que efetivamente entrou em contato com is tegumento das lagartas de $D$. saccharalis, logo após a inocula ção com as suspensões dos isolados Eg, PL-27 e PL-43 de M. aní sopliae (conforme descrição do item 3.2.4.), transferiu-se ca da uma dessas lagartas para tubos de cultura contendo $3 \mathrm{ml}$ de água deionizada esterilizada + espalhante adesivo. 0 tubo foi agitado durante 60 minutos a 200 rotações por minuto. Em seguida, avaliou-se o número de conídios suspensos/ml de iágua, com o auxílio da câmara de Neubauer. O número de conídios por lagartas foi obtido, multiplicando-se o valor encontrado na leitura por $3, j a \overline{~ q u e ~ c a d a ~ l a g a r t a ~ f o i ~ l a v a d a ~ c o m ~} 3 \mathrm{~m} 1$ de água. 0 delineamento experimental utilizado foi i inteiramente casualizado, com três tratamentos (referentes aos três isolados) e 10 repetições (10 lagartas por isolado), sendo feita a análise estatística através do teste $\mathrm{F}$ e do teste de Tukey ao nível de $5 \%$ de probabilidade. 


\subsubsection{Determinação da PROduÇÃo DE CONÍdios DE . $M$. anisopliae SOBRE CADÁVERES DE LAGARTAS DE $D$. saccharalis EM DIFERENTES CONDIÇÕES DE TEMPE - RATURA E UMIDADE RELATIVA DO AR}

Com a finalidade de determinar a produção de conídios dos três isolados de $M$. anisopliae ( $E_{9}$, PL-27 e PL-43) sobre cadáveres de lagartas de $D$. saccharalis, obtidos conforme déscrição anterior (item 3.2.4.), submeteu-se os mesmos a 16 condições climáticas diferentes (temperaturas de $22 \pm 0,2$; $26 \pm 0,2 ; 30 \pm 0,2$ e $34 \pm 0,2{ }^{\circ} \mathrm{C}$ associadas a umidades relati vas do ar de $30,50,70$ e $90 \%$ ) durante três diferentes períodos de tempo (12, 24 e 48 horas).

Após cada período de tempo, as caixas plásticas com tampa telada contendo os cadáveres das lagartas, eram reti radas do interior dos dessecadores e eram armazenadas imediatamente em freezer a $-20^{\circ} \mathrm{C}$ de temperatura, para inativação com pleta do desenvolvimento do fungo.

Posteriormente, os cadáveres das lagartas eram retirados do freezer e colocados, individualmente, em tubos de cultura, com $2,5 \mathrm{~cm}$ de diâmetro por $8 \mathrm{~cm}$ de altura, contendo $20 \mathrm{ml}$ de água destilada esterilizada + espalhante adesivo, devidamente etiquetados. Os conídios existentes sobre cada cadáver eram retirados; com o auxílio de um pincel fino den tro do próprio tubo contendo água+espalhante adesivo, dando origem à uma suspensão de conídios que, em seguida, foi agita 
da durante 60 minutos a 200 rotações por minuto.

0 número de conídios por cadáver de lagarta foi obtido com o auxílio de uma câmara de Neubauer, preparando-se duas lâminas por suspensão e efetuando-se a leitura em quatro campos de $1,0000 \mathrm{~mm}^{2}$ de área e $0,100 \mathrm{~mm}$ de profundidade por lâmina. Fêz-se a média das duas lâminas e multiplicou-se por 20 (20 ml de suspensão por tubo contendo um cadáver).

A comparação da produção de conídios ' de $M$. anisopliae durante os três diferentes períodos de tempo $(12,24 \mathrm{e}$ 48 horas) foi realizada, para os três isolados, fixando-se a umidade relativa do ar em $90 \%$ para as quatro temperaturas e fixando-se a temperatura em $26 \pm 0,2{ }^{\circ} \mathrm{C}$ para as quatro umidades relativas.

o delineamento experimental utilizado foi inteiramente casualizado, com quatro repetições. As combinações dos fatores estudados (temperatura, umidade e isolado), num total de 48 tratamentos, foram submetidas ao teste de Tukey ao nível de 5\% de probabilidade. A transformação utilizada para a análise de variância foi $\sqrt{x+0,5}$.

Devido ao interesse nas interações duplas, os desdobramentos destas foram submetidos ao teste de Tukey ao nível de $5 \%$ de probabilidade, tendo-se fixado o tempo de 48 horas, devido ao fato deste ser um tempo suficiente para que ocorra alta produção de conídios e onde os efeitos, benéficos ou prejudiciais, das diferentes temperaturas e umidades são bastante nítidos. 


\subsubsection{DETERMINACÃO DA VIABILIDADE DE CONÍDIOS DE $M$. anisopliae PRODUZIDOS SOBRE CAIDÁVERES DE LAGAB TAS DE D. saccharalis SUBMETIDOS A DIFERENTES CONDIĢÕES DE TEMPERATURA E UMIDADE RELATIVA DO AR}

Com o objetivo de determinar a viabilidade de conídios dos isolados $E_{9}$, PL-27 e PL-43 de M. anisopliae produzidos sobre cadáveres de lagartas de $D$. saccharalis, também obtidos conforme descrição anterior (item 3.2.4.), submeteuse os mesmos a 16 condições climáticas diferentes (temperaturas de $22 \pm 0,2 ; 26 \pm 0,2 ; 30 \pm 0,2$ e $34 \pm 0,2{ }^{\circ} \mathrm{C}$ associadas a umidades re lativas do ar de $30,50,70$ e $90 \%$ ) durante cinco diferentes períodos de tempo ( $12,24,48,72$ e 96 horas).

Após cada período de tempo, as caixas plásticas com tampa telada contendo os cadáveres das lagartas, eram retiradas do interior dos dessecadores e cada um desses cadáveres era esfregado levemente, com auxílio de uma pinça, em $0,1 \mathrm{ml}$ de água sem espalhante adesivo sobre a superfície do meio de culturạ + antibiótico em placa de Petri dando origem à uma pequena suspensão de conídios que foi espalhada na placa com o auxílio de uma alça de Drigallsky. Essas placas foram incubadas a $26 \pm 0,2{ }^{\circ} \mathrm{C}$ de temperatura com fotofase de 16 horas. Após 24 horas, fêz-se a leitura direta no microscópio ótico, do número de conídios germinados, contando-se um total de 100 conídios por repetição de cada tratamento. Para serem 
considerados germinados, os conídios deviam apresentar o tubo germinativo, pelo menos, com o mesmo comprimento do conídio. A comparação da viabilidade dos conídios de M. anisopliae durante os cinco diferentes períodos de tempo $(12,24,48,72$ e 96 horas) foi realizada, para os três isola dos, fixando-se a umidade relativa do ar em $90 \%$ para as quatro temperaturas e fixando-se a temperatura em $26 \pm 0,2{ }^{\circ} \mathrm{C}$ para as quatro umidades relativas.

0 delineamento experimental utilizado foi inteiramente casualizado, com quatro repetições. As combinações dos fatores estudados (temperatura, umidade e isolado), num to tal de 48 tratamentos, foram submetidas ao teste de Tukey ao nível de $5 \%$ de probabilidade.

Devido ao interesse nas interações duplas, os desdobramentos destas foram submetidos ao teste de Tukey ao nível de 5\% de probabilidade, tendo-se fixado o tempo de 96 horas, devido ao fato deste ser um tempo suficiente para que os efeitos, benéficos ou prejudiciais, das diferentes tempera turas e umidades sobre a viabilidade dos conídios sejam mais perceptíveis e acentuados.

\subsubsection{UTILIZAÇĂo DE M. anisopliae COM BASE EM CLIMO- GRAMAS}

Dados mensais da temperatura média e umidade 
relativa do ar média, referentes a 30 anos de observação (1931 a 1960), foram obtidos através de dados e publicaçõès existen tes nos arquivos da Seção de Climatologia Agrícola do Institu to Agronômico de Campinas (BRASIL, 1969 a; BRASIL, 1969b; BRASIL, 1969 c; BRASIL, 1969 d e SAO PAULO, 1986). A partir de ses dados, construiram-se termohigrogramas colocando-se nas abscis sas os dados mensais de umidade da região em estudo e nas ordenadas os dados mensais de temperatura da mesma região e a seguir uniram-se, em ordem crescente, os doze pontos referentes aos doze meses do ano, formando um polígono próprio de ca da região (SILVEIRA NETO et alii, 1976).

Após a construção de vários climogramas, cada um referente à uma região em estudo, os mesmos foram correlacionados com os isolados $E_{9}$, PL-27 e PL-43 de M. anisopliae, traçando-se sobre o gráfico os pontos de temperatura e umidade relativa do ar que delimitam as condições favoráveis que atendem às exigências térmicas e hídricas, para a manutenção da viabilidade dos conídios próxima a $100 \%$ e para uma alta produção de conídios.

Esses pontos que delimitam tais condições foram obtidos através de análises estatísticas realizadas, conforme os itens 3.2.6. e 3.2.7.

Com base nesses conhecimentos, foi possível de terminar a partir de que mês e até quando se pode aplicar o fungo M. anisopliae sobre a praga visada em diferentes regiōes do Brasil, estimando-se que no período favorāvel exista maior 
possibilidade de ocorrência de epizootias, obtendo-se um con trole mais efetivo da praga. Isto fo $i$ demonstrado através de climogramas para três regiōes, com características climáticas diferentes (Belém-PA, Quixadá-CE e Cuiabá-MT). As épocas favo ráveis e desfavoráveis das demais regiões foram apresentadas em forma de figura. 


\section{RESULTADOS E DISCUSSÃO}

\subsection{Potencial DE inóculo dos isolados DE M. anisopliae}

$\mathrm{Na}$ Tabela 4 consta o número de conídios dos isolados $E_{9}$, PL-27 e PL-43 que efetivamente entrou em contato com o tegumento das lagartas de $D$. saccharalis, logo após a imersão das mesmas na suspensão fúngica contendo $5,4 \times 10^{7}$ co nídios/ml, onde se verifica que as quantidades de conídios obtidas fo ram bem próximas, não havendo diferença estatística segundo o teste $\mathrm{F}$ e de Tukey ao nível de $5^{\circ}$ de probabilidade, o que pode ser considerado como um bom resultado, já que aumenta a confiabilidade dos dados de produção de conídios dos três isolados obtidosnas diferentes tempe raturas e umidades relativas, devido a esta confirmação de que cada lagarta ao ser inoculada, recebeu aproximadamente o mesnúmero de conídios. 


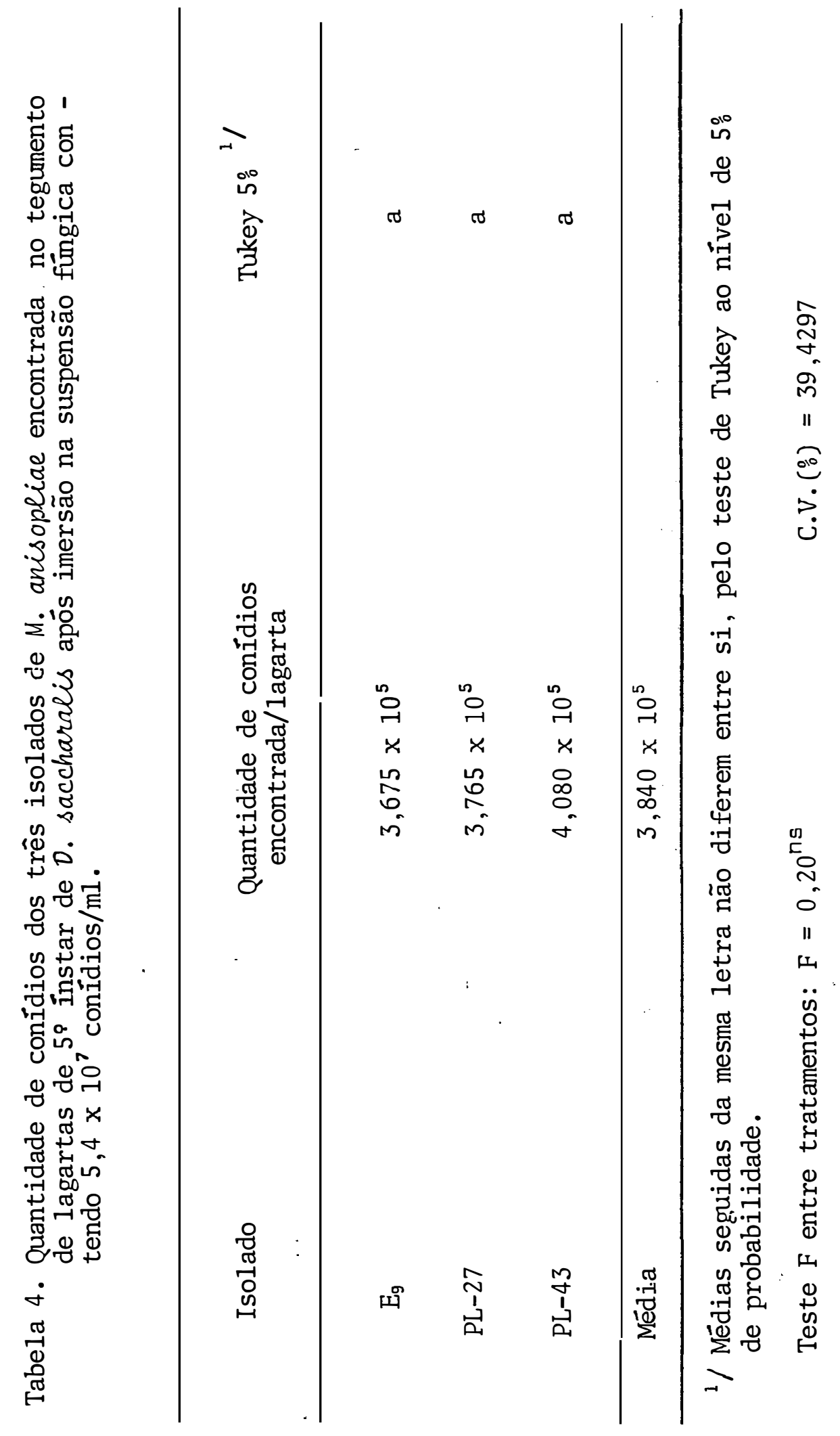




\subsection{DeterminaçÃ da PRODUÇÃO DE CONÍDiOS DE M.anisopliae SOBRE CADÁVERES DE LAGARTAS DE D. saccharalis EM DIFERENTES CONDIÇOES DE TEMPERATURA E UMIDADE RELAT $\underline{I}$ VA DO AR}

0 aspecto do desenvolvimento dos isolados $E_{9}$, PL-27 e PL-43 de M. anisopliae sobre cadáveres de lagartas de $5^{\circ}$ instar de $D$. saccharalis incubados a $26 \pm 0,2{ }^{\circ} \mathrm{C}$ de temperatura e 90\% de umidade relativa do ar durante 12,24 e 48 horas, pode ser observado através das figuras 3,4 e 5 , respectivamente. Após 12 horas de incubação, observa-se que o micélio encontra-se completamente desenvolvido (coloração branca), mas com uma baixa produção de conídios (pigmentação verde clara). Após 24 horas, percebe-se um aumento na produção de conídios, principalmente nos isolados PL-27 e PL-43. Depois de 48 horas de incubação, ocorreu uma alta produção de conídios, para os três isolados testados, o que proporcionou a cobertura total do corpo das lagartas (coloração verde-escura). 


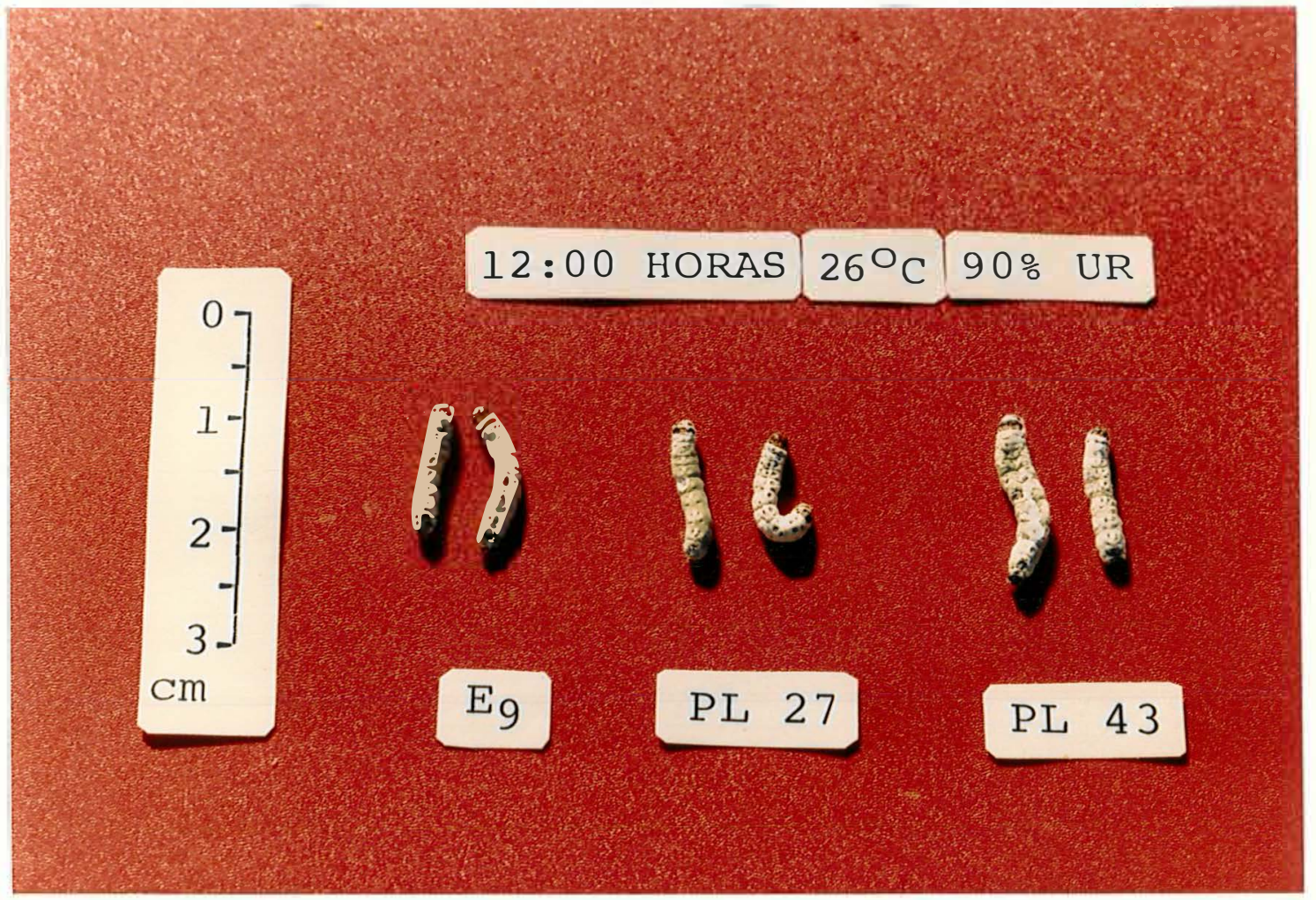

.Figura 3. Desenvolvimento dos isolados $E_{9}$, PL-27 e PL-43 de M. anisopliae sobre cadáveres de lagartas de $D$. saccharalis incubados durante 12 horas a $26 \pm 0,2^{\circ} \mathrm{C}$ de temperatura e $90 \%$ de unidade relativa do ar. 


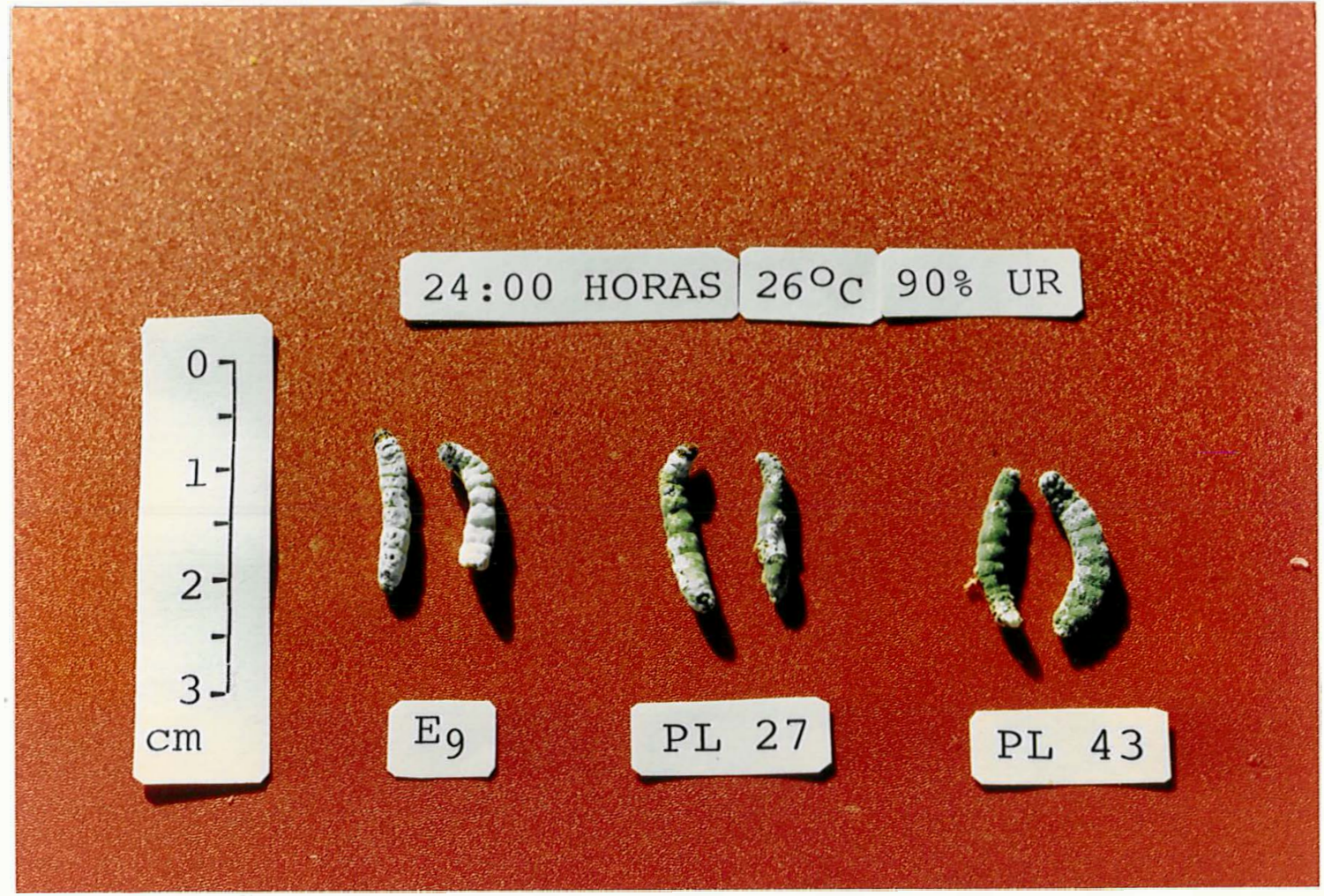

Figura 4. Desenvolvimento dos isolados $\mathrm{E}_{9}, \mathrm{PL}-27$ e PL-43 de M. anisopliae sobre cadáveres de lagartas de D. saccharalis incubados durante 24 horas a $26 \pm 0,2^{\circ} \mathrm{C}$ de temperatura e $90 \%$ de unidade relativa do ar. 


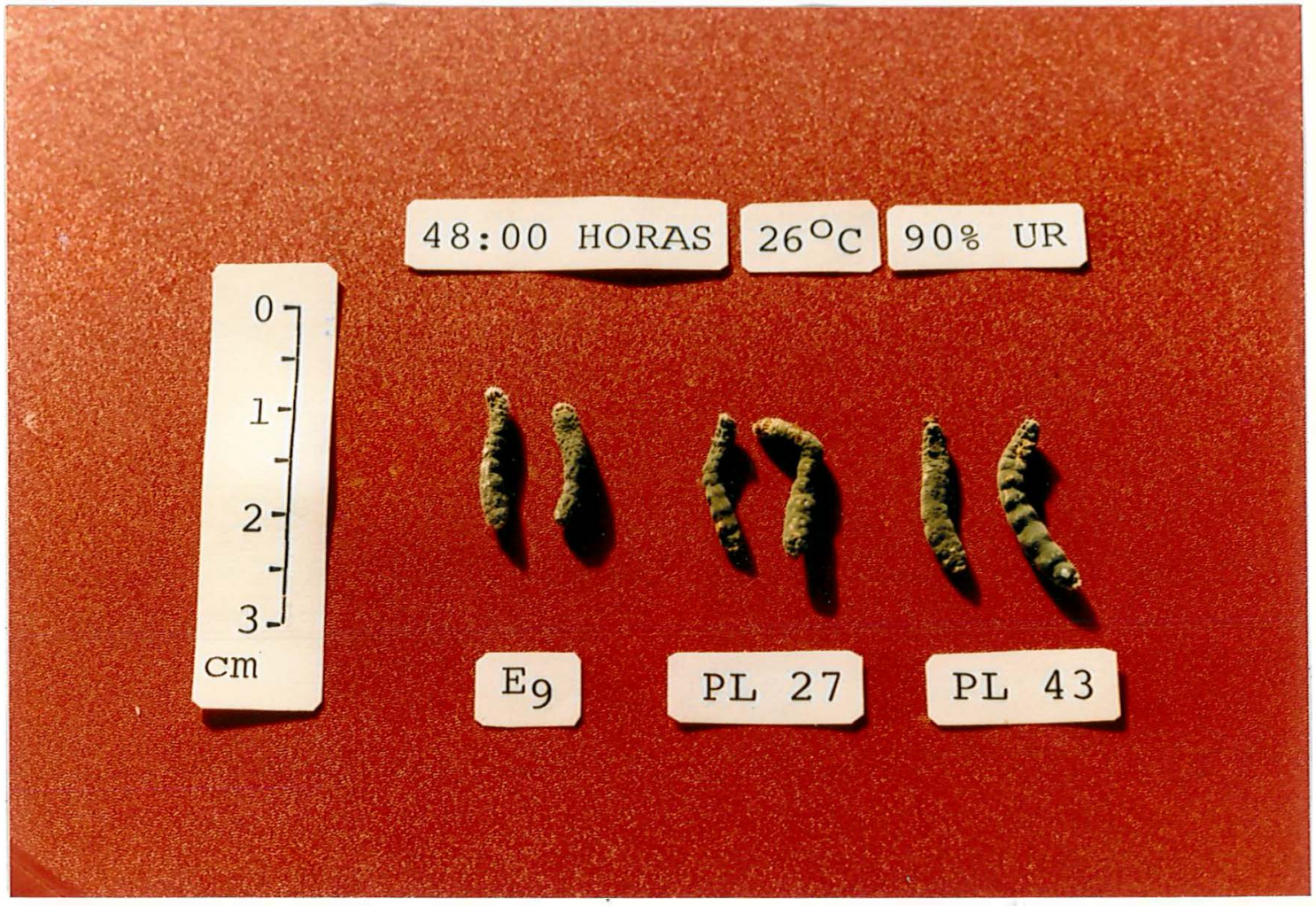

Figura 5. Desenvolvimento dos isolados $E_{9}$, PL-27 e PL-43 de $M$. anisopliae sobre cadâveres de lagartas de saccharalis incubados durante 48 horas a $26 \pm 0,2{ }^{\circ} \mathrm{C}$. de temperatura e $90 \%$ de umidade relativa do ar. 
Os dados da produção de conídios dos isolados $\mathrm{E}_{9}, \mathrm{PL}-27$ e PL-43 de M. anisopliae sobre cadáveres de lagartas de D. saccharalis submetidos durante 12,24 e 48 horas a tem peraturas de $22 \pm 0,2,26 \pm 0,2,30 \pm 0,2$ e $34 \pm 0,2{ }^{\circ} \mathrm{C}$ na umidade re lativa do ar de $90 \%$, encontram-se na Tabela 5 e a representa ção gráfica para o isolado $E_{9}$ pode ser observada na Figura 6 .

Pode-se observar que, com o passar do tempo, a produção de conídios dos três isolados aumentou nas temperatu ras de $22 \pm 0,2,26 \pm 0,2$ e $30 \pm 0,2{ }^{\circ} \mathrm{C}$, ocorrendo uma estabilização dessa produção apenas na temperatura de $34 \pm 0,2{ }^{\circ} \mathrm{C}$ que foi bastante inferior às produções obtidas nas demais temperatu ras.

Observa-se que somente apōs 48 horas os efeitos be néficos ou prejudiciais das diferentes temperaturas testadas sobre a produção de conídios, na umidade relativa de $90 \%$, se mostraram bastante pronunciados, verificando-se o mesmo comportamento para os três isolados, sendo $26 \pm 0,2{ }^{\circ} \mathrm{C}$ a temperatura mais favorável à produção de conídios seguida das temperaturas de $22 \pm 0,2,30 \pm 0,2$ e $34 \pm 0,2{ }^{\circ} \mathrm{C}$. 


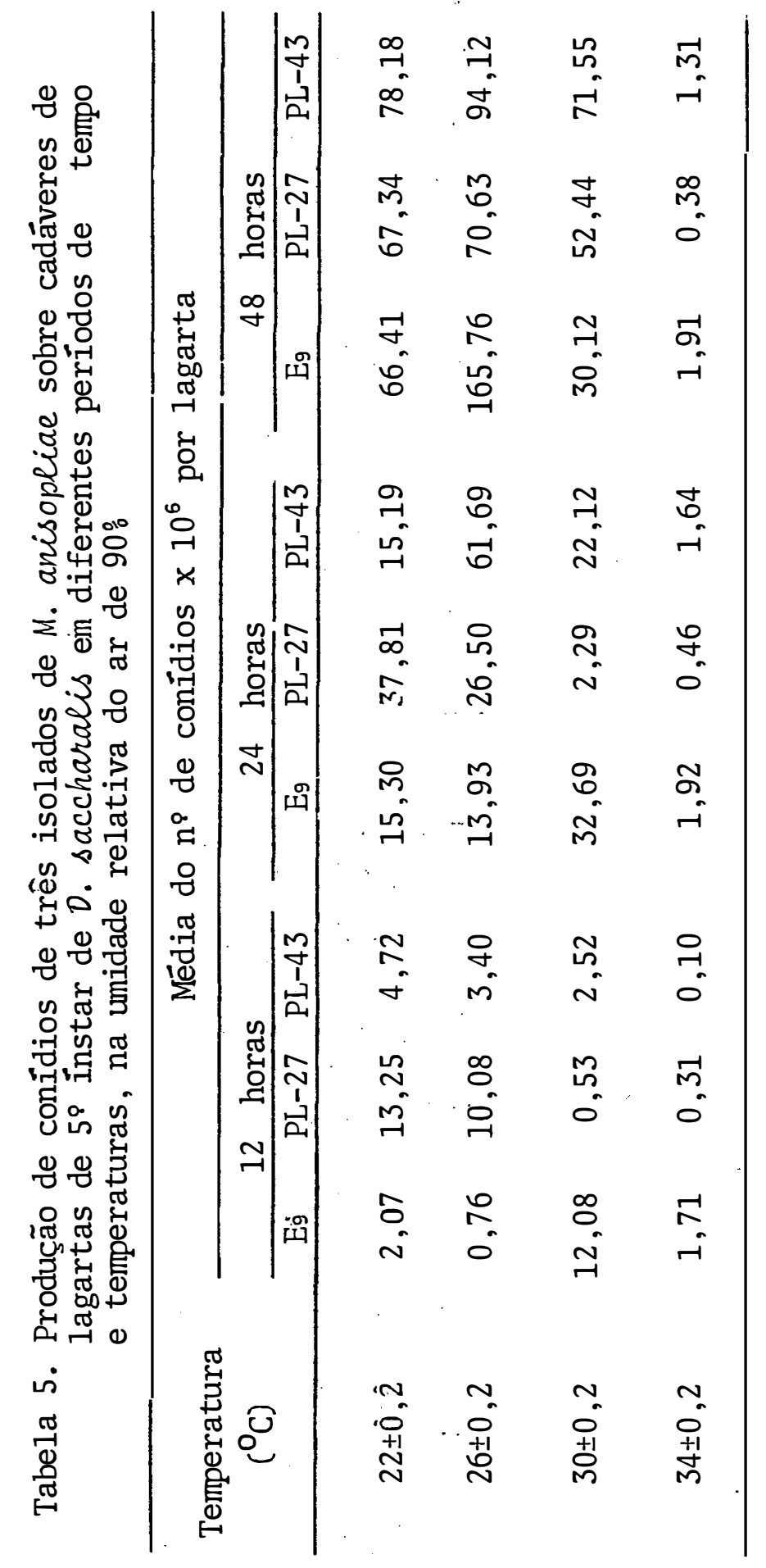




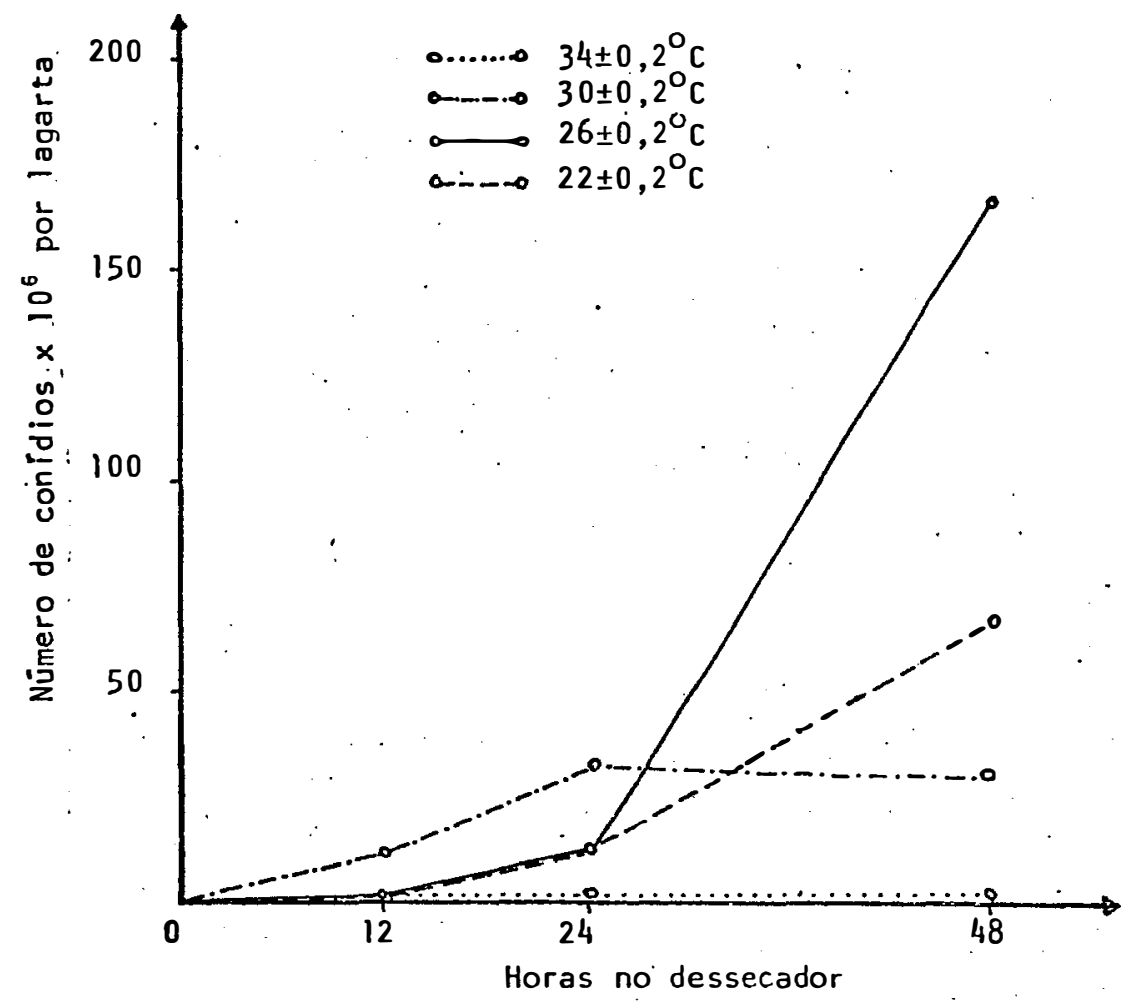

Figura 6. Produção de conídios do isolado $\mathrm{E}_{9}$ de $M$. anisopliae sobre cadáveres de lagartas de $5^{\circ}$ instar de 0 . saccharalis em dife rentes períodos de tempo e temperaturas, na umidade relativa do ar de $90 \%$.

$\mathrm{Na}$ Tabela 6 , pode-se verificar o efeito das umidades relativas testadas $(30,50,70$ e $90 \%)$ sobre a produção de conídios dos isolados $E_{9}, P L-27$ e PL-43 de M. anisopliae em cadáveres de lagartas de $5^{\circ}$ instar de 0 . saccharalis, na temperatura de $26 \pm 0,2{ }^{\circ} \mathrm{C}$ durante diferentes períodos de tempo. 
.63.

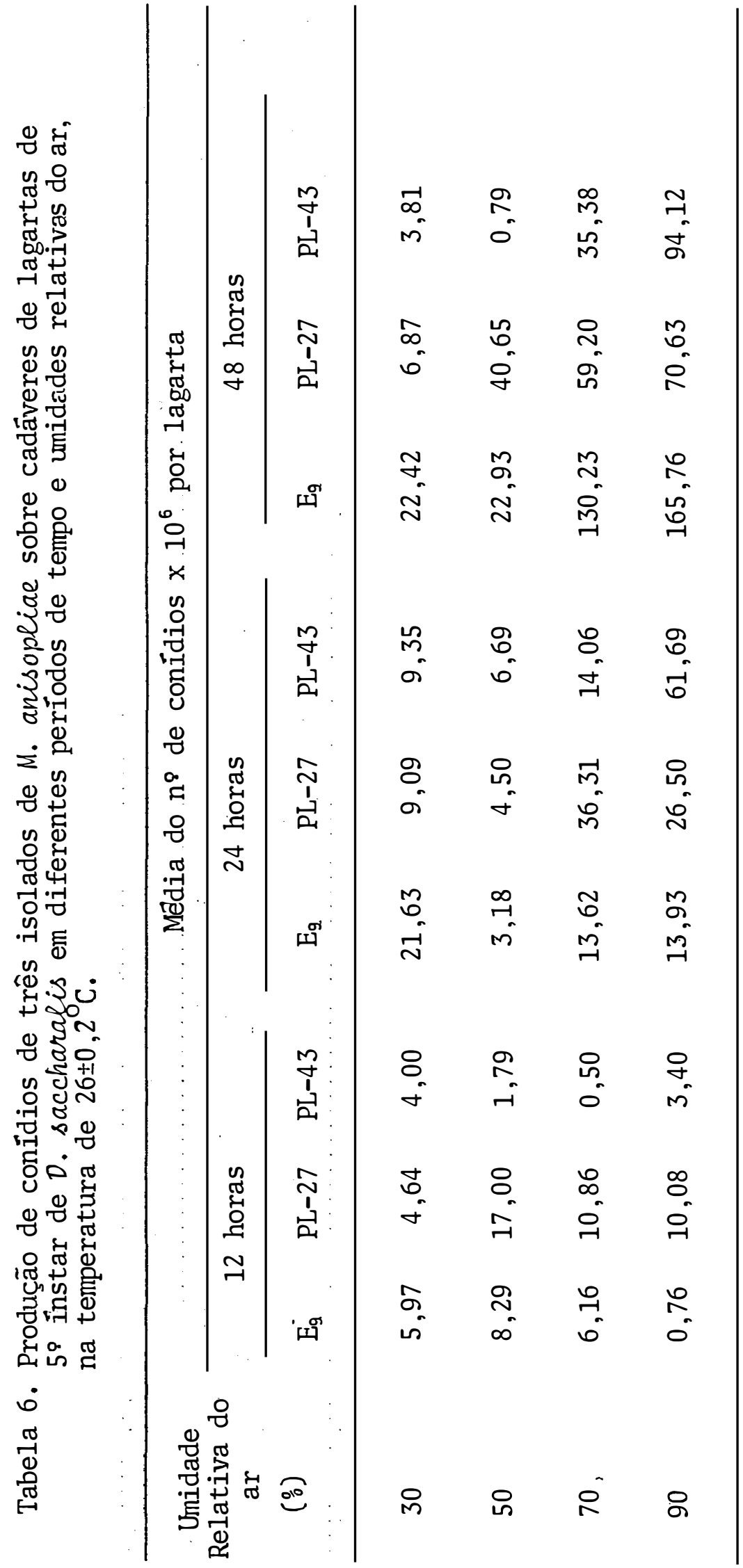


Observa-se que a produção de conídios dos três isolados tambêm aumentou com o passar do tempo, quando os cadáveres das lagartas estavam expostos a umidades de 70 e $90 \%$, e nas umidades relativas mais baixas, 30 e $50 \%$, ocorreu uma certa irregularidade nessa produção, tendo-se obtido produções inferiores às obtidas nas unidades mais elevadas. Isto pode ser melhor visualizado na Figura 7 , tomando-se 0 isolado $E_{9}$ como exemplo.

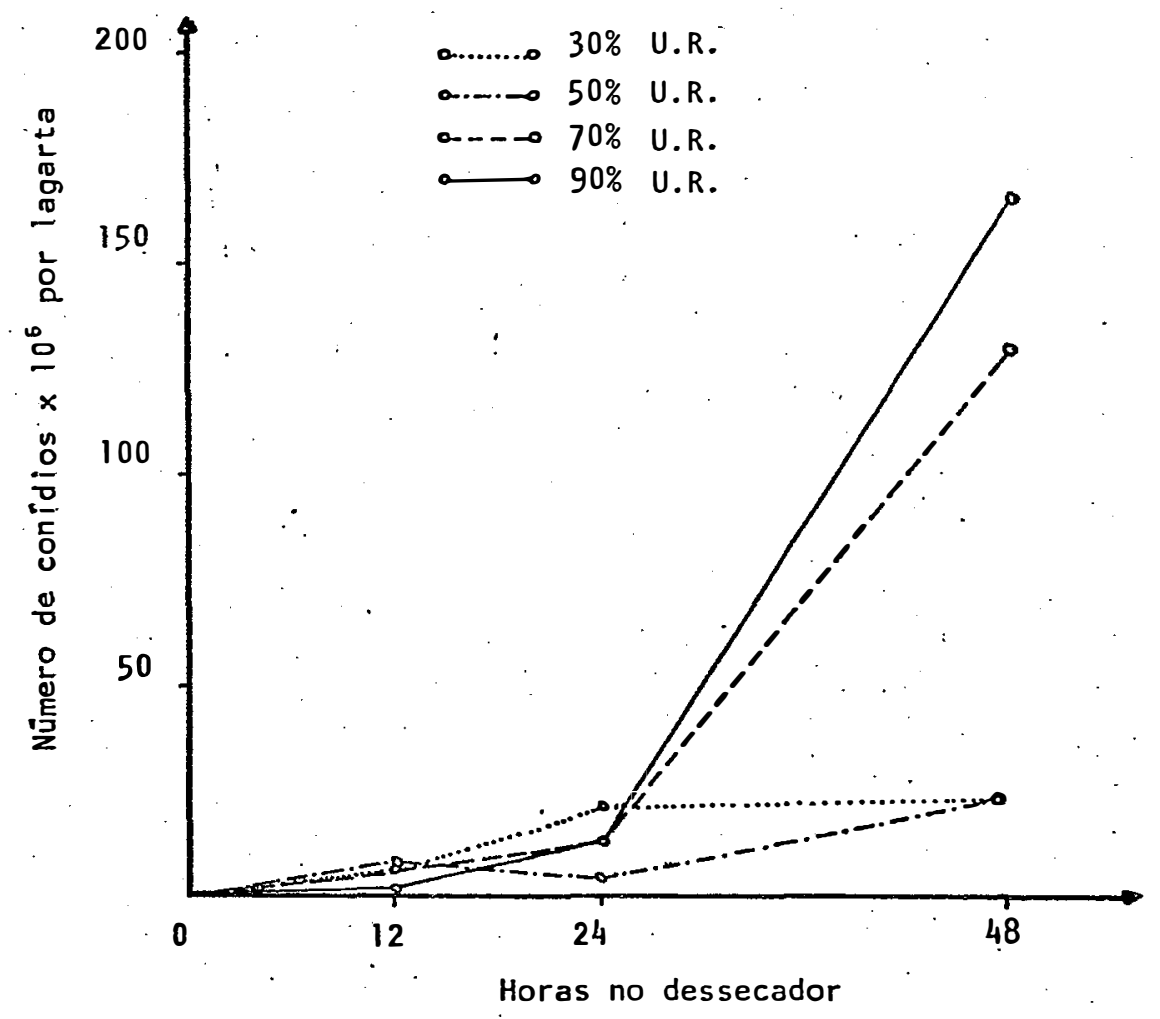

Fịgura 7. Produção de conídios do isolado $E_{9}$ de $M$. anisopliae sobre cadáveres de lagartas de $5^{\circ}$ instar de $D$. saccharalis em diferentes períodos de tempo e umida des relativas do ar, na temperatura de $26 \pm 0,2^{\circ} \mathrm{C}$.

Pode-se verificar que após o tempo de 48 horas, 
a influência das diferentes umidades sobre a produção de coní dios ê mais nítida, proporcionando uma separação das umidades favoráveis $(90$ e $70 \%)$ e das umidades desfavorâveis (50 e $30 \%)$ para a produção de conídios na temperatura de $26 \pm 0,2{ }^{\circ} \mathrm{C}$.

A comparação dos valores médios do número de conídios dos três isolados, produzidos sobre cadáveres de lagartas de 0 . saccharalis incubados durante 48 horas em diferentes condições de temperatura e umidade relativa do ar, pelo teste de Tukey ao nível de 5\% de probabilidade, encontra se na Tabela 7 .

Os resultados de produção de conídios (Tabela 7) evidenciaram que tanto a temperatura como a umidade relat $\underline{i}$ va do ar influenciam no comportamento dos isolados testados, e que esses dois fatores abióticos estão intimamente ligados. Observa-se que, de um modo geral, os três isolados apresentam uma tendência de diminuir a produção quando a temperatura é igual ou superior a $30 \pm 0,2{ }^{\circ} \mathrm{C}$, principalmente em umidades relativas inferiores a $90 \%$.

Procurou-se observar na Tabela 7 , as combinações de temperatura e umidade relativa que proporcionaram al tas produções de conídios para os três isolados ao mesmo tempo. Isso é importante para se determinar as melhores condições à conidiogênese, evitando-se basear somente no comportamento de um isolado.

As produções de conídios observadas nos tratamentos com número de ordem 1 e $2\left(165,768912\right.$ x $10^{6}$ conídios / lagarta e $130,231210 \times 10^{6}$ conídios/lagarta, respectivamente) po 
Totrelu 7. Pralusjo de conídios de trés isolidos de $\mu$. arisopliae sobre cajäveres de lapartas de $5^{0}$ finstar do

\begin{tabular}{|c|c|c|c|c|c|c|c|c|c|c|}
\hline \multirow{2}{*}{$\begin{array}{l}\text { Mirisuro } \\
\text { de } \\
\text { onden }\end{array}$} & & \multicolumn{5}{|c|}{ Trat anento } & \multicolumn{3}{|c|}{$\begin{array}{c}\text { Média do nirrero de conidios } \times 10^{\circ} \\
\text { por laparta. }\end{array}$} & \multirow{2}{*}{ Tukey si" } \\
\hline & & 1 solado & $\begin{array}{l}\text { Terıncratura } \\
\left({ }^{\circ} \mathrm{C}\right)\end{array}$ & $\begin{array}{l}\text { Unidade } \\
\text { do ar }\end{array}$ & $\begin{array}{l}\text { e rel: } \\
\text { r (b) }\end{array}$ & ativg & Transformada '/ & Original & & \\
\hline 1 & & $E_{1}$ & $26 \pm 0,2$ & & 90 & & 12,894530 & 165.768912 & ' & $a$ \\
\hline 2 & & $E_{9}$ & $26 \pm 0.2$ & & 70 & & 11,433775 & 130.231210 & & $a b$ \\
\hline 3 & & $\mathrm{PL}-43$ & $26 \pm 0,2$ & & 90 & & 9,727692 & 94.127985 & & $a b c$ \\
\hline 4 & & $P L-43$ & $22 \div 0,2$ & & 90 & & 8,870273 & 78,181737 & ' & abcd \\
\hline 5 & & $E_{1}$ & $22: 0,2$ & & 50 & & 8,530979 & 72,277605 & & abcde \\
\hline 6 & & $\mathrm{PL}-43$ & $30 \div 0.2$ & & 90 & & 8.488729 & 71,558528 & & abcdef \\
\hline 7 & & PL-27 & $26 \pm 0,2$ & & 90 & & 8,433969 & 70,631841 & & abcdef \\
\hline 8 & & PL-27 & $22 \pm 0.2$ & & 90 & & 8.2365576 & 67.341186 & & $a b c d_{e} f_{R}$ \\
\hline 9 & & $E_{4}$ & $22 \div 0.2$ & & 90 & & 8,180133 & 66,414574 & & abcdefgh \\
\hline 10 & & $E_{n}$ & $30 \div 0,2$ & & 50 & & 8,179770 & 66,408645 & & abcde fgh \\
\hline 11 & & PL-27 & $22 \div 0,2$ & & 50 & & 7,954324 & 62.771267 & . & abcde f $g h i$ \\
\hline 12 & & PL-27 & $22 \div 0,2$ & & 70 & & 7,773982 & 59,934797 & & abcde f ghif \\
\hline 13. & & PL-27 & $26 \div 0,2$ & & .70 & & 7.726591 & 59.200210 & & abcdefghij \\
\hline 14 & & PL-43 & $22 \div 0,2$ & & 70 & & 7.465713 & 55,236864 & & abcde f ghijk \\
\hline 15 & & PL-27 & $30 \div 0,2$ & & 90 & & 7.276207 & 52,443188 & & abcde f 9 h j j kl \\
\hline 10 & & $\mathrm{PL}-27$ & $22+0.2$ & & 30 & & 7,004520 & 48,563300 & & abcdef fhijklı \\
\hline 17 & & $E_{9}$ & $30 \div 0,2$ & & 70 & & 6,560786 & 42.543910 & & bcdef ghijkklm \\
\hline 18 & & PL-27 & $26: 0,2$ & & 50 & & 6.415564 & 40,659456 & & bcde f ghi jklm \\
\hline 19 & . & $P L-43$ & $26: 0.2$ & & 70 & & 5,990396 & 35.384845 & & bcdefghijkln \\
\hline 20 & & $E_{1}$ & $22 \div 0.2$ & & 70 & & 5,647305 & 31,392059 & & bcdef qhijkln \\
\hline 21 & & $E_{4}$ & $30 \div 0.2$ & & 90 & & 5,533782 & 30.122738 & & b乞de f $g^{h i j k l n}$ \\
\hline 22 & & $E_{1}$ & $26 \pm 0.2$ & & 50 & & 4,841356 & 22,938731 & & cdefghijklm \\
\hline 23 & & $E_{1}$ & $26 \pm 0.2$ & & 30 & & 4,788189 & 22.426753 & & cdefghi jklm \\
\hline 24 & & $E_{1}$ & $22 \div 0.2$ & & 30 & & 4,377945 & 18,666406 & & cdef fhijkln \\
\hline 25 & & $\mathrm{PL}-43$ & $22 \div 0.2$ & & 30 & & 4,351995 & 18,439856 & & cdefghijklm \\
\hline 26 & & $P L-43$ & $30 \pm 0.2$ & & 70 & & 4.281402 & 17,830400 & & cdefghijklm \\
\hline 27 & & $\mathrm{PL}-27$ & $30 \div .0,2$ & & so & & 4.278512 & 17,805669 & & cdefphijklm \\
\hline 28 & & PL-27 & $30 \div 0.2$ & & 70 & & 4,207481 & 17,202900 & & cdefphil jklm \\
\hline 29 & & $P L-43$ & $22 \div 0.2$ & & 50 & . & 3,895605 & 14.675741 & & cdefghijklm \\
\hline 30 & & $P L-43$ & $26 \div 0.2$ & & 30 & & 3,810780 & 14,022041 & & cdefphijkim \\
\hline 31 & & $E_{1}$ & $34 \pm 0,2$ & & 70. & & 3,405403 & 11,096767 & & defghijkln \\
\hline 32 & & E, & $30: 0,2$ & & 30 & & 3.206535 & 9,781864 & & defphijklm \\
\hline 33 & & PL-43 & $30 \pm 0.2$ & & 30 & & 2,889180 & 7,847364 & & defghijklm \\
\hline 34 & & PL-27 & $26: 0.2$ & & 30 & & $2 ; 716057$ & 6,876963 & & efghijklm \\
\hline 35 & $*$ & $P L-43$ & $34 \div 0,2$ & & 70 & , & 2,385290 & 5,189608 & & fghijklm \\
\hline 36 & & PL-27 & $30=0,2$ & & 30 & & 2,160953 & 4,169716 & & ghijklm \\
\hline 37 & & $E_{1}$ & $34 \pm 0.2$ & & 30 & & 2,103427 & 3,924405 & & hijklm \\
\hline 38 & & PL-43 & $34 \pm 0.2$ & & 30 & & $1,856315^{\circ}$ & 2.945905 & & $1 j k l m$ \\
\hline 39 & & $\mathrm{PL}-43$ & $34 \pm 0,2$ & & 50 & & 1.723983 & 2,472116 & & $j k \mathrm{~km}$ \\
\hline 40 & & $E_{1}$ & $34 \pm 0.2$ & & 90 & & $1,552706^{\circ}$ & 1,910894 & & klm \\
\hline 41 & & $E_{1}$ & $34 \pm 0,2$ & & 50 & & 1.383616 & 1.414393 & & $\mathrm{klm}$ \\
\hline 42 & & PL-43 & $34=0,2$ & & 90 & & 1.346775 & 1.313803 & & $1 \mathrm{~m}$ \\
\hline 43 & , & $P L-43$ & $30 \div 0.2$ & & 50 & & 1.247635 & 1.056592 & & 20 \\
\hline 44 & & $\mathrm{PL}-43$ & $26+0,2$ & & 50 & & 1,137624 & 0,794188 & & m \\
\hline 45 & & PL-27 & $34,0,2$ & & 30 & & 1,043875 & 0,589676 & & m \\
\hline 46 & & PL-27 & $34 \div 0,2$ & & 90 & & 0.942522 & 0.388348 & & m \\
\hline 47 & & PL-27 & $34 \pm 0,2$ & & 50 & . & 0,928237 & 0,361624 & & $\mathrm{~m}$ \\
\hline 48 & & PL-27 & $34: 0.2$ & & 70 & & 0,891608 & 0.294965 & & m \\
\hline
\end{tabular}

$1 /$ MÉdias transformadas para $\sqrt{x+0,5}$

2/ Mäjias seguidas da mesma letra nāo diferem entre si, pelo teste de hukey ao nivel de $5 /$ de,probabilidade Teste $F$ entre tratamentos: $F=8,4323 \cdots$. C.V. (1) $-42,6478$ 
dem ser consideradas como excelentes, e por essa razão considerou-se como tratamentos que apresentaram alta produção de conídios até o de número $30\left(14,022041 \times 10^{6} /\right.$ lagarta sendo o ụ̂ timo com a letra c).

Pode-se verificar que as produções de conídios mais elevadas dos três isolados foram obtidas em temperaturas como: $26 \pm 0,2{ }^{\circ} \mathrm{C}$ associada às umidades relativas de 90 e $70 \%$; $22 \pm 0,2{ }^{\circ} \mathrm{C}$ associada às umidades relativas de $90,70,50$ e $30 \%$; e $30 \pm 0,2^{\circ} \mathrm{C}$ associada às umidades relativas de 90 e $70 \%$.

Os três isolados se mostraram bastante sensí veis à alta temperatura como $34 \pm 0,2{ }^{\circ} \mathrm{C}$, porém $\mathrm{O}$ isolado, $\mathrm{PL}-27$ foi o que apresentou as menores produções de conídios nessa temperatura, nas quatro umidades relativas testadas.

Através da Tabela 8 , pode-se observar o efeito das diferentes umidades relativas sobre a produção de conídios dos três isolados incubados na temperatura de $34 \pm 0,2{ }^{\circ} \mathrm{C}$, onde se constatou que essa temperatura praticamente inibe o $\underline{\mathrm{e}}$ feito positivo das altas umidades (90 e $70 \%$ ) sobre a conidiogênese, obtendo-se baixas produções de conídios dos três isolados nas quatro umidades relativas. Este resultado coincide com o obtido por VILLACORTA (1978), onde relata que o fungo M. anisopliae tem o seu desenvolvimento prejudicado em tempe raturas acima de $30^{\circ} \mathrm{C}$. Na Tabela 8 , verifica-se que o isolado PL-27 foi o que apresentou os menores índices de produção de conídios em todas as umidades relativas, demonstrando ser o mais sensível à temperatura de $34 \pm 0,2{ }^{\circ} \mathrm{C}$. 
.68.

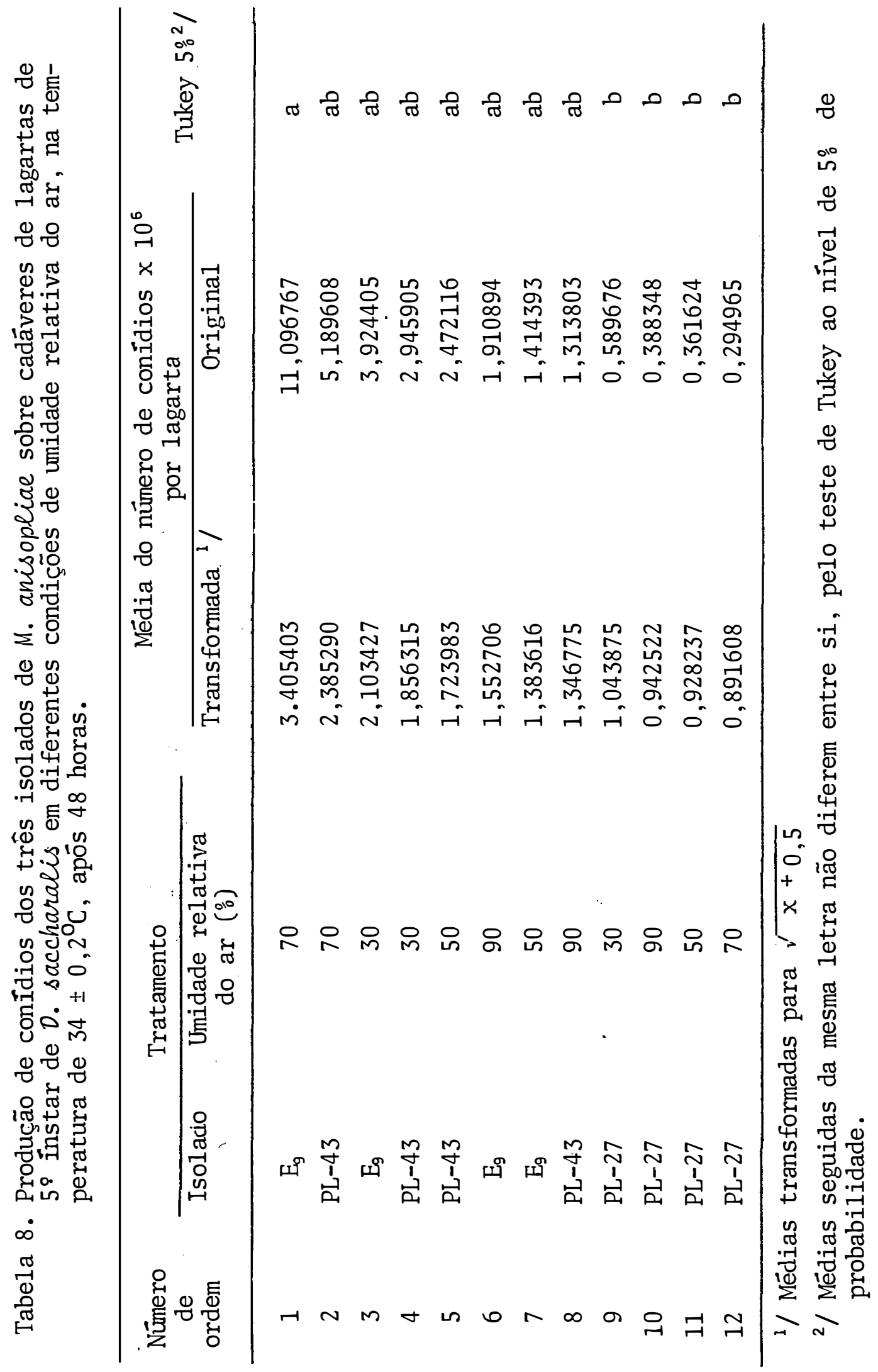


$\mathrm{Na}$ Tabela 9 , pode-se constatar que a temperatura de $30 \pm 0,2^{\circ} \mathrm{C}$ também provoca uma certa inibição da influên cia das diferentes umidades relativas sobre a conidiogênese, mas assim mesmo, observa-se que as umidades mais elevadas (70 e $90^{\circ}$ ) favorecem a produção de conídios dos isolados $E_{9}$, PL-27 e PL-43 sobre cadáveres de lagartas de $D$. saccharalis e que as umidades mais baixas ( 30 e $50 \%$ ) proporcionaram. menores produções, exceto para $O$ isolado $E_{9}$ a $50 \%$ de umidade relativa.

Com relação aos dados da produção de conídios sobre cadáveres de lagartas de $D$. saccharalis incubados $26 \pm 0,2^{\circ} \mathrm{C}$ de temperatura, pode-se constatar através da Tabela 10, que nessa temperatura é onde se evidencia mais nitidamente o efeito das diferentes umidades relativas, sendo portanto a temperatura mais apropriada para ser utilizada em trabalhos de pesquisa que procurem verificar a influência de diferentes umidades relativas sobre a conidiogênese do fungo $M$. anisopliae. Observa-se também que a umidade mais favorável para a produção de conídios dos isolados $E_{9}, P L-27$ e PL-43 foi a de $90 \%$ seguida de $70 \%$. A $50 \%$ e $30 \%$ de umidade relativa a produção decresce bastante. Esses resultados coincidem com os obtidos por SCHAERFFENBERG (1964), por FERRON (1978) e por RAMOSKA (1984), os quais relatam que altas umidades são neces sárias na fase de reprodução do fungo $M$. anisopliae.

0 aspecto do desenvolvimento do isolado $E_{9}$ de M. anisopliae sobre cadáveres de lagartas de $D$. saccharalis in cubados durante 48 horas na temperatura de $26 \pm 0,2^{\circ} \mathrm{C}$ e em dife 


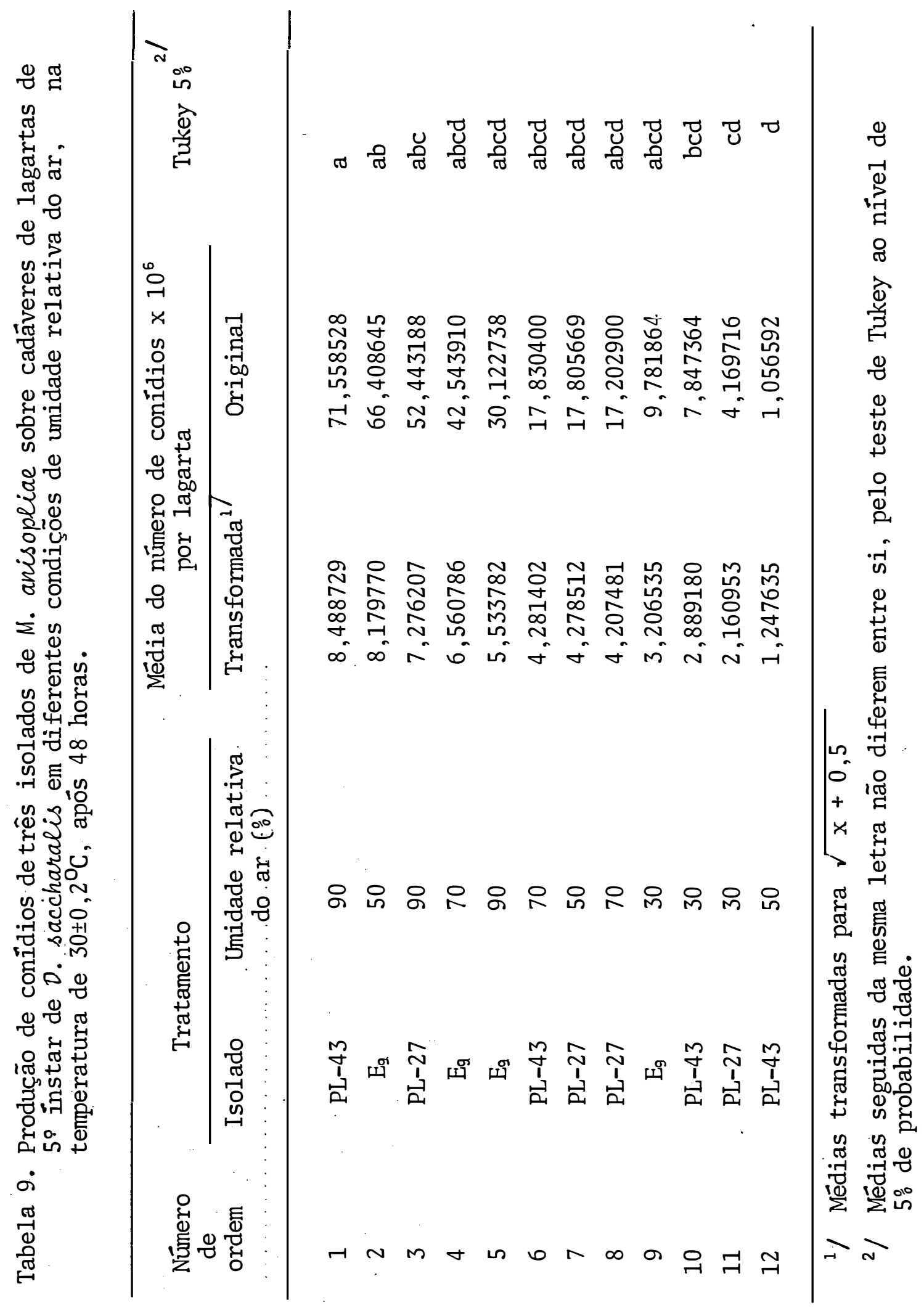




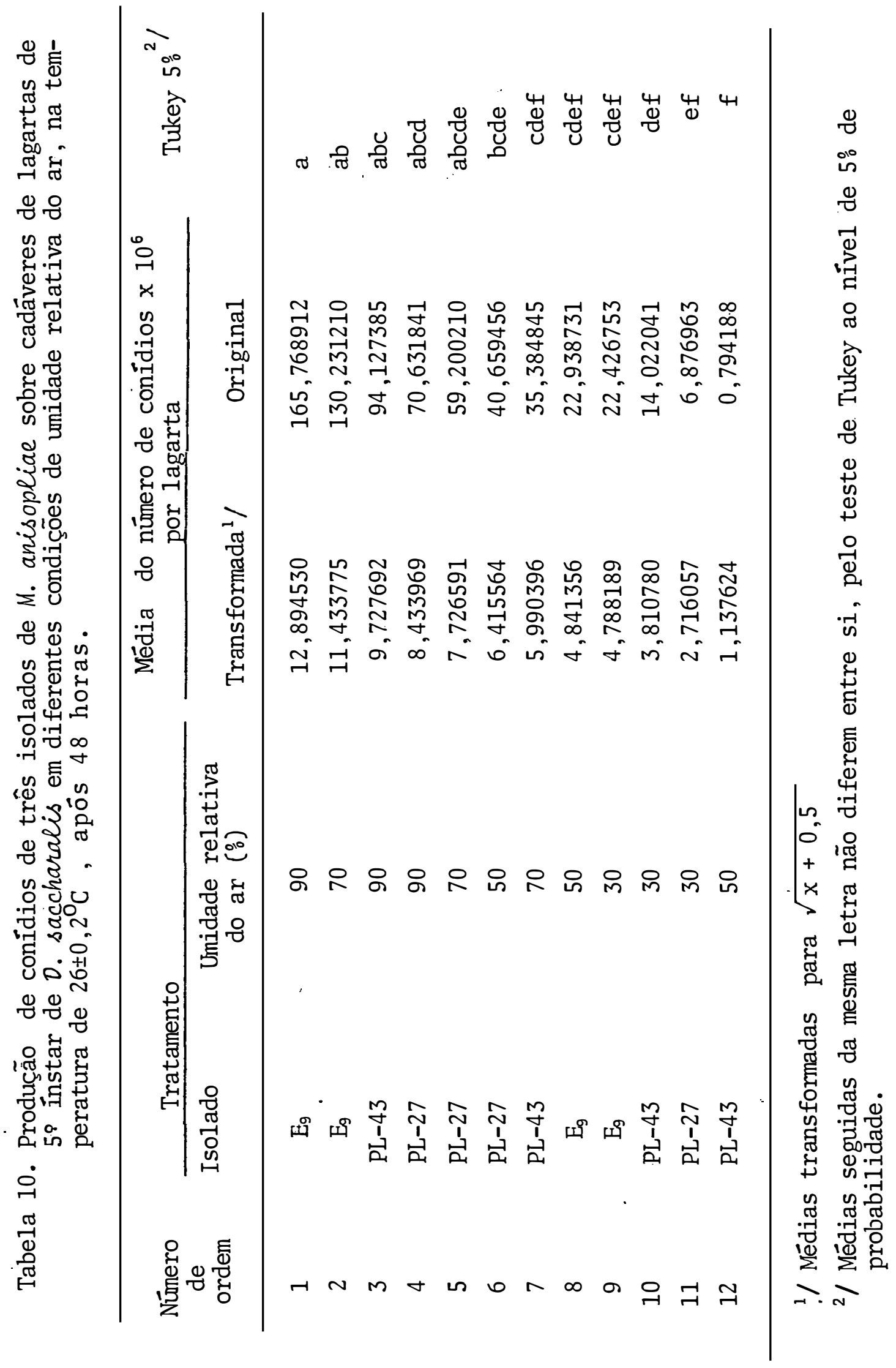


rentes umidades relativas, pode ser visto na Figura 8 , onde se observa perfeitamente que, a medida que a umidade relativa se eleva, a produção de conídios também aumenta.

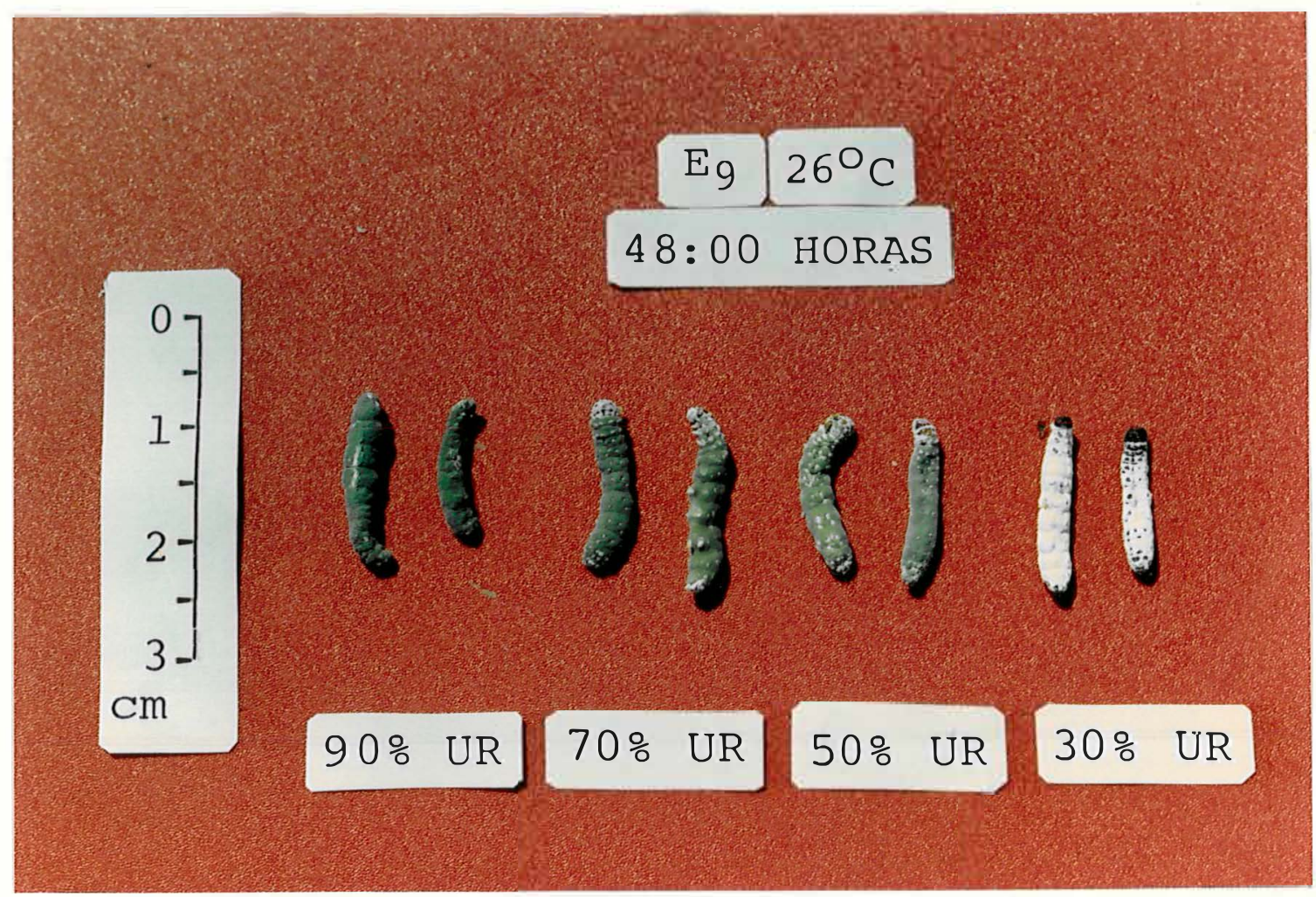

Figura 8. Desenvolvìmento do isolado $E_{9}$ de $M$. anisopliae. sobre cadáveres de lagartas de $D$. saccharalis incubados durante 48 horas na temperatura de $26 \pm 0,2^{\circ} \mathrm{C}$ em diferentes umidades relativas do ar.

Us dados referentes à produção de conídios dos isolados $E_{9}$, PL-27 e PL-43 sobre cadáveres de lagartas de D. saccharalis incubados em diferentes umidades relativas na temperatura de $22 \pm 0,2^{\circ} \mathrm{C}$ encontram-se na Tabela 11 . Observa-se que não houve diferença significativa entre as médias, através 


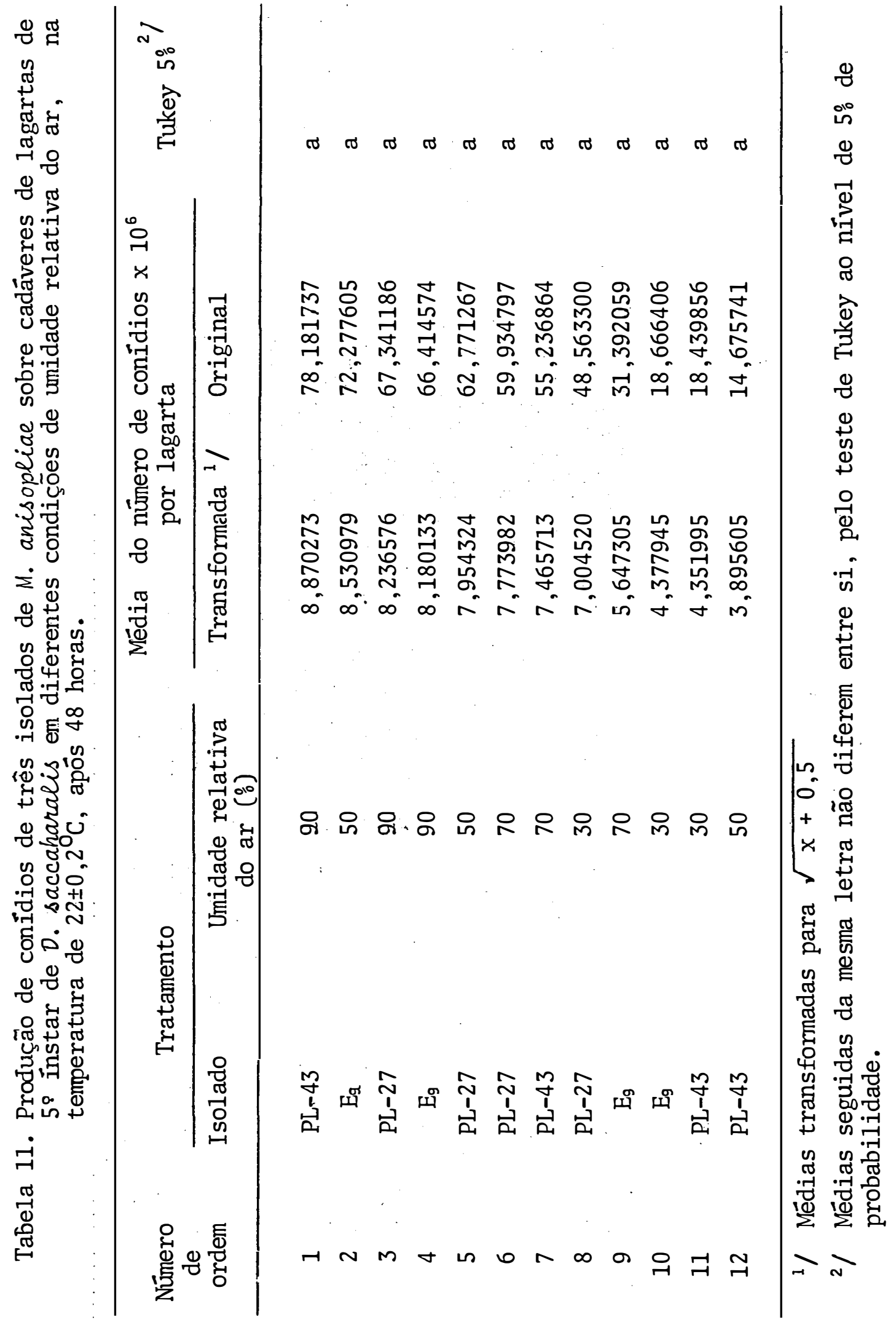


do teste de Tukey ao nível de $5 \%$ de probabilidade, e que todas as condições climáticas proporcionaram alta produção de conídios (acima de $14,022041 \times 10^{6}$ conídios/lagarta) nos três isolados de M. anisopliae. Mas pode-se perceber uma leve tendência da produção de conídios diminuir, a medida que a umida de relativa decresce. O fato de não ter havido diferença esta tística entre as produçōes de conídios nas diferentes umidades, talvez possa ser atribuído ao efeito da temperatura de $22 \pm 0,2^{\circ} \mathrm{C}$. Essa temperatura pode amenizar o efeito prejudicial das baixas umidades relativas. Temperaturas iguais ou superiores $26 \pm 0,2^{\circ} \mathrm{C}$ parecem provocar uṇa desidratação do micélio, impe dindo a formação dos conidióforos e dos conídios. Fica evidenciado, portanto, que a influência das diferentes umi dades relativas do ar sobre a produção de conídios dos isolados, $E_{9}$, PL-27 e PL-43 é dependente da temperatura ambiente.

As médias da produção de conídios dos isolados E9, PL-27 e PL-43 sobre cadáveres de D. saccharalis incubados em diferentes temperaturas na umidade relativa constante de 90\% encontram-se na Tabela 12 , onde se verifica que a tempera tura de $26 \pm 0,2{ }^{\circ} \mathrm{C}$ foi a mais favorável à conidiogênese de todos os isolados $\left(E_{9}=165,768912 \times 10^{6} \quad\right.$ conídios/lagarta,

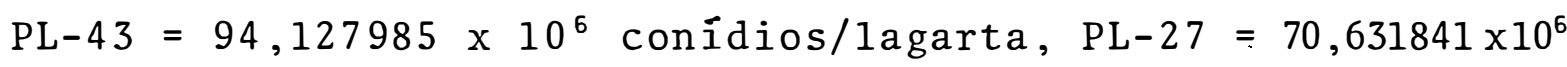
conídios/lagarta), porém suas médias não diferiram significativamente das médias obtidas pelos três isolados na temperatura de $22 \pm 0,2{ }^{\circ} \mathrm{C}$. 


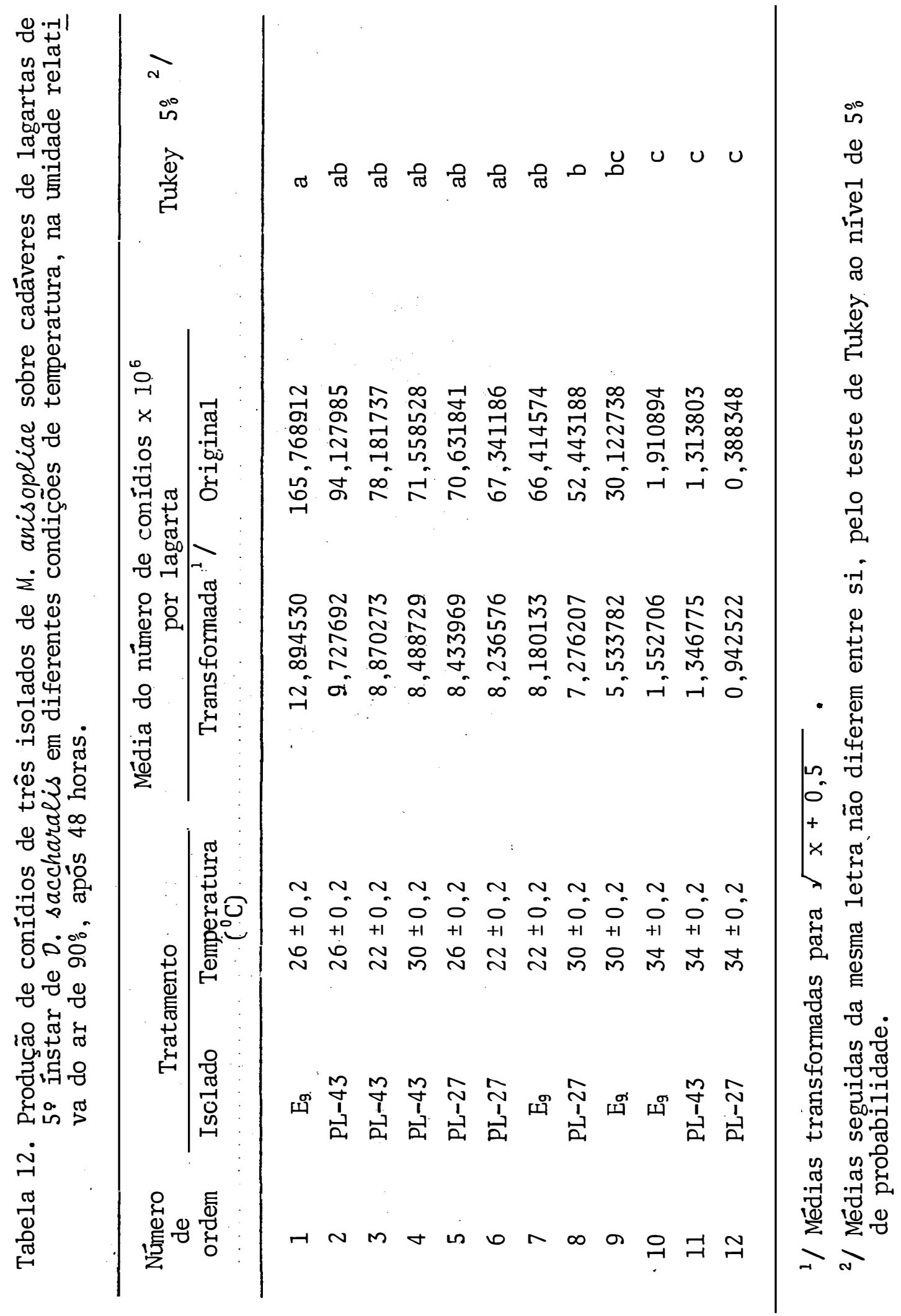


$\mathrm{Na}$ temperatura de $30 \pm 0,2^{\circ} \mathrm{C}$, as médias de produção de conídios também foram elevadas, sendo que apenas os isolados PL-27 e E9 tiveram suas produções diferentes das observadas no isolado $E_{9}$ a $26 \pm 0,2{ }^{\circ} \mathrm{C}$, que pode ser considerada excelente. A temperatura de $34 \pm 0,2{ }^{\circ} \mathrm{C}$ foi prejudicial à uma alta produção de conîdios.

Todos os resultados obtidos na umidade relativa de $90 \%$ coincidem com os do trabalho de BASTOS e MATTA (1976), onde relatam que o ponto ótimo de temperatura para a conidiogênese foi de $25^{\circ} \mathrm{C}$, o mínimo em torno de $20^{\circ} \mathrm{C}$ e o máximo de $30^{\circ} \mathrm{C}$, e também com a recomendação técnica de MARQUES et alii (1981), os quais indicam a temperatura de $26^{\circ} \mathrm{C}$ como a mais favorável para o crescimento e conidiogênese do fungo M.anisopliae. Através da Figura 9, pode-se observar o aspecto da produção de conídios do isolado $E_{9}$ sobre cadáveres de broca-da-cana-de-açúcar incubados por 48 horas na umidade relativa de $90 \%$ em diferentes temperaturas, onde percebe-se uma intensa conidiogênese a $26 \pm 0,2{ }^{\circ} \mathrm{C}$ (verde escuro) e a $22 \pm 0,2^{\circ} \mathrm{C}$. $\mathrm{Na}$ temperatura de $30 \pm 0,2^{\circ} \mathrm{C}$ a cobertura do corpo da lagarta não foi total (verde claro) e a $34 \pm 0,2^{\circ} \mathrm{C}$ não se detecta, através deuma observação convencional a ocorrência de conidiogênese, a qual pôde ser quantificada na câmara de Neubauer; após a lava gem das lagartas.

Verifica-se que a umidade relativa de $90 \%$ pode ser indicada para ser fixada em testes onde se procura determinar somente o efeito de diferentes temperaturas sobre a pro 
dução de conídios de isolados de M. anisopliae.

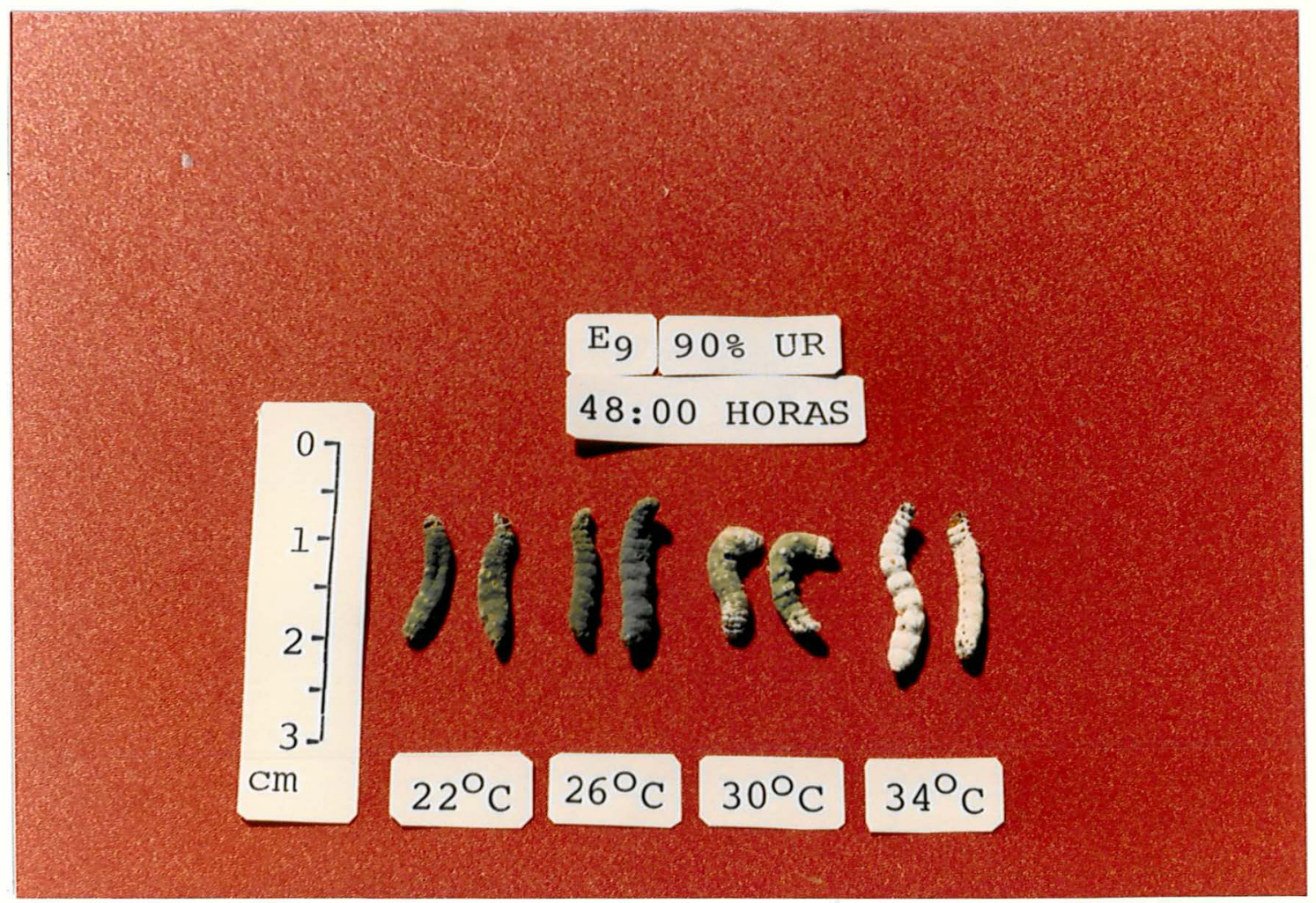

Figura 9. Desenvolvimento do isolado $E_{9}$ de $M$. anisopliae sobre cadáveres de lagartas de $D$. saccharalis incubados du rante 48 horas na umidade relativa do ar de $90 \%$, em diferentes temperaturas.

A produção de conídios dos isoladosde M. anisopliae sobre cadáveres de lagartas de $D$. saccharalis incubados durante 48 horas em diferentes temperaturas e na umidade relatí va do ar de 70\% encontram-se na Tabela 13 , onde se percebe uma certa tendência da produção de conîdios ser mais elevada nas 
temperaturas de $22 \pm 0,2{ }^{\circ} \mathrm{C}$ e $26 \pm 0,2^{\circ} \mathrm{C}$ e menor nas temperaturas mais altas como $30 \pm 0,2$ e principalmente $34 \pm 0,2^{\circ} \mathrm{C}$, nos três isolados, porém essa tendência não é tão nítida como a que ocorre na umidade de $90 \%$.

$\mathrm{Na}$ umidade relativa do ar de $50 \%$, a influencia das diferentes temperaturas sobre a produção de conídios já começa a ser prejudicada pela baixa umidade relativa, pois con forme pode ser observado na Tabela 14, não ocorreu grandes di ferenças, ao nível de $5 \%$ de significância, entre os tratamentos. Assim, a produção do isolado PL-43 na temperatura de $34 \pm 0,2^{\circ} \mathrm{C}$ foi superior às obtidas pelo mesmo isolado nas tempe raturas de $30 \pm 0,2$ e $26 \pm 0,2{ }^{\circ} \mathrm{C}$. A temperatura de $22 \pm 0,2^{\circ} \mathrm{C}$ foi a que proporcionou maior produção de conídios dos três isolados, tal vez devido ao fato dessa temperatura amenizar o efeito prejudicial da umidade relativa de $50 \%$, não permitindo uma desidra tação rāpida do micélio, a qual afetaria diretamente a conidiogênese. Dessa maneira, pode-se inferir que não é somente a temperatura ou somente a umidade relativa que vão influen ciar na conidiogênese, e sim a combinação desses dois fato res.

Através da Tabela 15, pode-se constatar que a umidade relativa do ar de $30 \%$ causou inibição da influēncia das diferentes temperaturas sobre a produção de conídios. Apenas na temperatura de $22 \pm 0,2^{\circ} \mathrm{C}$ o isolado PL-2 7 apresentou média mais elevada, a qual foi diferente ao nível de $5 \%$ de signi ficância,das médias dos tratamentos com o número de ordem 8 


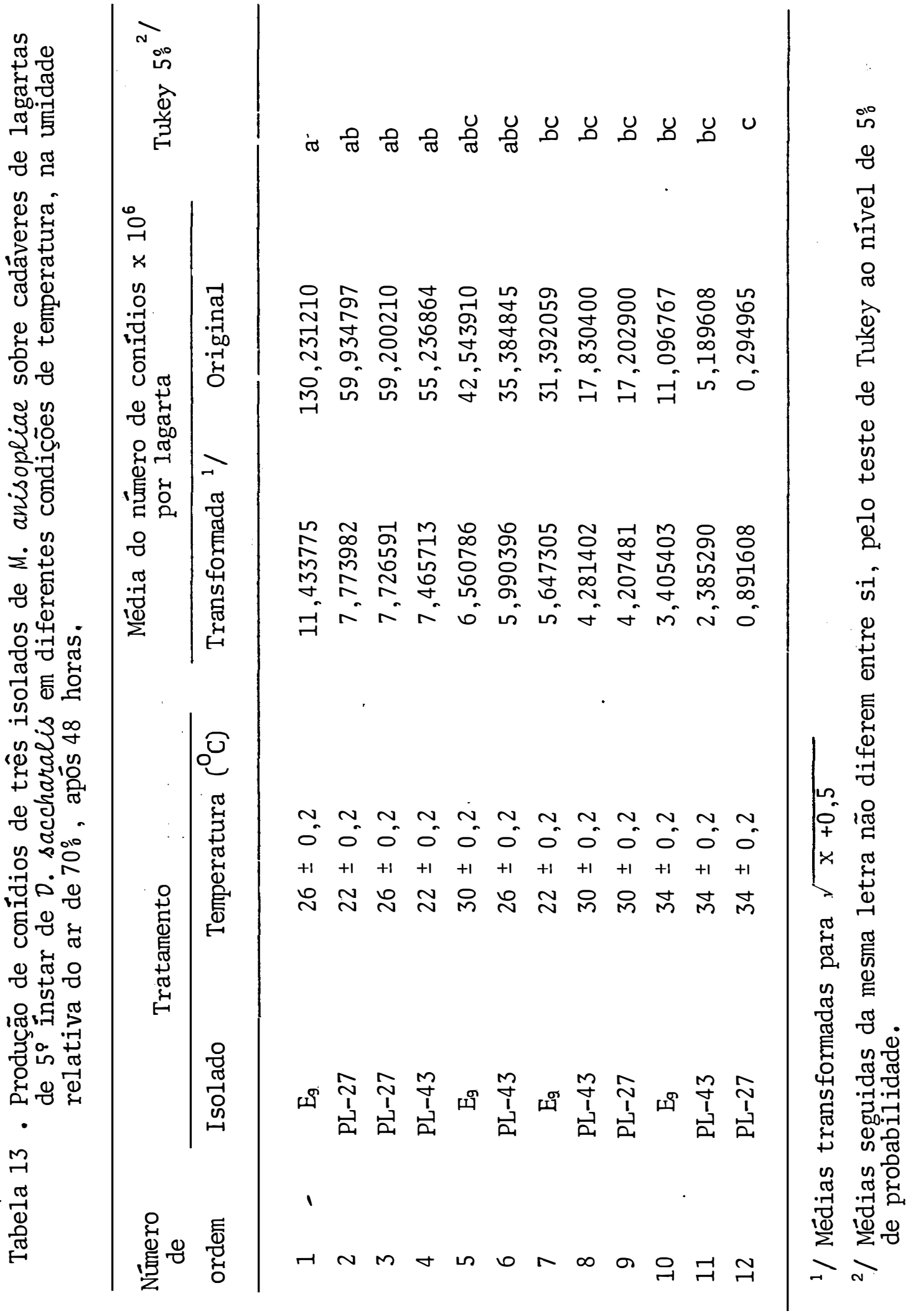




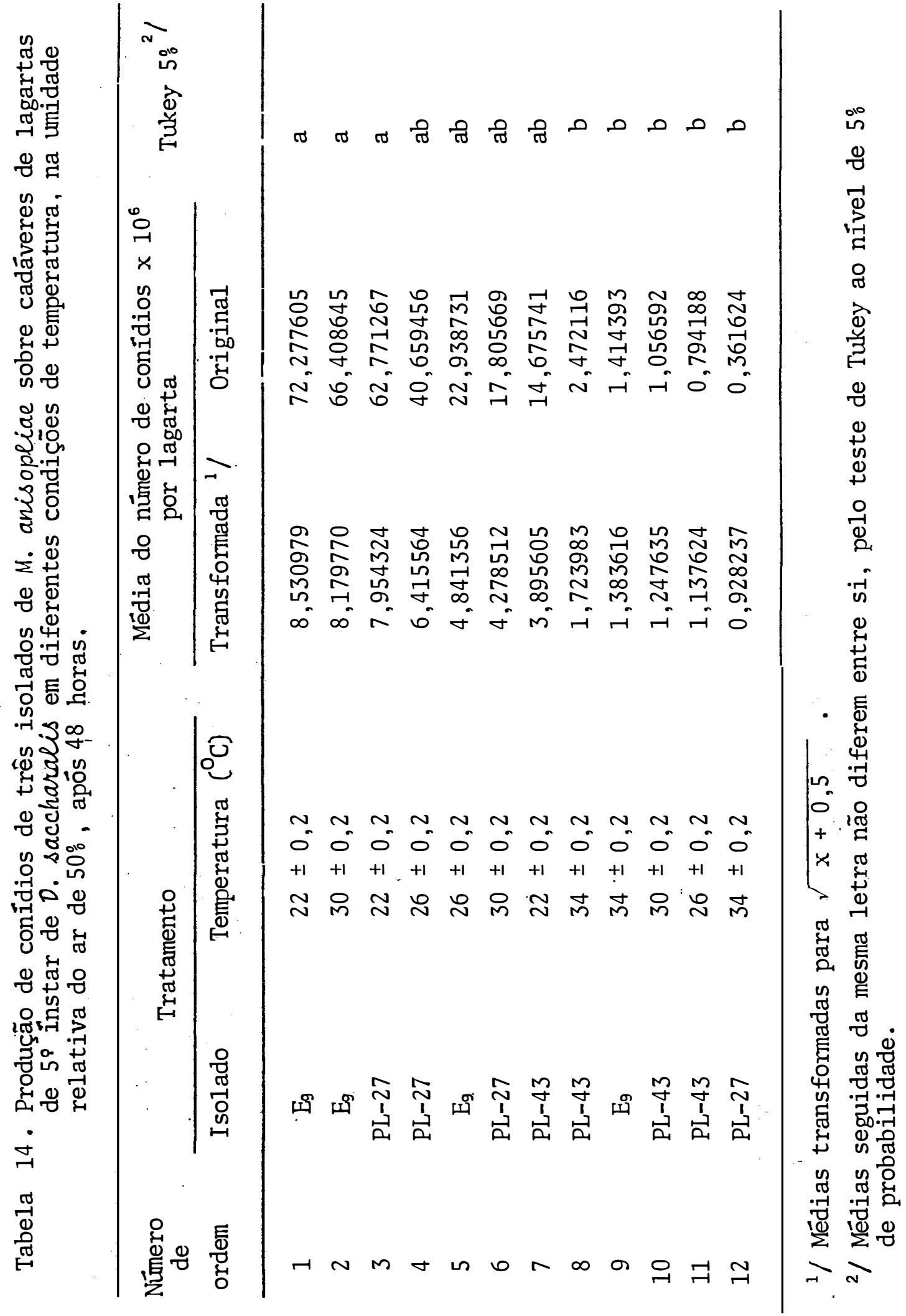


.81 .

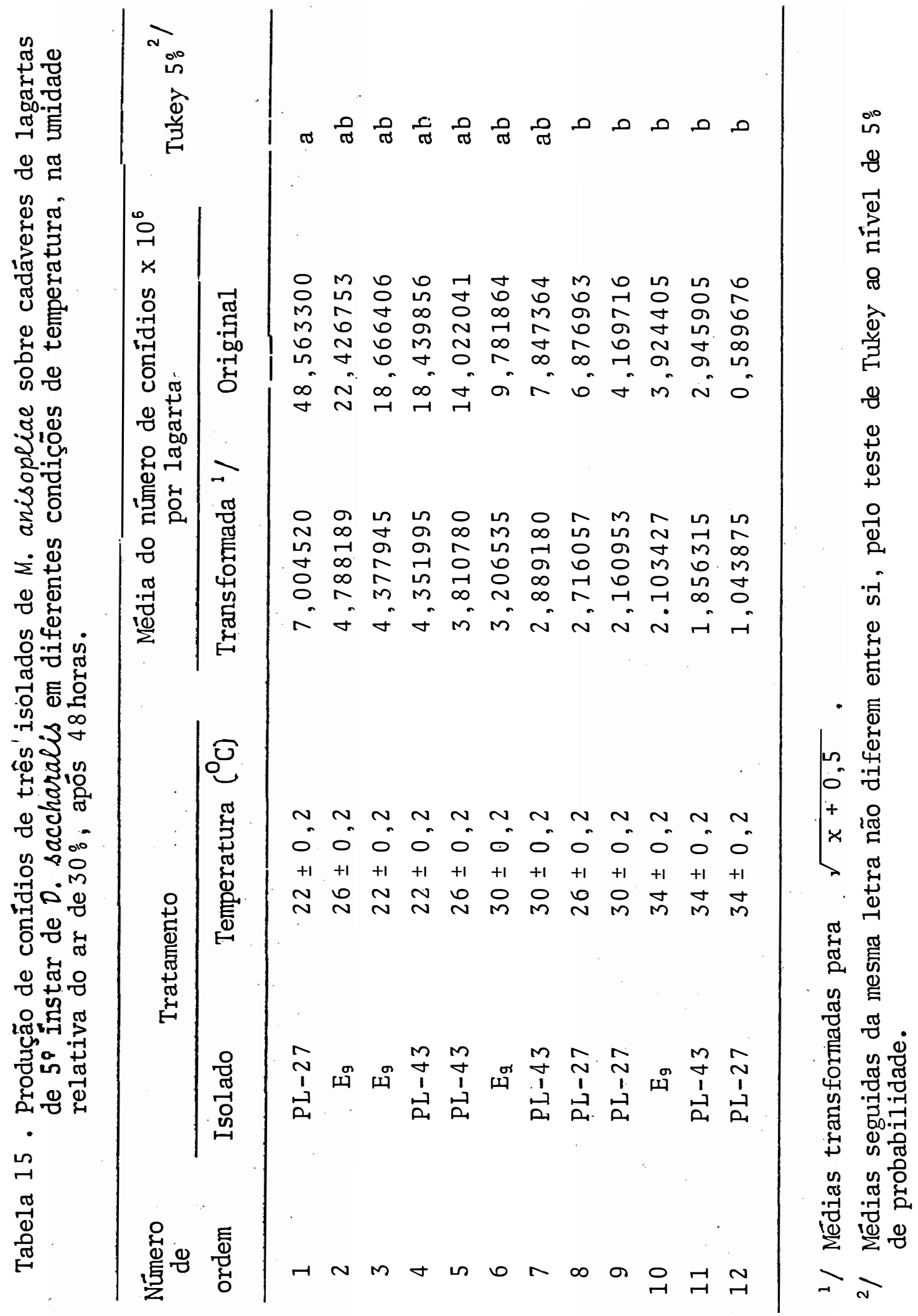


a 12. A umidade relativa de $30 \%$ pode provocar uma perda de água do micélio, ressecando-o e fazendo com que o número de conídios seja reduzido. Percebe-se que a temperatura de $22 \pm 0,2^{\circ} \mathrm{C}$ na umidade relativa de $30^{\circ}$ foi a mais favorável para a conidiogênese e que a temperatura de $34 \pm 0,2^{\circ} \mathrm{C}$ foi a mais pre judicial, pois se associou alta temperatura com baixa umidade relativa. Esta associação proporcionou a condição mais des favorávei ao patógeno na presente pesquisa.

\subsection{Determinação da Viabilidade dos conidios DEM.anisopliae PRODUZIDOS SOBRE CADÁVERES DE LAGARTAS DE D.saccharalis SUBMETIDOS A DIFERENTES CONDIÇÕES DE TEMPERATURA E UMIDADE RELATIVA DO AR}

Os dados referentes à viabilidade dos conídios dos isolados $E_{9}, \mathrm{PL}-27$ e PL-43 de M. anisoplial produzidos so bre cadáveres de lagartas de $D$. saccharalis submetidos a diferentes períodos de tempo e a diferentes temperaturas na umi dade relativa do ar constante de $90 \%$, encontram-se na Tabela 16 .

Pode-se verificar que após 96 horas (Tabela 16) houve um pequeno decréscimo na viabilidade dos conídios subme tidos às temperaturas de $22 \pm 0,2,30 \pm 0,2$ e $34 \pm 0,2{ }^{\circ} \mathrm{C}, \quad$ porém mantiveram-se próximas de $100 \%$. Isto pode ser atribuído à umi dade relativa de $90 \%$, que não permitiu que houvesse um resse- 


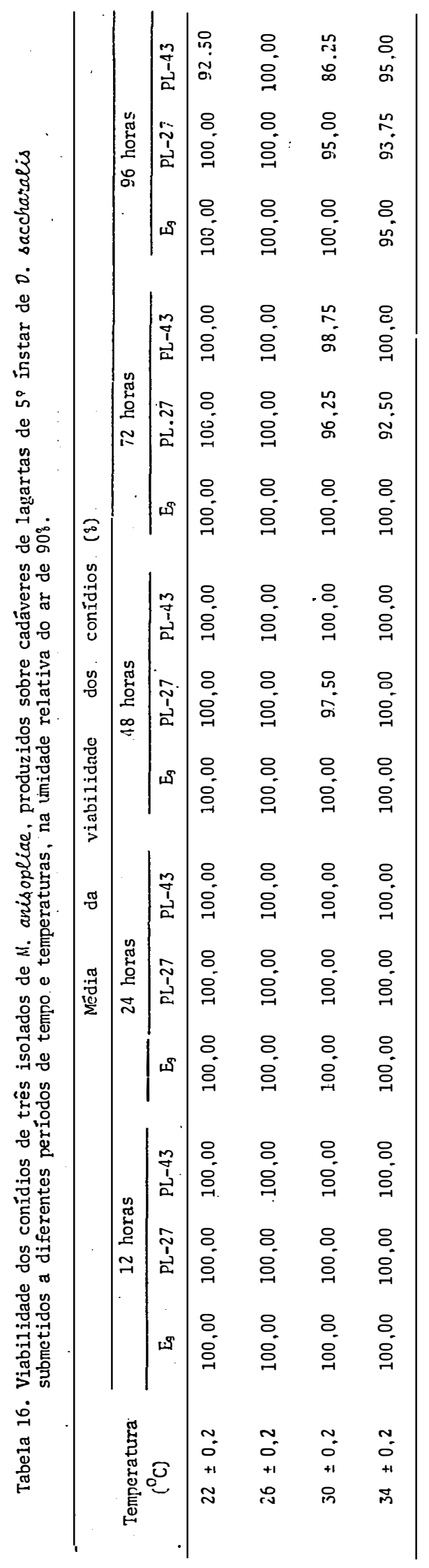


camento dos conídios, o que poderia prejudicar a germinação, até mesmo na temperatura de $34 \pm 0,2^{\circ} \mathrm{C}$. Estes resultados coincidem com os obtidos por MacLeod et alii, citados por BELL (1974), onde mencionam que os conîdios possuem uma delicada mem brana externa podendo perder ou ganhar água rapidamente, de acordo com a umidade do ar, sendo que em atmosferas insaturadas perdem facilmente a viabilidade. Pôde-se constatar que a umidade relativa de $90 \%$ não permitiu que a viabilidade dos co nídios dos três isolados sofresse uma queda mais brusca nas diferentes temperaturas com o passar do tempo, o que não possibilitou a visualização nítida do tempo de incubação dos cadáveres de lagartas, mais adequado para se determinar a influên cia das temperaturas testadas, sobre a viabilidade dos conídios produzidos nos diferentes períodos de tempo testados.

Ao se verificar a influência das diferentes umidades relativas sobre a viabilidade dos conídios, em diferentes períodos de tempo, na temperatura constante de $26 \pm 0,2{ }^{\circ} \mathrm{C}$, pôde-se determinar conforme consta na Tabela 17, o tempo de incubação suficiente para que esses efeitos fossem bastante per ceptíveis. Observa-se por essa tabela, que após 48 horas de incubação a viabilidade continua elevada nos três isolados, não sendo possível diferenciar a(s) temperatura(s) mais adequada(s) para a manutenção da viabilidade das temperaturas des favorāveis. Após 72 horas jā se conseguiu visualizar esses efeitos, mas quando se testou a viabilidade desses conídiospro duzidos e incubados nas diferentes umidades durante 96 horas, 


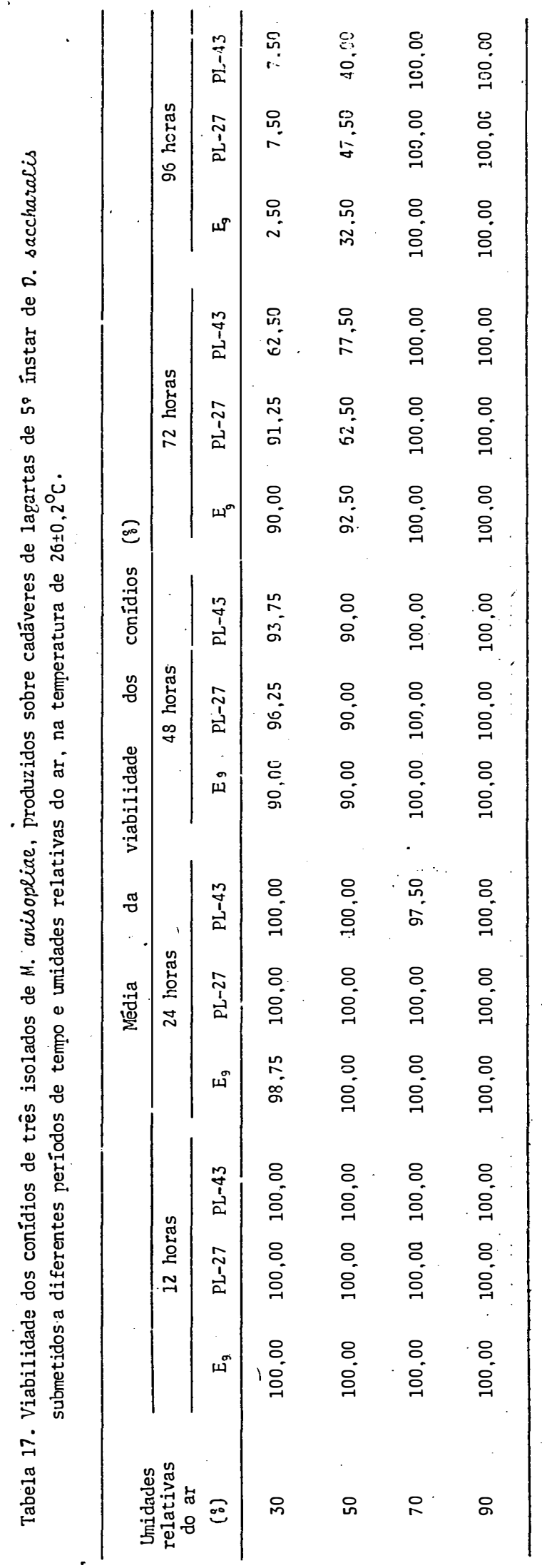


verificou-se que este é o tempo ideal para essa diferenciação. Assim, constatou-se que: as umidades relativas de 90 e $70 \%$, quando associadas à temperatura de $26 \pm 0,2^{\circ} \mathrm{C}$, são altamente fa voráveis para a manutenção da viabilidade; que na umidade de $50 \%$ os conídios dos três isolados sofrem uma perda considerável dessa viabilidade e que a $30 \%$ os conídios quase perdem to talmente sua viabilidade.

Pode-se visualizar melhor esses efeitos através da representação gráfica para o isolado $E_{9}$, na Figura 10.

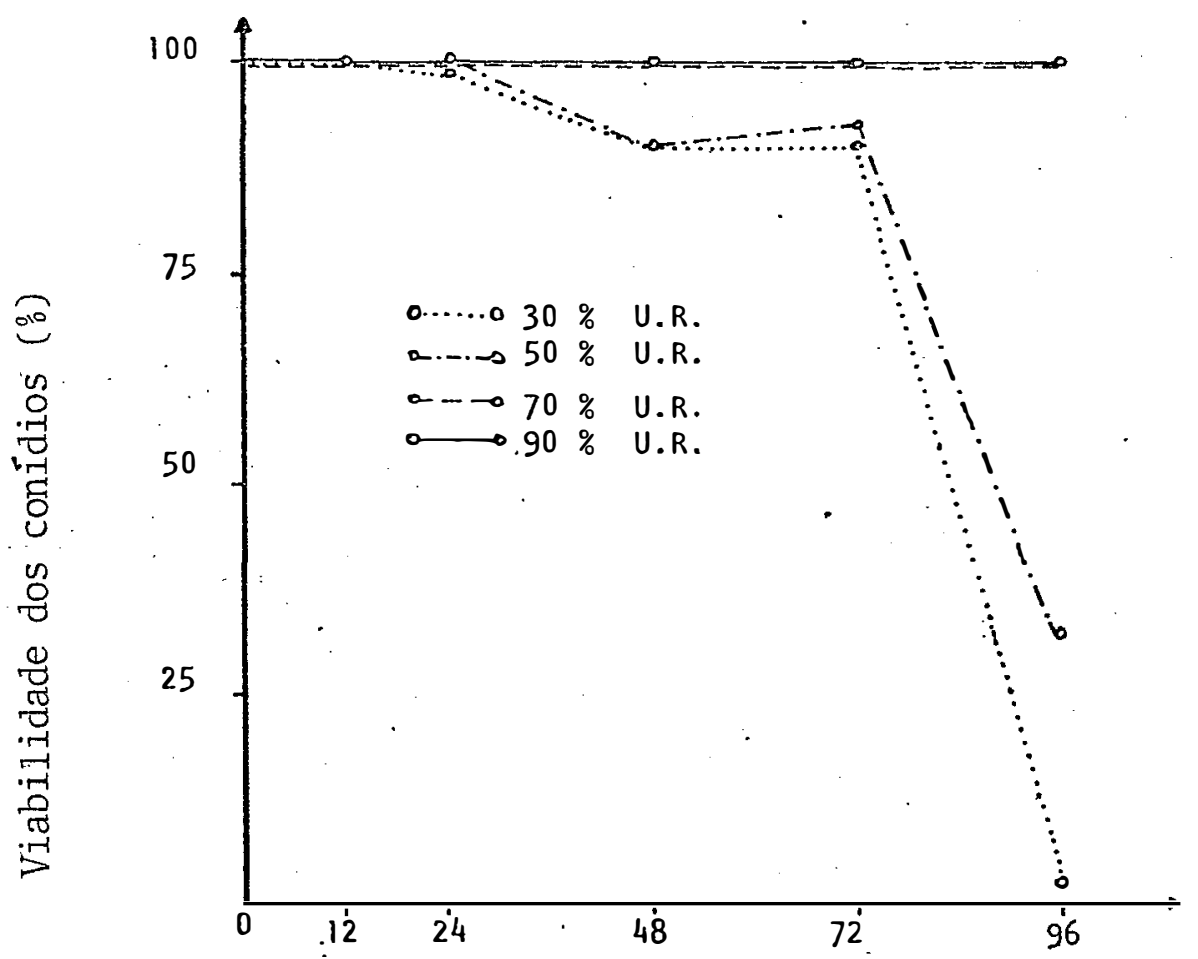

Horas no dessecador

Figura 10. Viabilidade dos conídios do isolado $E_{9}$ de M.anisopliae produzidos sobre cadáveres de lagartas de $5^{\circ}$ ínstar de D. saccharalis incubados em diferentes umidades relati vas do ar, durante diferentes períodos de tempo, na temperatura de $26 \pm 0,2^{\circ} \mathrm{C}$. 
A comparação das médias de viabilidade dos conídios dos isolados $\mathrm{E}_{9}, \mathrm{PL}-27$ e PL-43, produzidos sobre cadá veres de lagartas de $D$. saccharalis incubados durante 96 horas, em diferentes temperaturas e umidades relativas do ar, realizada pelo teste de Tukey ao nível de 5\% de probabilidade, encontra-se na Tabela 18.

Os resultados evidenciam que tanto a umidade relativa do ar como a temperatura afetam a viabilidade dos co nídios dos três isolados, sendo que o efeito da interação de $\underline{s}$ ses dois fatores é que vai permitir ou não que os conídios se mantenham viáveis. Ao se observar cada temperatura individua 1 mente, verifica-se que a medida que a umidade relativa diminui, a viabilidade dos conídios tende a decrescer. Observa se também que em umidades relativas iguais ou inferiores a $70 \%$, os conídios tendem a se tornarem inviáveis a medida que a tem peratura aumenta. Os tratamentos que mantiveram a viabilidade dos conídios dos três isolados, após 96 horas, iguais ou próximas de $100 \%$ foram os que apresentaram as seguintes comb $\underline{i}$ nações de temperatura e umidade relativa: $22 \pm 0,2{ }^{\circ} \mathrm{C}$ com umi dades de 90,70 e $50 \% ; 26 \pm 0,2{ }^{\circ} \mathrm{C}$ com umidades de 90 e $70 \% ; 30 \pm 0,2$ ${ }^{\circ} \mathrm{C}$ e $34 \pm 0,2^{\circ} \mathrm{C}$ com $90 \%$ de umidade relativa. As combinações de temp̣eratu ras iguais ou superiores a $30 \pm 0,2{ }^{\circ} \mathrm{C}$ com umidades relativas iguais ou inferiores a $50 \%$ foram altamente desfavoráveis à manutenção da viabilidade dos conídios. Resultados semelhantes foramobtidos por WALSTAD et alii (1970), SANTOS (1978), DAOUST e ROBERTS (1983), ALVES(1984) e ALVES e NOGUEIRA(1984). 


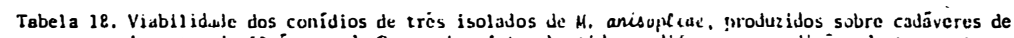
lapartas de se instar de $\mathfrak{D}$. saccharalas submitidos a diferentes condiçóes de temperatura e conldade telativa do ar, ajós 90 horas.

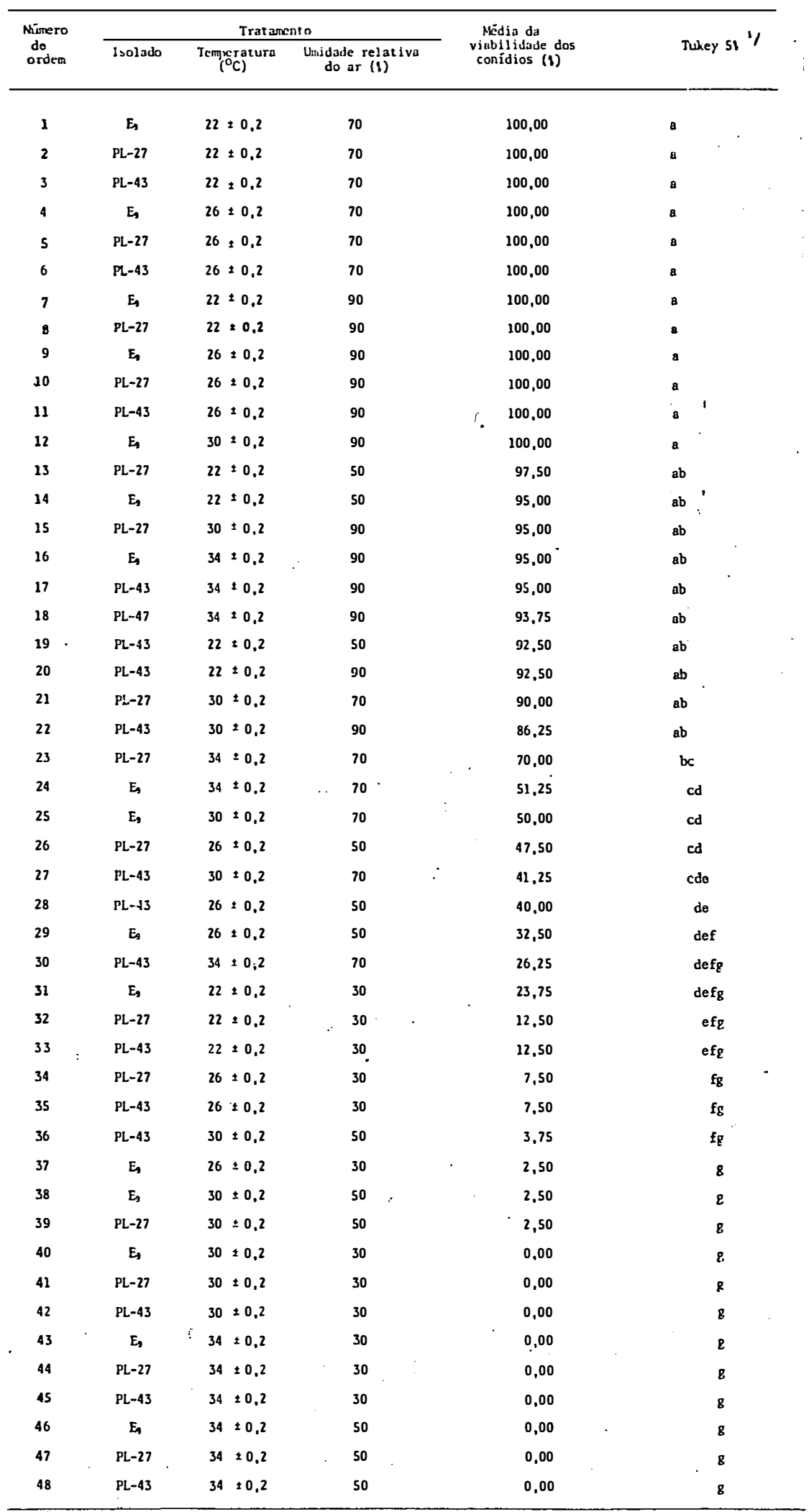

1) MEsias seguidas da mesma letra não diferen entre si, pelo teste de Tykey ao nível de si de probabilidade.

Teste F entre tratamentos: $F=435,62 \cdot \bullet$

C.v.(1) $=7,76419$ 
.89 .

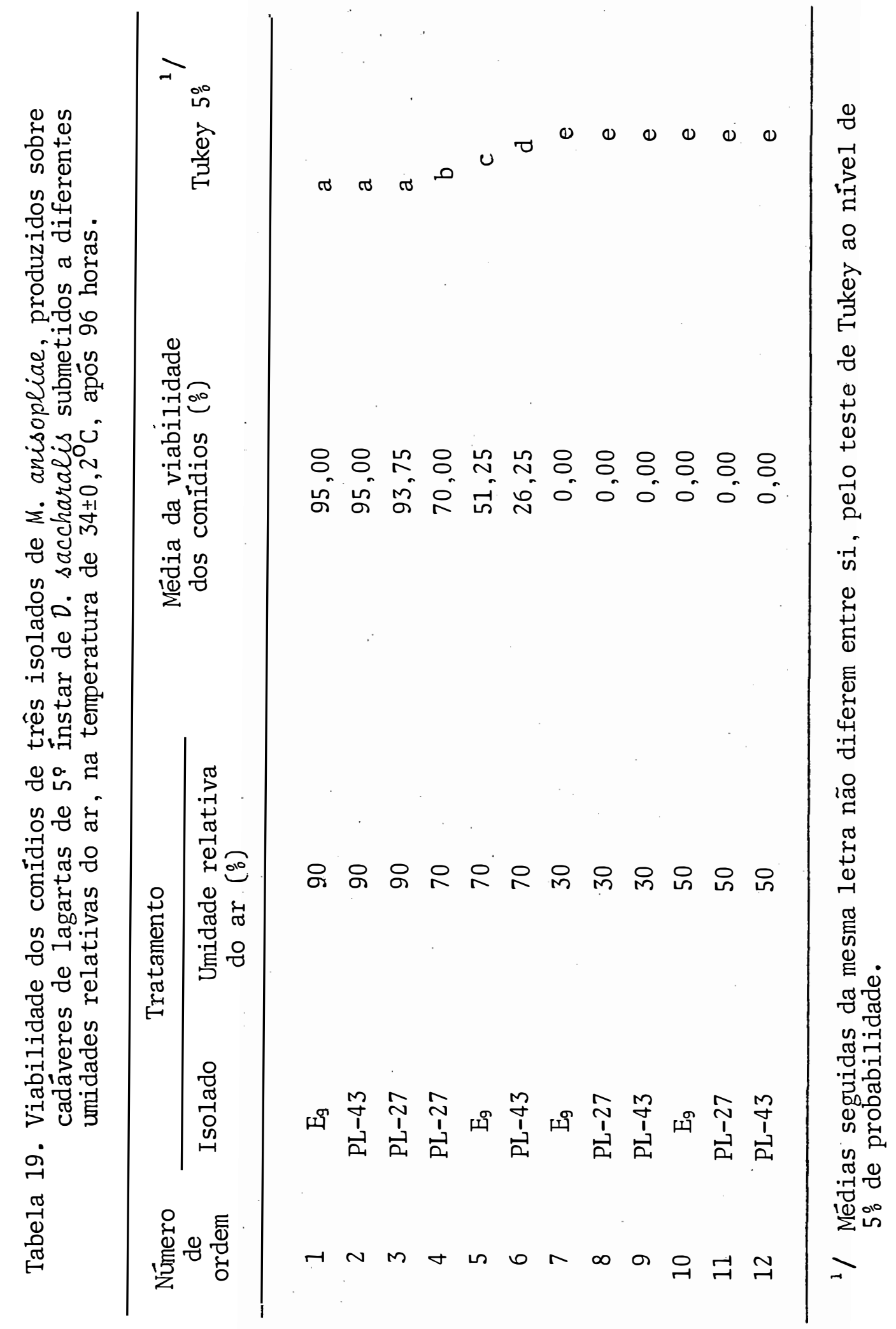


Através da Tabela 19. pode-se observar o efeito das diferentes umidades relativas sobre a viabilidade dos conídios dos três isolados, na temperatura constante de $34 \pm 0,2^{\circ} \mathrm{C}$, onde se verifica que somente na umidade relativa de $90 \%$ a viabilidade manteve-se elevada (próxima de $100 \%$ ). Os conídios pro duzidos e expostos à umidade relativa de $70 \%$ apresentaram uma redução considerável em suas viabilidades. Isso se deve, pro vavelmente, à grande perda de umidade, através da delicada mem brana externa dos conídios, conforme trabalho de MacLeod et alii, citados por BELL (1974). Nas umidades relativas de 50 e $30 \%$ a viabilidade foi zero, demonstrando o efeito prejudicial da temperatura de $34 \pm 0,2{ }^{\circ} \mathrm{C}$ quando associada a baixas umidades. Dessa maneira, a aplicação em campo, de qualquer um desses isolados pode ser realizada em dias com temperaturas elevadas como $34 \pm 0,2^{\circ} \mathrm{C}$ desde que a umidade relativa se ja igual ou superior a $90 \%$, porém nos dias subsequentes a tem peratura deverá diminuir para que possa ocorrer uma alta produção de conídios sobre os insetos mortos.

Pode-se verificar na Tabela 20 , que na tempera tura de $30 \pm 0,2^{\circ} \mathrm{C}$, apenas a umidade relativa de $90 \%$ permitiu que a viabilidade dos conídios dos três isolados se mantivesse elevada (próxima de $10(1 \%$ ), sendo que a $70 \%$ de umidade relatí va somente o isolado PL-27 apresentou os mesmos índices e os outros isolados tiveram a viabilidade de seus conídios bastante reduzida. Nas umidades relativas de 50 e $30 \%$ os conídios perderam, apōs 96 horas, praticamente toda a sua viabilidade. Is 
.91.

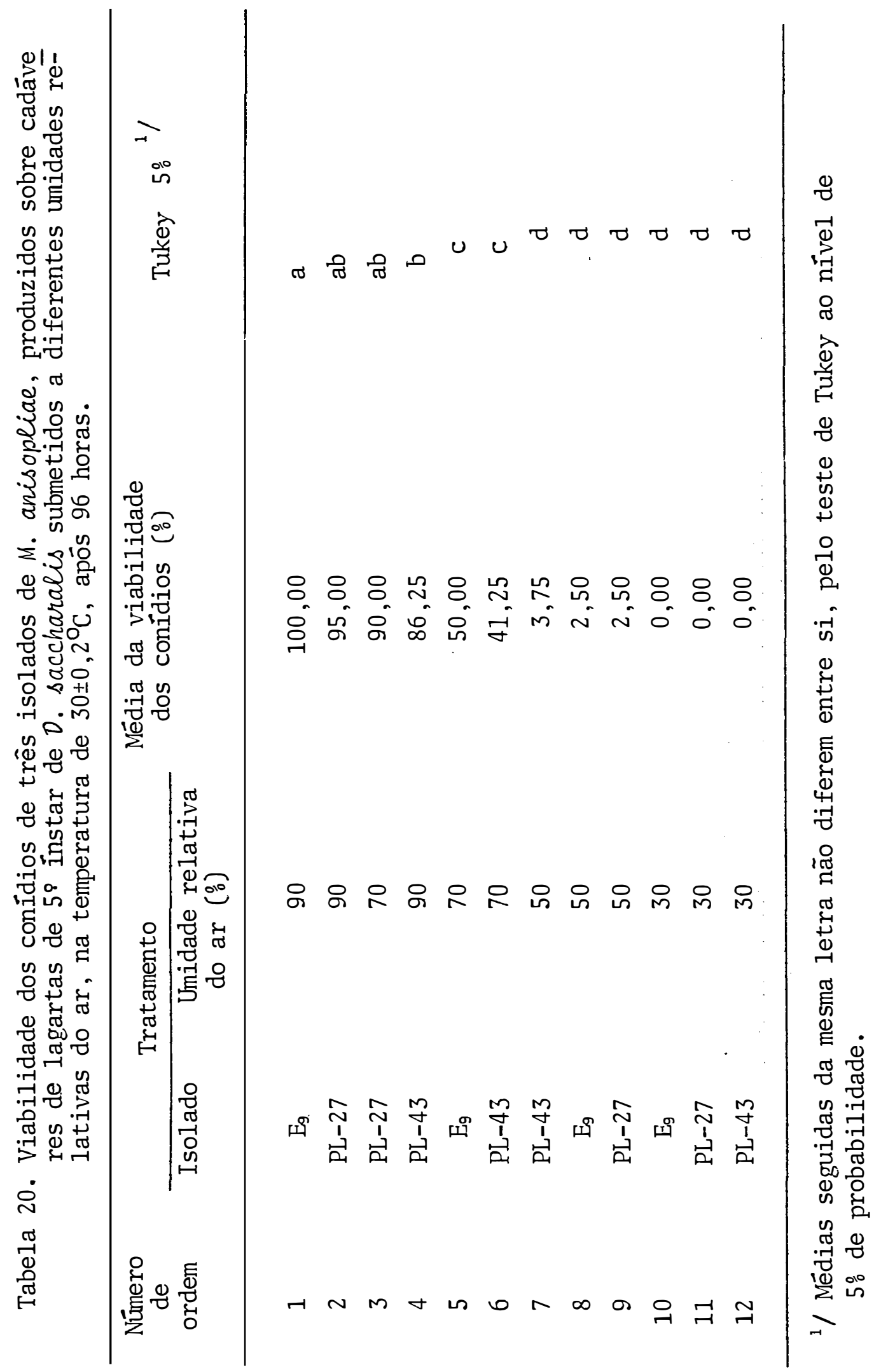




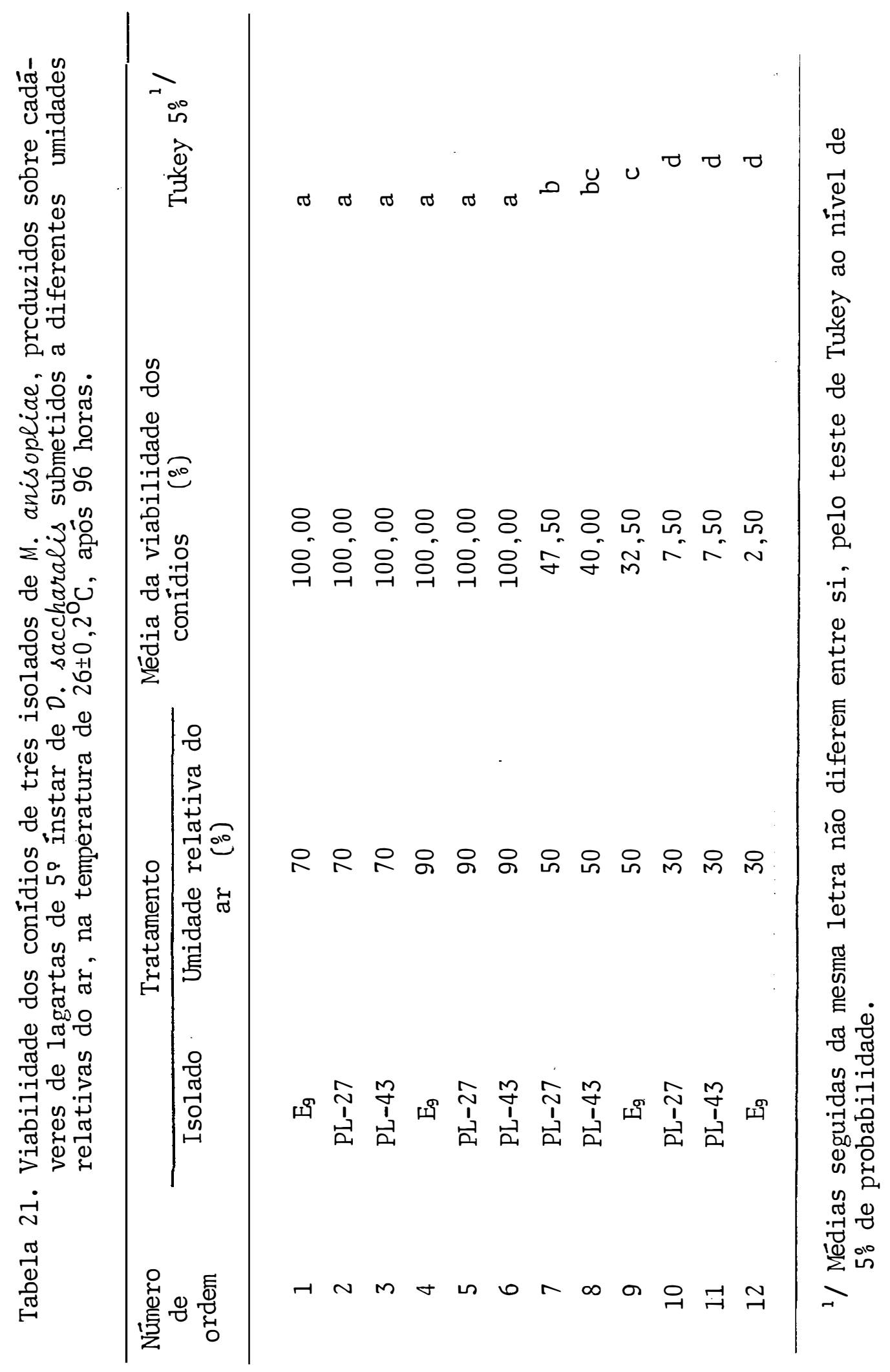


so ocorreu, provavelmente em função de uma desidratação, qual prejudicou a viabilidade dos mesmos. Também observa-se que na temperatura de $30 \pm 0,2^{\circ} \mathrm{C}$, a medida que a umidade relativa decresce, a viabilidade dos conídios também diminui.

Constata-se através da Tabela 21 , que na tempe ratura de $26 \pm 0,2^{\circ} \mathrm{C}$ os efeitos das diferentes umidades relativas sobre a viabilidade dos conídios são bastante pronunciados, permitindo dizer que após 96 horas, nessas condições, as umidades de 90 e $70 \%$ são altamente favoráveis à germinação dos conídios dos três isolados testados. Na umidade relativa de $50 \%$ os conídios já perdem boa parte de sua viabilidade e a $30 \%$ os conídios tendem a perder totalmente slia capacidade de germinar. Resultados semelhantes foram obtidos por DAOUST e ROBERTS (1983), os quais ao estudarem o efeito do armazenamen to prolongado de conídios do isolado $E_{9}$ de $M$. anisopliae em diferentes temperaturas e umidades relativas sobre a viabilidade e virulência desses conídios, puderam constatar que a umidade menos favorável, na faixa de 19 a $26^{\circ} \mathrm{C}$, foi de $33 \%$.

Os valores referentes às viabilidades dos conídios dos isolados $E_{9}$, PL-27 e PL-43 produzidos sobre cadáve res de lagartas de $D$. saccharalis incubados durante 96 horas em diferentes umidades relativas com a temperatura constante de $22 \pm 0,2^{\circ} \mathrm{C}$, encontram-se na Tabela 22 . Observa-se que não houve diferença, ao nível de $5 \%$ de significância, entre as viabilidades dos conídios dos três isolados nas umidades rela tivas de 90,70 e $50 \%$, sendo que todos os valores ficaram pró- 
.94.

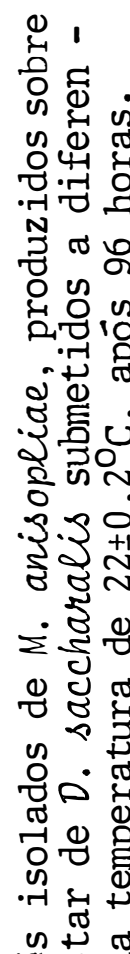

州岕

tr.

ข) 夰

थ

검

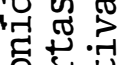

Оᄋ

ข

유다

ه ఖ

ช్రు थ

ত ర్త

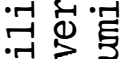

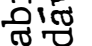

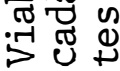

N

N

它

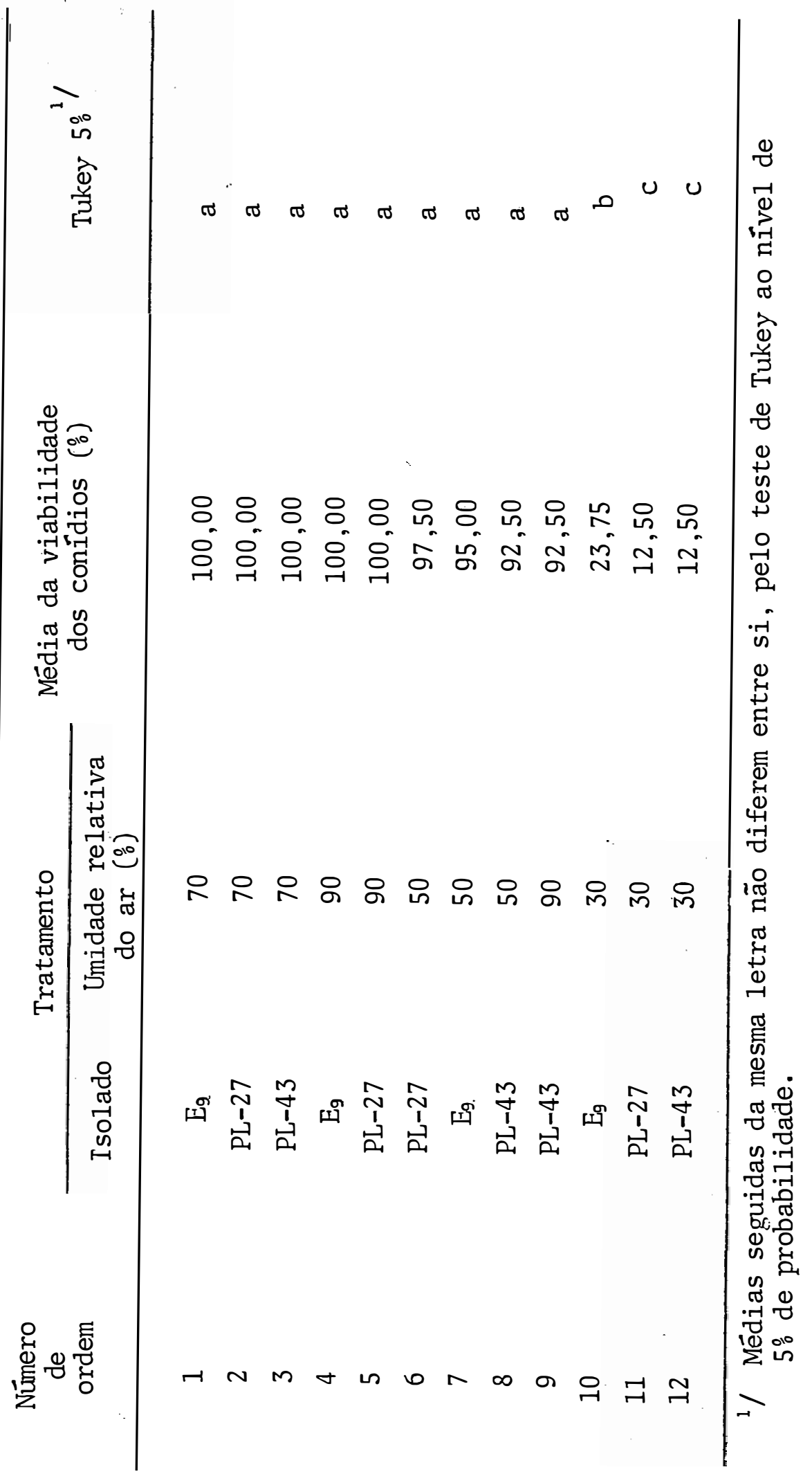




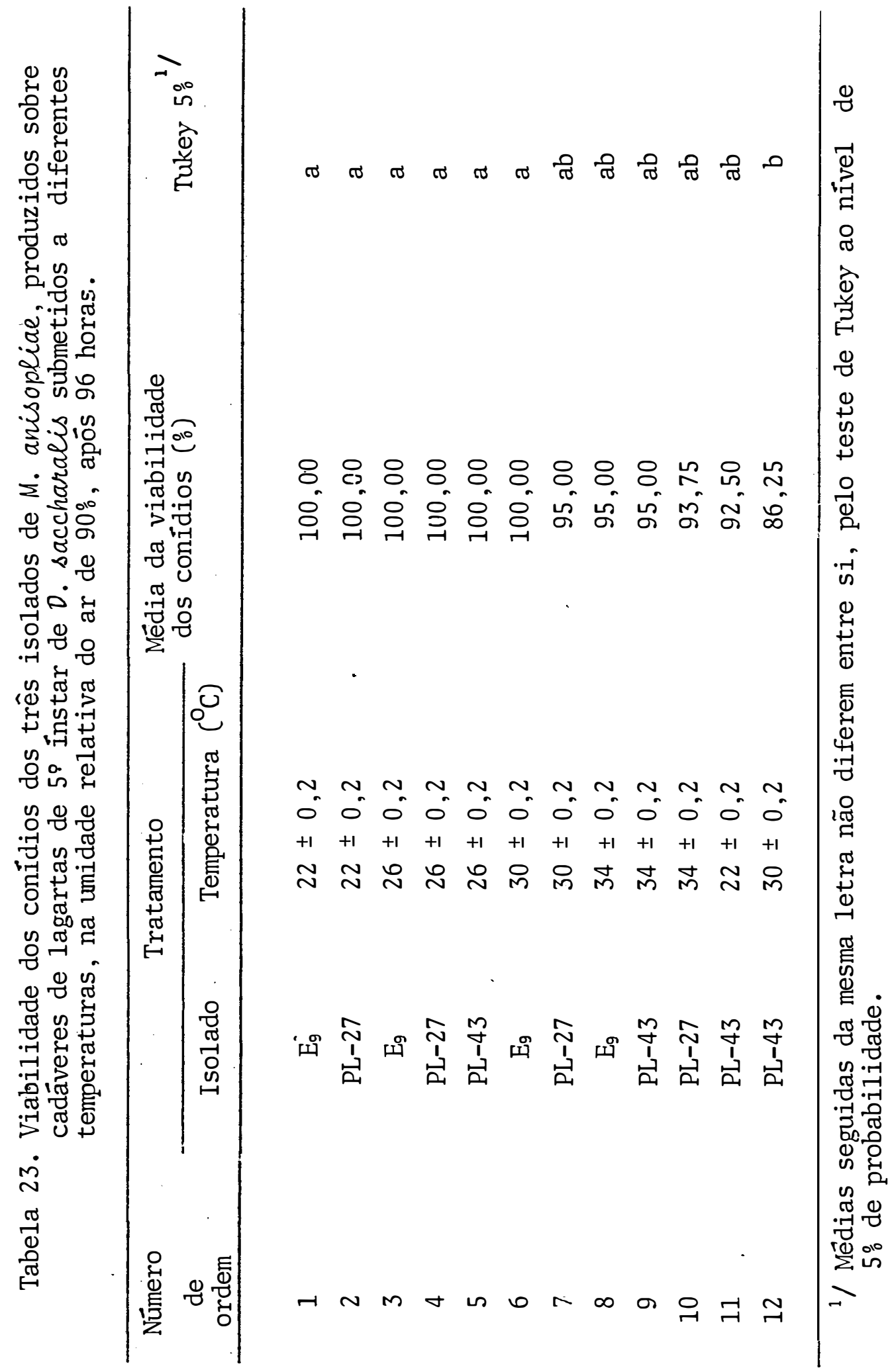


ximos de $100 \%$. Somente a umidade relativa de $30 \%$ foi prejudicial à manutenção da viabilidade dos conídios na temperatú ra de $22 \pm 0,2^{\circ} \mathrm{C}$, provavelmente devido a esta umidade ser muito baixa fazendo com que os conídios perdessem água, afetando dessa maneira a capacidade de germinar.

Através da Tabela 23 , pode-se constatar que em umidades relativas como $90 \%$, a viabilidade dos conídios dos $\underline{i}$ solados $E_{9}$, PL-27 e PL-43 permaneceu elevada após o tempo de 96 horas, independentemente da temperatura, dentro da faixa testada de $22 \pm 0,2{ }^{\circ} \mathrm{C}$ a $34 \pm 0,2{ }^{\circ} \mathrm{C}$. E provável: que a alta umidade não favoreça a perda de água dos conídios para o ambiente externo, o que evitaria a perda da viabilidade dos mesmos. Os dados relativos à viabilidade dos conídios produzidos sobre cadáveres de lagartas de $D$. saccharalis incu bados durante 96 horas em diferentes temperaturas com a umida de relativa de $70 \%$, encontram-se na Tabela 24 . Observa-se que a viabilidade dos conídios dos três isolados foi de $100 \%$ nas temperaturas de $22 \pm 0,2{ }^{\circ} \mathrm{C}$ e $26 \pm 0,2^{\circ} \mathrm{C}$ e que somente os conidios do isolado $\mathrm{PL}-27$ na temperatura de $30 \pm 0,2{ }^{\circ} \mathrm{C}$ mantiveram-se tão viáveis quanto os citados anteriormente.

Observa-se pela Tabela 25 , que na umidade rela tiva de $50 \%$, apenas a temperatura de $22 \pm 0,2^{\circ} \mathrm{C}$ permitiu que os conídios dos três isolados se mantivessem altamente viáveis (viabilidade próxima de $100 \%$ ), provavelmente em função desta temperatura ter compensado o efeito desfavorável da umidade re lativa de $50 \%$, não deixando que os conídios sofressem uma per 
.97.

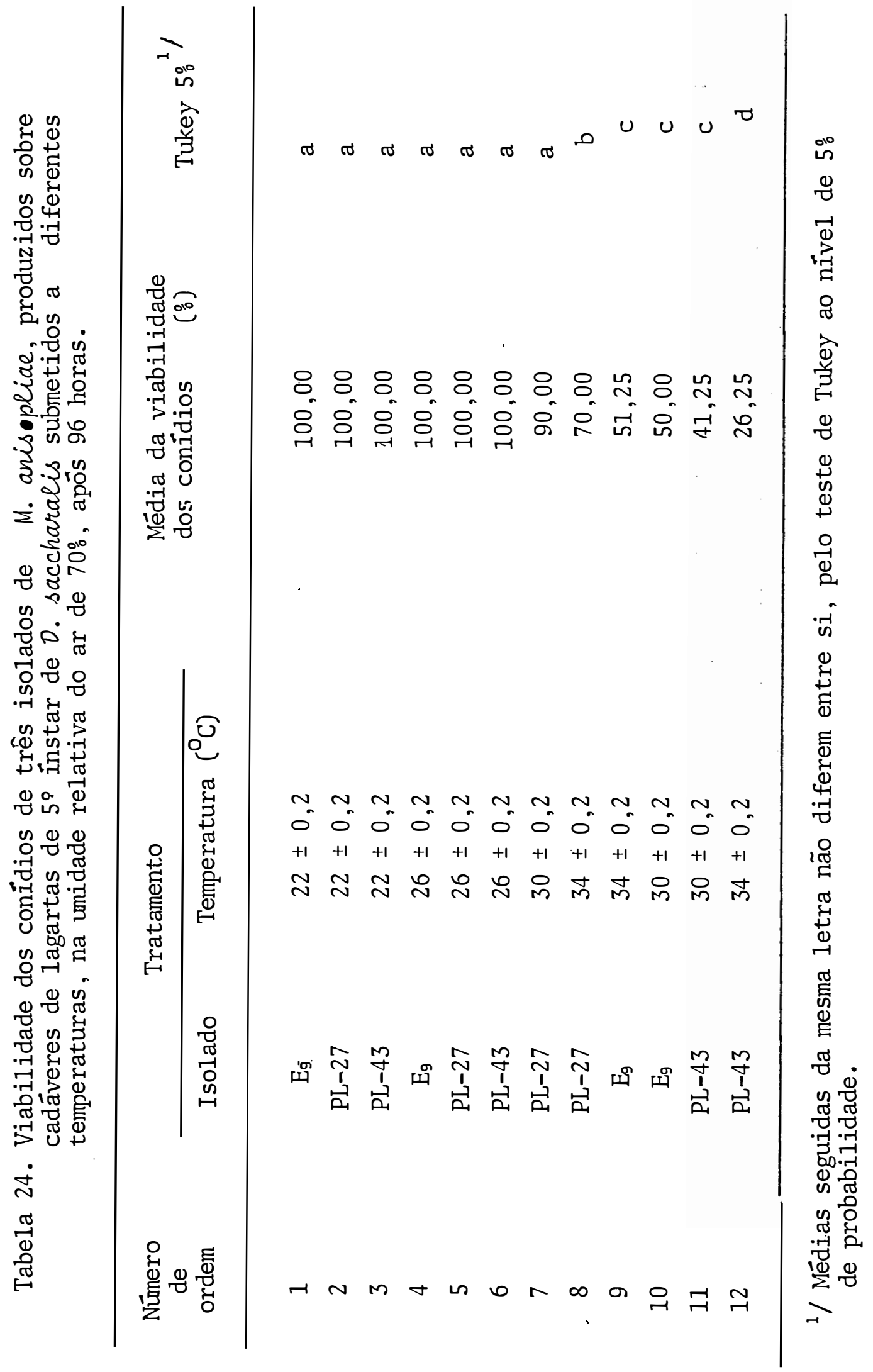




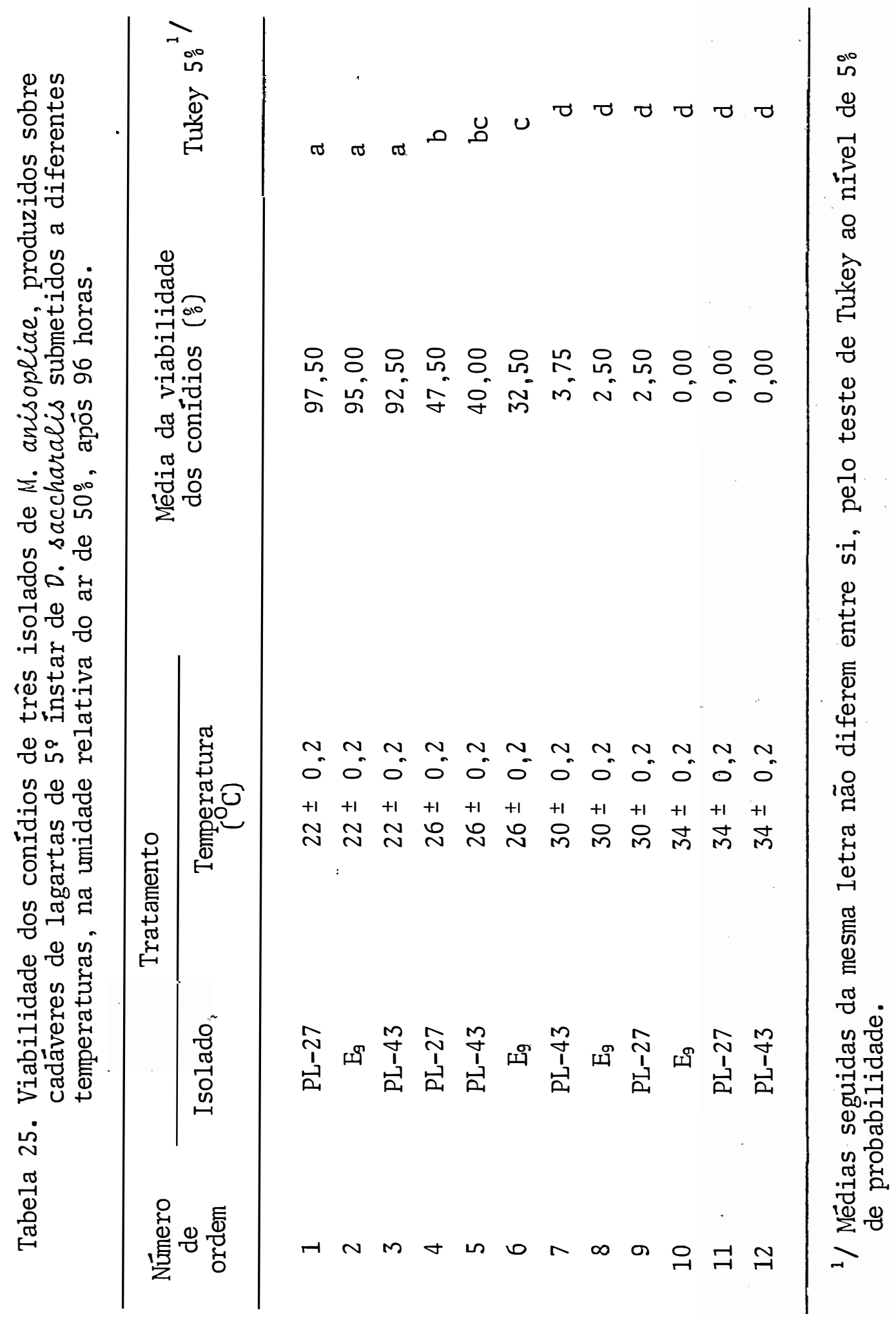




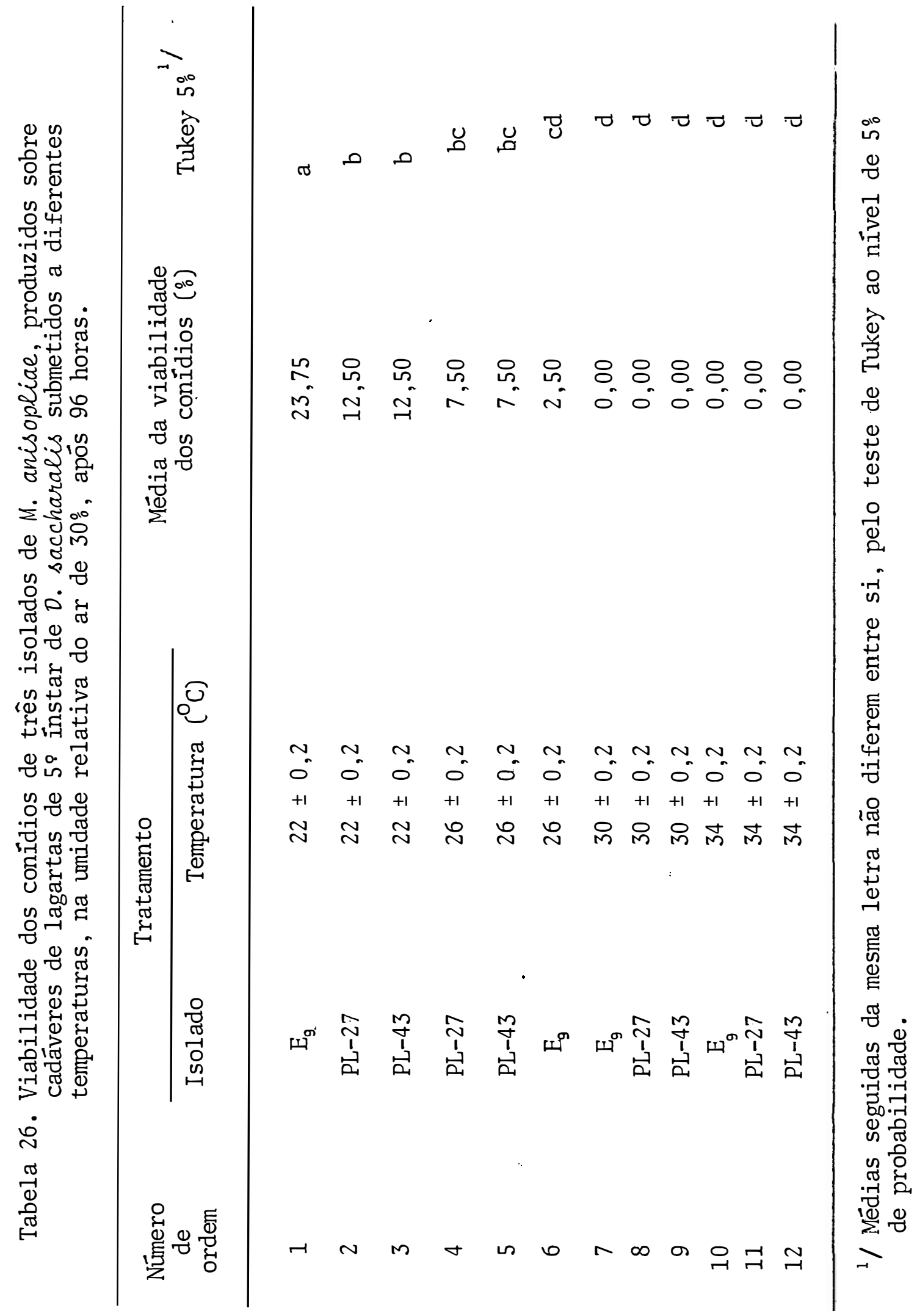


da de água excessiva para o ambiente externo, o que não aconteceu nas demais demais temperaturas testadas. Nesta umidade relativa, a medida que a temperatura aumenta, a viabilidade dos conídios decresce, chegando a ser igual a zero na tempera tura de $34 \pm 0,2^{\circ} \mathrm{C}$.

Pode-se constatar através da Tabela 26 , que a viabilidade dos conídios dos isolados $E_{9}$, PL-27 e PL-43 produzidos sobre cadáveres de lagartas de $D$. saccharalis incubados durante 96 horas a $30 \%$ de umidade relativa, foi bastante afetada em todas as temperaturas, pois a porcentagem máxima de viabilidade encontrada foi de $23,75 \%$ para os conídios do iso lado $E_{9}$ na temperatura de $22 \pm 0,2^{\circ} \mathrm{C}$. Assim a umidade relativa de $30 \%$ foi a responsável por esse resultado, provavelmente por ter provocado uma perda de água do interior dos conídios para o ambiente externo ressecando os conídios e fazendo com que os mesmos perdessem sua capacidade de germinação.

\subsection{U'tilizaçĀo DE $M$. anisopliae com base EM CLimogramas}

Após a aplicação de M. anisopliae a nível de campo, alguns fatores não controláveis podem afetar a viabilí dade e a posterior germinação dos conídios, a reprodução e a disseminação do fungo no ambiente, não permitindo a ocorrência de epizootias. Assim, hā necessidade de estudos epizootiológ cos visando a utilização mais racional dos patógenos em pro- 
gramas de manejo integrado de pragas (TANADA, 1963; FERRON, 1978; KISH e ALLEN, 1978; FERRON, 1981; VENTURA, 1981; WEISER, $1982)$.

Baseando-se nos resultados de produção de coní dios (Tabela 7) e nos resultados de viabilidade dos conídios (Tabela 18) dos isolados $E_{9}$, PL-27 e PL-43, pôde-se determinar quais as condições de temperatura e umidade relativa do ar que atendem às exigências térmicas e hídricas dos três iso lados de M. anisopliae para se obter altas produções de conídios viáveis (Tabela 27). Não é vantajoso ao controle microbiano conseguir alta produção de conídios se estes perdem rapidamente a sua viabilidade. Do mesmo modo, não adianta se obter conídios altamente viáveis em uma quantidade insuficien te para a formação de focos primários da doença.

o número de conídios produzidos sobre cadáveres de lagartas de $5^{\circ}$ instar de $D$. saccharalis considerado como mínimo, foi de $14,67 \times 10^{6}$ conídios por lagarta, conforme foi discutido no item 4.2. (Tabela 7). E a porcentagem de viabili dade dos conídios produzidos sobre cadáveres de 5 ? instar de D. saccharalis considerada como mínima, foi de $86,25 \%$, confor me foi discutido no item 4.3. (Tabela 18).

Observa-se na Tabela 27 , que ambientes que pos suem temperaturas de: $22 \pm 0,2{ }^{\circ} \mathrm{C} ; 26 \pm 0,2{ }^{\circ} \mathrm{C}$ e $30 \pm 0,2{ }^{\circ} \mathrm{C}$, associadas respectivamente a umidades relativas iguais ou superiores a 50,70 e $90 \%$, são favoráveis à obtenção de uma alta produção de conídios de qualquer um dos isolados testados, que permanece 
$\approx \approx$

森怘

క్․․

है.

䒕

茞

10 వై

.

究

实o

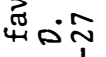

幽它罟

음 要

용

荧的鸪

엄 윰

뜡

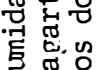

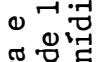

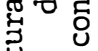

必包

衰苋

ه

ข

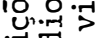

㞯武茟

ชु ช्ष

N

స్ల

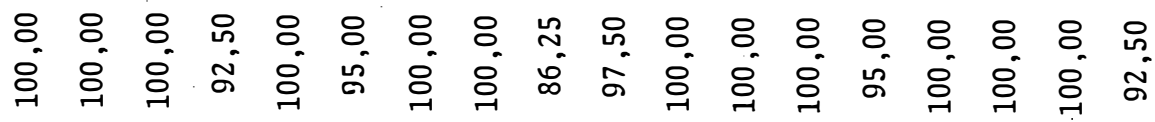

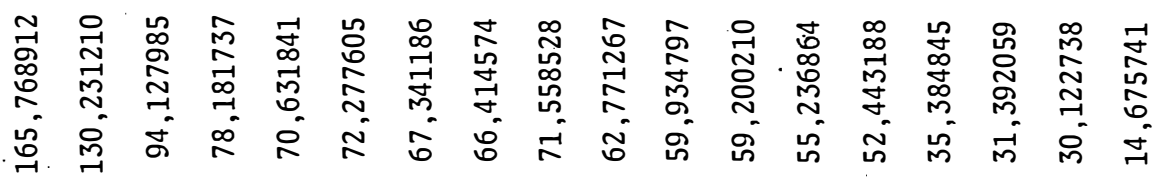

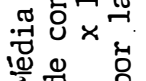

ช.

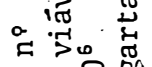

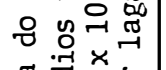

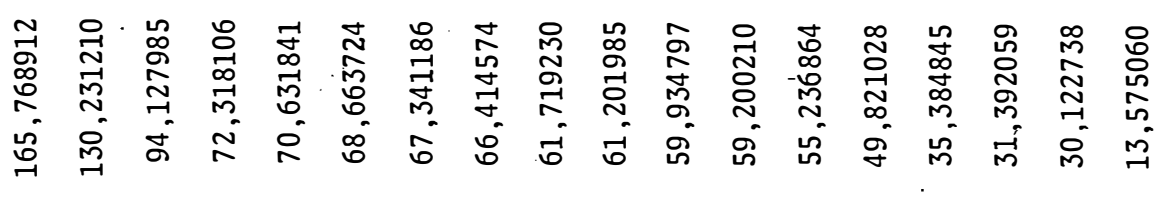

芯㣢总

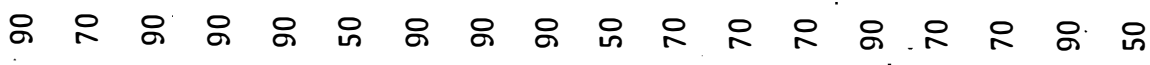

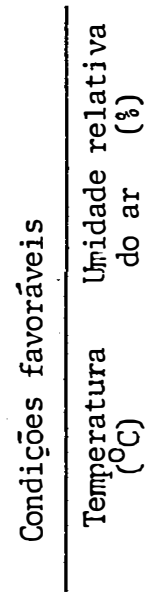

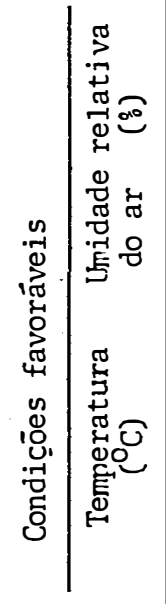

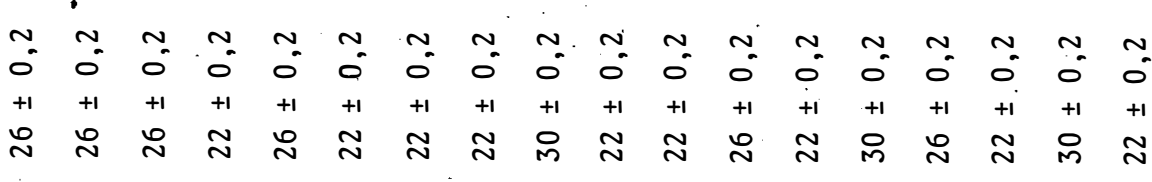

量

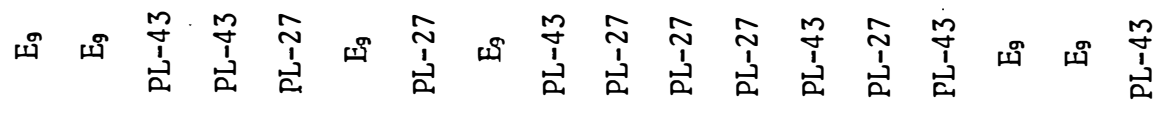


rão viáveis, no mínimo, por 96 horas. Este tempo pode ser con siderado como suficiente para que após uma aplicação do fungo a nîvel de campo, pelo menos, alguns indivíduos da população da praga entrem em contato com os conídios distribuídos, para que posteriormente ocorra a germinação desses conídios e o de senvolvimento do fungo sobre o inseto. RAMOSKA (1984) relatou que a umidade superficial do inseto é suficiente para que ocorra a germinação dos conídios e o processo de colonização do hospedeiro pelo patôgeno. Após o desenvolvimento do micélio, o ambiente que possui essas condições favoráveis irá permitir que ocorra sobre o cadáver do inseto, a formação de um grande número de conídios. Esses conídios poderão permanecer viáveis por, pelo menos 96 horas, podendo serem disseminados através da praga e por outros agentes de disseminação, provocando o aparecimento de uma epizootia e proporcionando um bom controle da praga.

Pode-se também constatar entre as condições cli mâticas favoráveis (Tabela 27), que a umidade relativa do ar de $50 \%$ somente foi favorável quando associada à temperatura de $22 \pm 0,2^{\circ} \mathrm{C}$. Isso pode ser devido ao efeito benéfico da temperatura que amenizou o efeito prejudicial da umidade de $50 \%$, não permitindo uma perda excessiva de água do interior dos conídios.

De outro lado, a temperatura de $30 \pm 0,2^{\circ} \mathrm{C}$ somen te foi favorável quando associada à umidade relativa do ar de $90 \%$. Isso provavelmente, pode ser devido à umidade elevada que não permitiu a dessecação dos conídios, o que já não aconteceu 
para a umidade relativa do ar de $70 \%$ na temperatura de $30 \pm 0,2^{\circ} \mathrm{C}$.

Em seguida, construiu-se vários climogramas con forme SILVEIRA NETO et alii (1976), com os dados de temperatu ra e umidade relativa do ar de diferentes regiões do Brasil (Apêndice 1) e traçou-se sobre estes gráficos, os pontos de temperatura e umidade relativa do ar que delimitam as condições favoráveis, tanto para obtenção de uma alta produção de conídios como para a manutenção da viabilidade desses conídios próxima de $100 \%$. Assim, foi possível obter um triângulo que delimitou a zona favorável para aplicação de conídios dos isó lados $E_{9}$, PL-27 e PL-43 de M. anisopliae. Dessa maneira, è provável que sob o ponto de vista ecológico, existam grandes pos sibilidades de desenvolvimento, adaptação, instalação e expan são deste fungo em qualquer região que possua essas condições. Esse método permite determinar com alguma base científí ca, a partir de que més e até quando se pode aplicar o patóge no sobre a praga visada nas diferentes regiões.

Verifica-se através da Figura 11 , que na região de Belém (PA) pode-se aplicar o fungo durante qualquer época do ano, pois se trata de uma região altamente favorável aos $\underline{i}$ solados $\mathrm{E}_{9}, \mathrm{PL}-27$ e $\mathrm{PL}-43$, podendo inclusive ocorrer epizootias naturais.

Na Figura 12, observa-se que a região de Quixa dá (CE) não oferece condições para aplicação do patógeno durante todos os meses do ano. 
.105.

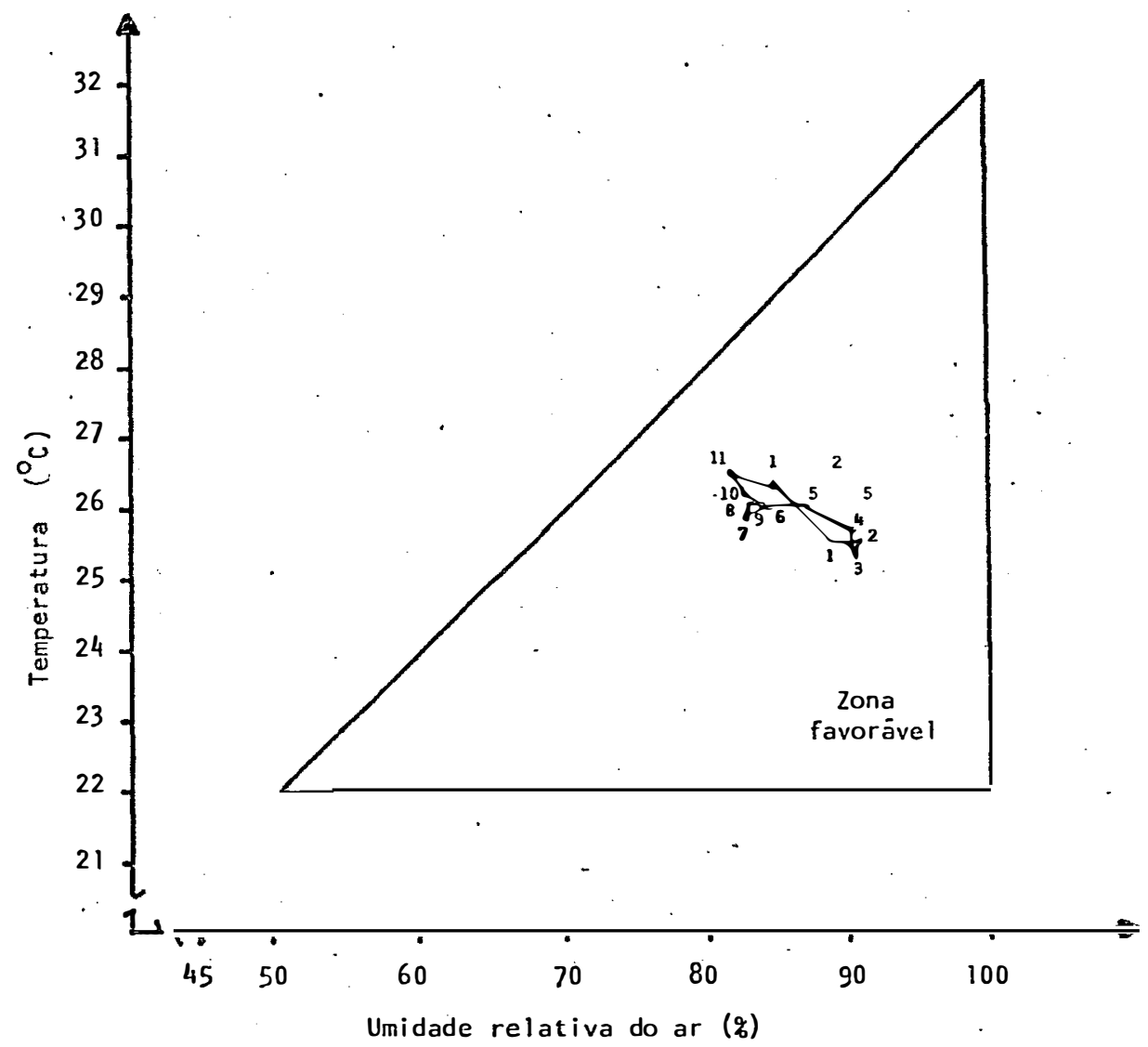

Figura 11. Climograma comparativo entre a região de Belém (PA) e a zona favorável à una alta produção de conídios viāveis dos isolados $\mathrm{E}_{9}, \mathrm{PL}-27$ e $\mathrm{PL}-43$ de $M$. anisopliae. 


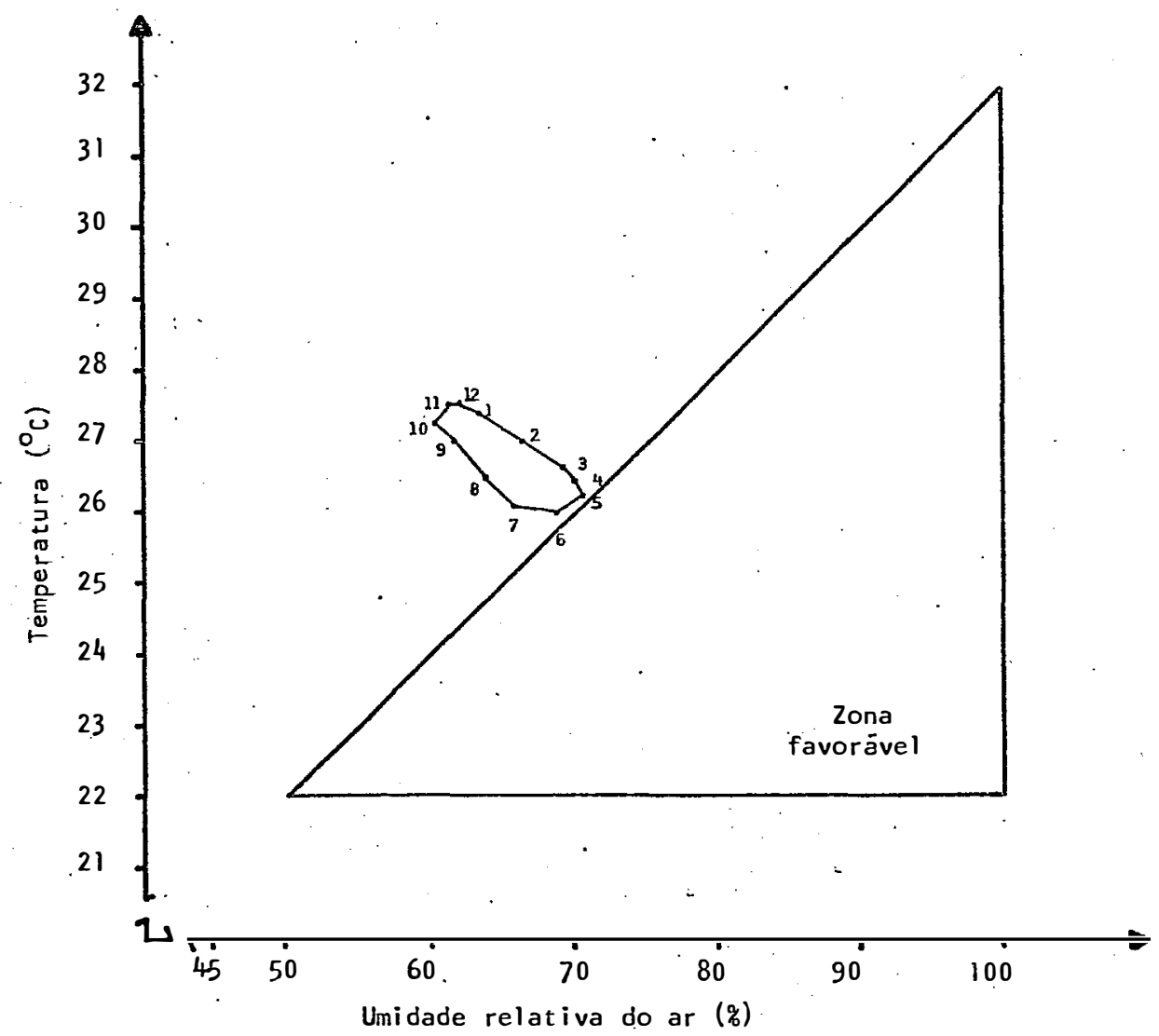

Figura 12. Climograma comparativo entre a região de Quixadá (CE) e a zona favorável à uma alta produção de conídios viáveis dos isolados $\mathrm{E}_{9}, \mathrm{PL}-27$ e PL-43 de Metarhizium anisopliae. 
Através da Figura 13 , observa-se que a região de Cuiabā (MT) apresenta condições climāticas favorāveis ao fungo no período de novembro a julho, e serve de exemplo de re gião onde dificilmente poderá ocorrer epizootias naturais, com excessão de alguns topoclimas. Nessa região nos meses de agós to, setembro e outubro, o fungo dificilmente poderá resistir às condições climáticas desfavoráveis que são características desses meses ao longo dos anos. Esta região é também exemplo do que ocorre na maioria das regiões do Brasil (Centro-Oeste e Sudeste) onde se utiliza o M. anisopliae para o controle das cigarrinhas-das-pastagens. Isso demonstra á necessidade da aplicação do fungo se tornar um método de rotina durante a ocorrência da praga.

Os meses favoráveis e desfavoráveis para aplicação dos isolados $E_{9}$, PL-27 e PL-43 em outras regiões, estão resumidos na Figura 14 , onde se observa que a região de Recife (PE) apresenta condições favoráveis à aplicação desses iso lados durante, praticamente, todo o ano. Essas condições também favorecem a ocorrência de epizootias do fungo sobre $M$. posticata, conforme foi relatado por ALVES et alii (1982) na região canavieira do litoral nordestino, reforçando a validade do modelo proposto, que é a utilização dos conhecimentos so bre as exigências térmicas e hídricas do M. anisopliae com base em climogramas. 


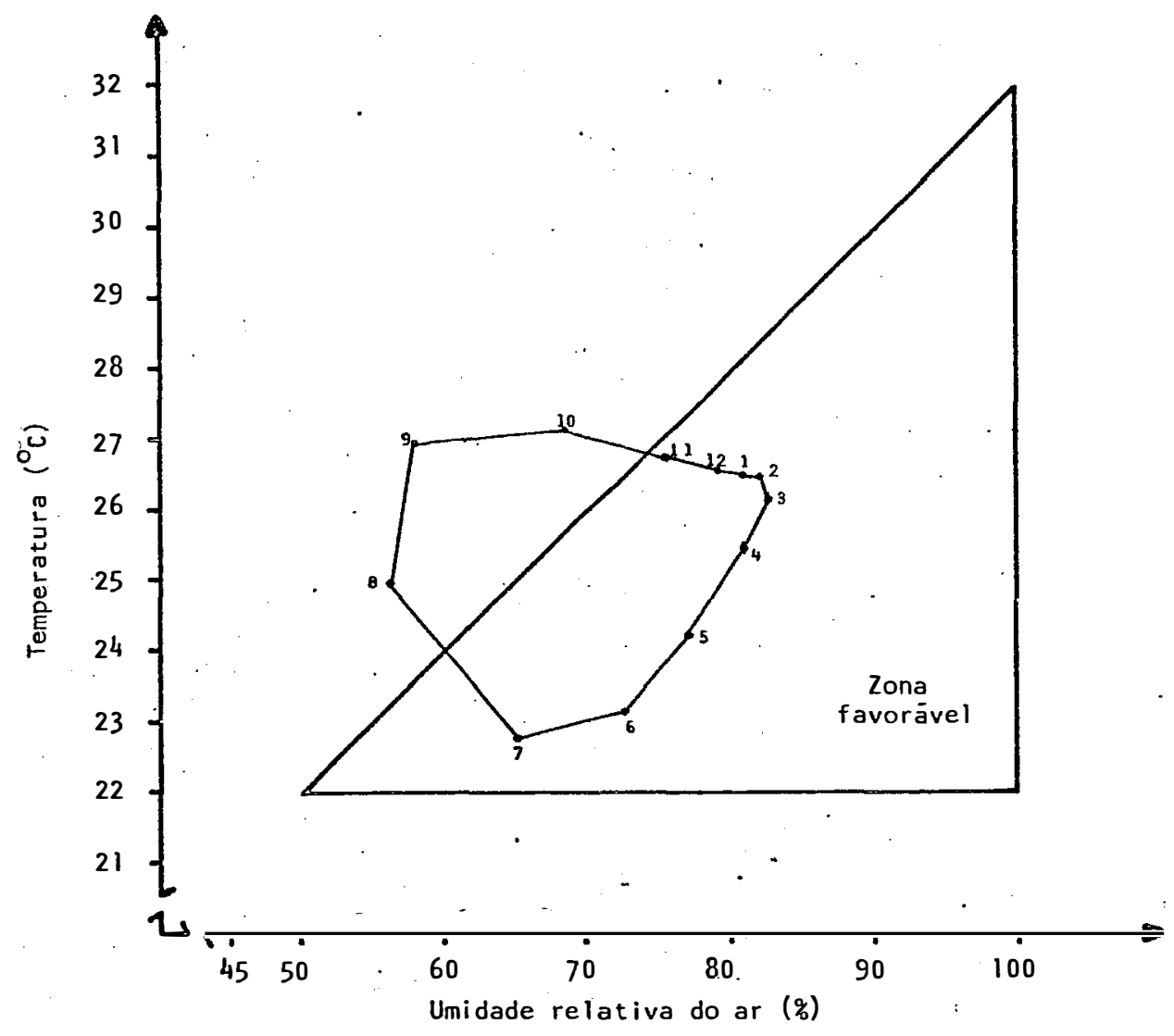

Figura 13. Climograma comparativo entre a região de Cuiabá (MT) e a zona favorável à uma alta produção de conídios viáveis dos isolados $\mathrm{E}_{9}, \mathrm{PL}-27 \cdot \mathrm{e} \mathrm{PL}-43$ de Metarhizium anisopliae. 


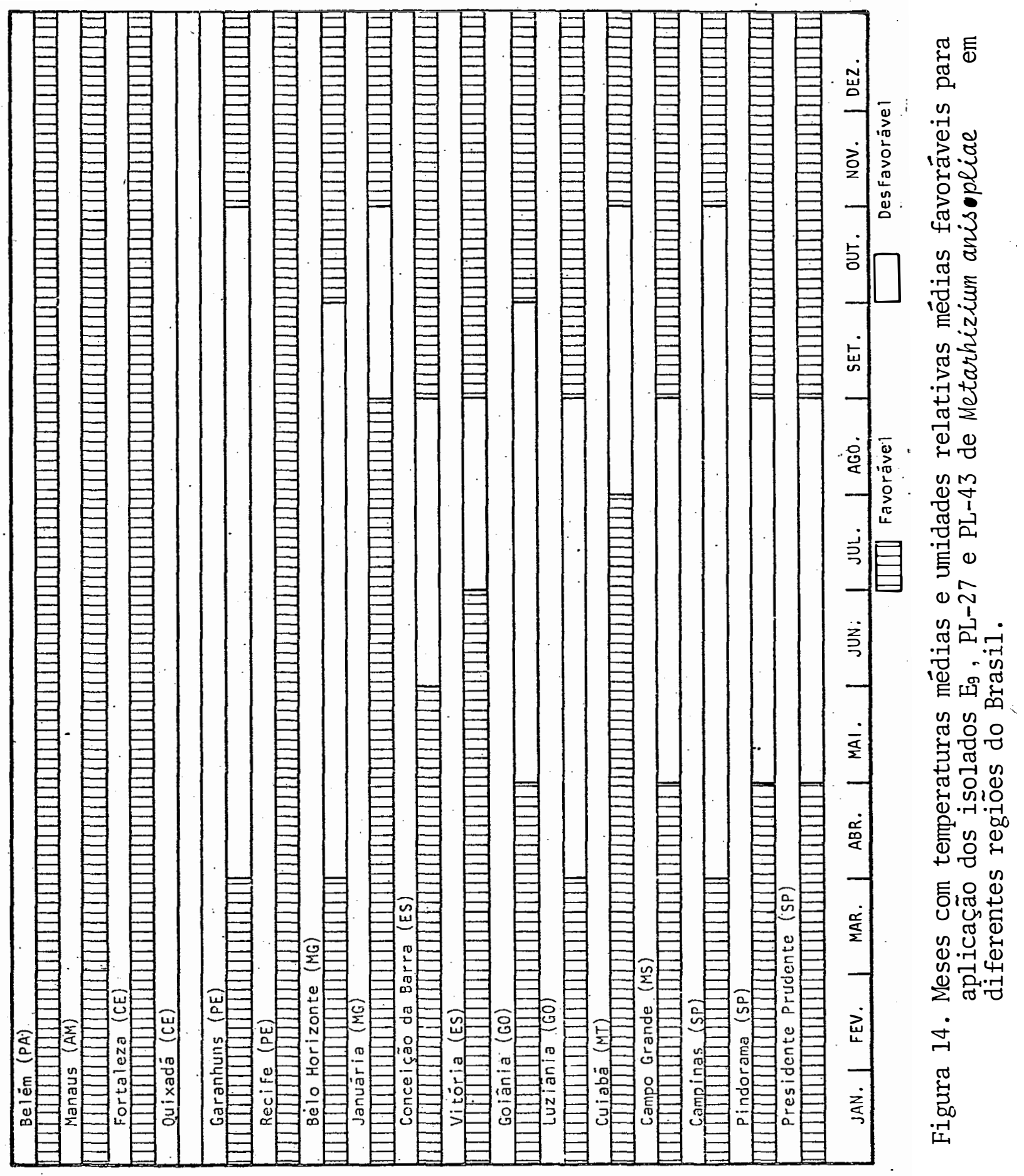




\section{CONCLUSÕES}

Com base nos resultados obtidos e para as con dições em que os testes foram executados, as seguintes conclu sões podem ser feitas:

1. O tempo de 48 horas de incubação é o mais in dicado para se comparar a produção de conídios dos isolados $E_{9}$, PL-27 e PL-43 de $M$. anisopliae sobre cadáveres de lagartas de D. saccharalis mantidas em diferentes tempe raturas e umidades relativas do ar.

2. A temperatura e a umidade relativa do ar influenciam na produção de conídios sobre o hospedeiro. 
3. As produções de conídios mais elevadas dos isolados $E_{9}$, PL-27 e PL-43 foram obtidas nas temperaturas de: $26^{\circ} \mathrm{C}$ associada a umidades relativas do ar de 90 e $70 \% ; 22^{\circ} \mathrm{C}$ associada a umidades relativas do ar de $30,50,70$ e $90 \%$ e $30^{\circ} \mathrm{C}$ associada a umidades relativas do ar de 90 e $70 \%$.

4. Os isolados $E_{9}$, PL-27 e PL-43 apresentambai xa produção de conídios em qualquer umidade relativa do ar, quando a temperatura é igual a $34{ }^{\circ} \mathrm{C}$, sendo o isolado PL-27 o mais sensive1 a esta temperatura.

5. A influência das diferentes umidades relati vas do ar sobre a produção de conídios é mais pronunciada na temperatura de $26^{\circ} \mathrm{C}$, on de se observa que a medida que a umidade se eleva, a produção de conídios também aumenta.

6. A temperatura de $22^{\circ} \mathrm{C}$ inibe a influência das diferentes umidades relativas do ar sobre a produção de conídios dos isolados $E_{9}$, PL-27 e $\mathrm{PL}-43$. 
7. A influência das diferentes temperaturas so bre a produção de conídios é mais pronuncia da na umidade relativa do ar de $90 \%$

8. A umidade relativa do ar de $30 \%$ inibe a influência das diferentes temperaturas so-。 bre a produção de conídios dos isolados $E_{9}$, PL-27 e PL-43.

9. O tempo de 96 horas de incubação é o mais in dicado para se comparar a viabilidade dos conídios dos isolados $E_{9}, \mathrm{PL}-27$ e PL-43 produzi dos sobre cadáveres de lagartas de $D$. saccharalis mantidos em diferentes temperaturas e umidades relativas do ar.

10. A temperatura e a umidade relativa do ar in fluenciam na manutenção da viabilidade dos conídios sobre o hospedeiro.

11. A viabilidade dos conídios dos isolados $E_{9}$ PL-27 e PL-43 que se mantiveram prôximas de $100 \%$, foram obtidas nas temperaturas de : $22^{\circ} \mathrm{C}$ associada a umidades relativas do ar de 90,70 e $50 \% ; 26^{\circ} \mathrm{C}$ associada a unidades relativas do ar de 90 e $70 \% ; 30^{\circ} \mathrm{C}$ e $34^{\circ} \mathrm{C}$ quando associadas a u- 
midade relativa do ar de $90 \%$

12. A temperatura de $22^{\circ} \mathrm{C}$ ameniza o efeito prejudicial das baixas umidades relativas do ar sobre a viabilidade dos conídios dos iso lados até o limite mínimo de $50 \%$.

13. A influência das diferentes umidades relati vas do ar sobre a viabilidade dos conídiosé mais pronunciada na temperatura de $26^{\circ} \mathrm{C}$, on de se observa que a medida que a umidade re lativa decresce, a viabilidade dos conídios tambēm decresce.

14. A umidade relativa do ar de $90 \%$ ameniza o efeito prejudicial de temperaturas como $30^{\circ} \mathrm{C}$ e $34^{\circ} \mathrm{C}$ sobre a viabilidade dos conídios dos isolados $E_{9}$, PL-27 e PL-43.

15. A umidade relativa do ar de $30 \%$ é prejudicial à viabilidade dos conídios em qualquer uma das temperaturas testadas.

16. As exigências têrmicas e hîdricas para se obter alta produção de conídios dos isolados $E_{9}$, PL-27 e PL-43 e para a manutenção da via 
bilidade desses conídios próxima de $100 \%$, são atendidas nas seguintes combinações de temperatura e umidade relativa do ar: $22^{\circ} \mathrm{C}$ e umidades iguais ou superiores a $50 \% ; 26^{\circ} \mathrm{C}$ e umidades iguais ou superiores a $70 \% ; 30^{\circ} \mathrm{C}$ e umidades iguais ou superiores a $90 \%$.

17. E possível a utilização de climogramas com base nas exigências têrmicas e hídricas do fungo, visando estabelecer êpocas de aplica ção e a previsão da ocorrência de epizootias nas diferentes regiões do país. 


\section{LITERATURA CITADA}

ALVES, S.B., 1982. Caracterização, padronização e produção do Metarhizium anisopliae (Metsch.) Sorok. Piracicaba, ESALQ/USP, 95p. (Tese de Livre Docência).

ALVES, S.B., 1984. Controle biológico de pragas de pastagens In: Simpósio sobre Manejo de Pragas de: Pastagens, 7., Piracicaba, FEALQ. Anais, p.169-208.

ALVES, S.B., 1985. Patologia de Insetos. Apostila do Curso de Pós-Graduação em Entomologia. Piracicaba, ESALQ/USP, $580 \mathrm{p}$. 
ALVES, S.B. e N.L. NOGUEIRA, 1984. Efeito da temperatura na germinação e viabilidade do Metarhizium anisopliae (Metsch.) Sorok. In: Congresso Brasileiro de Entomologia, 9., Londrina. Resumos, p.170.

ALVES, S.B. e S.H. RISCO, 1983. Influência da radiação ultra-violeta de $2537 \AA$ sobre a germinação de 15 isolados de Metarhizium anisopliae (Metsch.) Sorok. In: Congresso Brasileiro de Entomologia, 8., Brasília. Resumos, p.246.

ALVES, S.B.; S.H.RISCO e L.C. ALMEIDA, 1982: Evaluation of spore amounts of Metarhizium anisopliae (Metsch.) Sorok. produced per hectare during the epizootic phase of the disease on sugarcane leafhopper, Mahanarva posticata. Entomology Newsletter. Araras, 13: 7 .

ALVES, S.B.; J.W.N. CHAVES; N. MACEDO e S. SILVEIRA NETO, : 1984a. Patogenicidade do Metarhizium anisopliar. (Metsch.) Sorok. isolado PL-27 sobre lagartas de Diatraea saccharalis Fabr. em diferentes temperaturas. In: Congresso Brasileiro je Entomologia, 9., Londrina. Resumos, p.169.

ALVES, S.B.; S.H. RISCO e L.C. ALMEIDA, 1984b. Influence of photoperiod and temperature on the development and sporulation of Metarhizium anisopliae (Metsch.) Sorok. Zeitschrift für angewandte Entomologie. Berlin, 97: 127-129. 
ALVES, S.B.; S.H. RISCO; S. SILVEIRA NETO e R. MACHADO NETO, 1984c. Pathogenicity of nine isolates of Metarhizium anisopliae (Metsch.) Sorok. to Diatraea saccharalis (Fabr.). Zeitschrift für angewandte Entologogie. Berlin, 97: 403-406.

ALVES, S.B.; S. SILVEIRA NETO e M.L. HADDAD, 1984d. Capacidade de sobrevivência do Metarhizium anisopliae (Metsch.) Sorok. (isolado $E_{g}$ ) sobre cana-de-açúcar, nas condições de campo. O Solo. Piracicaba, (1): 39-42.

AQUINO, M.L.N., 1974. O fungo entomógeno Metarhizium anisopliae (Metsch.) Sorokin, no Estado de Pernambuco. Boletim Técnico. do Instituto de Pesquisas Agronômicas. Recife, 72: 1-26.

AQUINO, M.L.N.; V.A.L.B. CAVALCANTI; R.C. SENA e G.F. QUEIROZ, 1975. Nova tecnologia de multiplicação do fungo Metarhizium anisopliae. Boletim Técnico da CODECAP. Recife, 4: 1-31.

BALFOUR-BROWNE, F.L., 1960. The green muscardine diseases of insects, with special reference to an epidemic in a swarm of locusts in eritrea. Proceedings of Royal Entomological Society of London. Serie A. London, 35: 65-74.

BARON, G., 1968. The genera of hyphomycetes from soil. Baltimore, Willians \& Willians Company. 686p. 
BASTOS, C.N. e E.A.F. DA MATTA, 1976. Influência das temperaturas e luz na esporulação do fungo Metarhizium anisopliae (Metsch.) Sorok. Boletim do Instituto. Biológico da Bahia. Salvador, 15: (1): 5-8.

BELL, J.V., 1974. Mycoses. In: CANTWELL, G.E. Insects Diseases. New York, Marcel Dekker, p.185-230.

BELL, J.V. e R.J. HAMALLE, 1974. Viability and pathogenicity of entomogenous fungi after prolonged storige on silica gel at $-20^{\circ} \mathrm{C}$. Canadian Journal of Microbiology. Ottawa, 20: $639-642$.

BORGES, V.E., 1985. Estudo de isolados de Metarhizium anisopliae (Metsch.) Sorokin, 1883 para controle da cigarrinha-das-pastagens. Piracicaba, ESALQ/USP, 99p. (Dissertação de Mestrado).

BRASIL. Ministério da Agricultura, 1969a. Normais. Climatológicas: (Acre-Amazonas-Pará-Maranhão). Rio de Janeiro, Escritório de Meteorologia, vol. 1 .

BRASIL. Ministērio da Agricultura, 1969b. Normais Climatólógicas: (Piauí-Rio Grande do Norte-ParaíbaPernambuco-Alagoas-Sergipe-Bahia). Rio de Janeiro, Escritório de Meteorologia, vol. 2 . 
BRASIL. Ministério da Agricultura, 1969c. Normais.

Climatológicas: (Minas Gerais-Espírito Santo-Rio de Janeiro-Guanabara). Rio de Janeiro, Escritório de Meteorologia, vol. 3 .

BRASIL. Ministério da Agricultura, 1969d. Normais. Climatológicas: (Mato Grosso-Goiás). Rio de Janeiro Escritório de Meteorologia, vol.5.

BURGUES, H.D., 1981. Strategy for the Microbial Control of Pests in 1980 and Beyond. In: BURGUES, H.D., Ed. Microbial. Control of Pests and Plant Diseases, 1970-1980. New York, Academic Press, p.797-836.

CAMARGO, A.P. de, 1966. Viabilidade e limitações climáticas para a cultura do milho no Brasil. In: MORGENTHALER, J. Coord. Cultura e adubação do milho. São Paulo, Instituto Brasileiro de Potassa, p.225-247.

CAMERON, J.W.M., 1963. Factors affecting the use of microbial pathogens in insect control. Annual Review of Entomology, 8: $265-286$. 
CAMPOS GUEVARA, L.A., 1983. Previsão de ocorrência e zoneamento ecológico de Heliothis virescens (Fabr., 1781) (Lepidoptera: Noctuidae) em cultura de algodão. Piracicaba, ESALQ/USP, 117p. (Tese de Doutorado).

CLERK, G.C. e M.F. MADELIN, 1965. The longevity of three insect parasitizing hyphomycetes. Transactions British Mycological Society, 48: 193-209.

COCHRANE, V.W., 1958. Physiology of fungi. New York, John Wiley and Sons, Inc. 524 p.

DAOUST, R.A. e D.W. ROBERTS, 1983. Studies on the prolonged storage of Metarhizium anisopliae conidia: Effect of temperature and relative humidity on conidial viability and virulence against mosquitoes. Journal of Invertebrate Pathology. New York, 41: 143-150.

DAOUST, R.A.; M.G. WARD e D.W. ROBERTS, 1983. Effect of formulation on the viability of Metarhizium anisopliae conidia. Journal of Invertebrate Pathology. New York, 41: $151-160$.

DAOUST, R.A.; M.G. WARD e D.W. ROBERTS, 1982. Effect of formulation on the virulence of Metarhizium anisopliae conidia against mosquito larvae. Journal of Invertebrate Pathology. New York, 40: 228-236. 
DIOMANDE, T., 1969. Contribution to the study of the development of the green muscardine fungus Metarhizium anisopliae on 0 . monoceros larvae. Bulletin of Institute. Fondam Afrique Noire, Serie A, 31: 1381-1405.

DOBERSKY, J.W., 1981. Comparative laboratory studies on three fungal pathogens on the elm beetle scolytus scolytus: Effect of temperature and humidity on infection by Beauveria bassiana, Metarhizium anisopliae, and Paecilomyces barinosus. Journal Invertebrate Pathology. New York, 37: $195-200$.

DUNN, P.H. e B.J. MECHALAS, 1963. The potencial of Beauveria bassiana (Bals.) Vuillemin as a microbial insecticide. Journal of Insect Pathology, 5: 451-459.

FARGUES, J.; T. DURIEZ; J. ANDRIEU; R. POPEYE e P. ROBERT, 1975: Etude immunologique compareé de souches de Metarhizium anisopliae (Delacr.). Sien champignon hyphomycéte entomopathogéne. Comptes Rendus. Hebdomadaires des Séances. de 1'Acadêmie des Sciences, Serie D., 281: 1781-1784.

FERRON, P., 1977. Influence of relative humidity on the development of fungal infection caused by Bequveria bassiana (Fungi imperfecti, Moniliales) in imagines of Acanthoscelides obtectus (Col. Bruchidae). Entomophaga, 22: (4): 393-396. 
FERRON, P. 1978. Etiologie et epidemiologie des muscardines. Paris, Université Pierre e Marie Curie, 112p. (These de Doctorat D'Etat).

FERRON, P., 1981. Pest control by the fungi Beauveria and Metarhizium. In: BURGUES, H.D., Ed. Microbial Control. of Pests Diseases, 1970-1980. New York, Academic Press, p. $465-482$.

GALLI, F. e P.C.T. CARVALHO, 1978. Ciclo das relações patógenohospedeiro. In: GALLI, F., Coord. Manual de Fitopatologia. 2. ed. São Paulo, Editora Agronômica Ceres, p.176-198.

GAUMANN, E., 1950. Principles of plant infection. London, Crosby Lockwood \& Son, Ltd. 543p.

GUAGLIUMI, P.; E.J. MARQUES e A.M. VILAS BOAS, 1974. Contribuição ao estudo da cultura e aplicação de Metarhizium anisopliae (Metsch.) Sorok. no controle da cigarrinha da folha Mahanarva posticata (Stal) no Nordeste do Brasil. Recife, CODECAP, 54p. (Boletim Técnico, 3).

KENDRICK, W.B., 1971. Taxonomy of fungi imperfecti. University of Toronto Press. 309p. 
KISH, L.P. e G.E. ALLEN, 1978. The biology and ecology of Nomuraea rileyi and a program for predicting its incidence on Anticarsia gemmatalis in soybean. Gainesville, University of Florida, 48p. (Fla. Agric. Exp. Stn. Bull, 795) .

LATCH, G.C,M., 1965. Metarhizium anisopliae (Metschnikoff) Sorokin strains in New Zealand and their possible use for controlling pasture inhabiting insects. New Zealand Journal of Agricultural Research. Wellington, 8: 384-396.

LINGG, A.L. e M.D. DONALDSON, 1981. Biotic and abiotic factors affecting stability of Beauveria bassiana conidia in soil. Journal of Invertebrate Pathology. New York, 38: 191-200.

MARQUES, E.J.; A.M. VILAS BOAS e C.E.F. PEREIRA, 1981. Orientações técnicas para produção do fungo entomógeno Metarhizium anisopliae (Metsch.) Sorok. em laboratórios setoriais . Boletim Técnico do PLANALSUCAR. Piracicaba, $\underline{3}(2): 1-23$.

MASERA, E., 1957. Metarhizium anisopliae (Metsch.) Sorokin, a parasita del baco da seta. Annali della Sperimentazione Agraria, 11:281-295. 
MENDES, A.C.; P.S.M. BOTELHO; N. DEGASPARI e S.M.S.S. ARAÚJO, 1980. Desenvolvimento do combate biológico da Diatraea saccharalis (Fabr. 1794) (Lep:Pyralidae), na Coordenadoria Regionaj. Sul, importância, resultados e perspectivas futuras. In : Encontro Nacional dos Entomologistas do IAA/PLANALSUCAR, 5., Itajaí, 14-19 de abril.

MILNER, R.J. e G.G. LUTTON, 1976. Metarhizium anisopliae: survival of conidia in the soil. Intern. Colloq. Pathol. 1., Kingston. Anais, p.428-429.

MOSCARDI, F. e I.C. CORSO, 1981. Teste de fungicidas para o controle da incidência do fungo Beauveria sp. em Bombyx mori Linnaeus, 1758. Anais da Sociedade Entomológica do. Brasil, 10.(1): 129-133.

MURAYAMA, M. Y.; S.B. ALVES e L.C. ALMEIDA, 1982. Efeito de repicagens em meio de arroz na patogenicidade, morfologia e produção de esporos de Metarhizium anisopliae (Metsch.) Sorok. Boletim do Grupo de Pesquisadores de Controle. Biológico. Brasília, $\underline{3}: 12$.

OLIVEIRA; D.P. de; G.M. CHAVES e E.G. LAURES, 1981. Estudo comparativo da sobrevivência de Metarhizium anisopliae (Metsch.) Sorokin em diferentes tipos de solo. Revista Theobroma. I1héus, 11(4): 233-239. 
PARRA, J.R.P., 1981. Biologia comparada de Perileucoptera cofbeella (Guérin-Mènev., 1842) visando o seu zoneamento ecológico no Estado de São Paulo. Piracicaba, ESALQ/USP, 96p. (Tese de Livre-Docência).

PEREIRA, J.0.; A.C. MONTEIRO; E.O. RUFINO e B.M. MASCARENHAS 1982. Controle biológico: interação fungo-inseto na região Amazônica. Boletim do Grupo de Pesquisadores de Controle. Biológico. Brasília, 3 : 12 .

PETCH, T., 1931. Notes on entomogenous fungi. Transactions. British Micological Society, 16: 55-75.

PUZZI, D. e A.P. de CAMARGO, 1963. Estudo sobre a possibilidade da adaptação climática de Orthezia praelonga Douglas nos pomares de citros do Estado de São Paulo. O Biológico. São Paulo, 29:81-85.

RAMOSKA, W.A., 1984. The influence of relative humidity on Beauveria bassiana infectivity and replication in the chinch bug Blissus leucopterus. Journa1 of Invertebrate Pathology. New York, 43: 389-394. 
RIBA, G. e S. MARCANDIER, 1984. Influence de 1'humidité relative sur l'agressivité et la viabilitê des souches de Beauveria bassiana (Bals.) Vuillemim et de Metarhizium anisopliae (Metsch.) Sorokin, hyphomycêtes pathogènes de la pyrale du maīs, Ostrinia nubiläis Hübn. Agronomie, 4(2): 189-194.

ROBERTS, D.W. e A.S. CAMPBELL, 1977. Stability of entomogenous fungi. Mis. Pub1. Entomo1. Soc. Am., 10(3): 19-75.

SANTOS, A.L.L., 1978. Influência de alguns fatores no crescimenti, germinação e produção de conîdios de Metarhizium anisopliae (Metsch.) Sorokin. Piracicaba, ESALQ/USP, 148p. (Dìssertação de Mestrado).

SÃo PAULO. Secretaria de Agricultura. Instituto Agronômico de Campinas, 1986. Arquivo de dados climatológicos. Campinas, Seção de Climatologia Agrícola. :

SCHABEL, H.G., 1976. Oral infection of Hylobius pales by Metarhizium anisopliae. Journal of Invertebrate Pathology. New York, 27: 377-383.

SCHAERFFENBERG, B. 1964. Biological and enviromental conditions for the development of mycoses caused by Beauveria and Metarhizium. Journal of Insect Pathology, 6: 8-20. 
SILVEIRA, G.A. e C.L. MESSIAS, 1983. Infecção de Deois sp. por Metarhizium anisopliae - penetração e colonização. Boletim do Grupo de Pesquisadores de Controle Biológico. Brasilia, 4: 14 .

SILVEIRA NETO, S.; O. NAKANO; D. BARBIN e N.A. VILLA NOVA, 1976. Manual de Ecologia dos Insetos. Piracicaba, Editora Agronômica Ceres. 419p.

SILVEIRA NETO, S.; J.R.P. PARRA; R.A.ZUCHI e S.B. ALVES, 1986. Zoneamento ecológico para as cigarrinhas de pastagens no Brasil. In: Congresso Brasileiro de Entomologia, 10., Rio de Janeiro. Resumos, p. 127.

SOSA GOMEZ, D.R., 1983. Caracterização e padronização de isolados de Metarhizium anisopliae (Metsch.) Sorokin, 1883 provenientes de diferentes regiōes do Brasil. Piracicaba, ESALQ/USP, 117 p. (Dissertação de Mestrado).

SOSA GOOMEZ, D.R. e S.B. ALVES, 1983. Caracterização de once aislamentos de Metirhizium anisopliae (Metsch.) Sorok. 1. Estandarización, virulencia y actividad enzimâtica. CIRPON, Rev. Invest., 1 (3): 83-102.

TANADA, Y., 1963. Epizootiology of Infectious Diseases. In: STEINHAUS, E.A. Ed. Insect pathology: an advanced treatise. New York, Academic Press, v. 2, p. 423-475. 
TULLOCH, M., 1976, The genus Metarhizium. Transactions. British Mycological Society, 66: 407-411.

VENTURA, J.A., 1981. Epizootiologia. Boletim do Grupo de Pesquisadores de Controle Biológico. Brasilia, 2:12.

VILLACORTA, A., 1978. Efeito da temperatura e da nutrição sobre o desenvolvimento de vâríos isolamentos de Metarhizium anisopliae Sorok. In: Congresso Latinoamericano de Entomologia, 3. e Congresso Brasileiro de Entomologia, 5., Il héus/Itabuna. Resumos, p.70

VILLACORTA, A., 1980. Suscetibilidade de ninfas de Deois Glavopicta (Sta1., 1854). (Homoptera:Cercopidae) a diferentes isolamentos de Metarhizium anisopliae (Metsch.) Sorokin. Anais da Sociedade Entomologica do Brasil, $9(1): 33-38$.

WALSTAD, J.D. e ANDERSON, R.J., 1971. Effectiveness of Beauveria bassiana and Metarhizium anisopliae as control agents for the pales weevil (Hylobius pales (Herbst.): Curculionidae). Journal of Economic Entomology. College Park, 64: 322-323. 
WALSTAD, J.D.; R.F. ANDERSON e W.J. STAMBAUGH. Effects of envijonmental conditions on two species of muscardine fungi (Beauveria bassiana and Metarhizium anisopliae). Journal of Invertebrate Pathology. New York, 16: 221-226.

WEISER, J., 1982. Persistence of fungal insecticides: influence of environmental factors and future applications. In: KURSTAK, E., Ed. Microbial and Viral Pesticides. New York, Marcel Dekker, Inc., p.531-557.

ZIMMERMANN, G., 1982. Effect of high temperatures and artificial sunlight on the viability of conidia of Metarhizium anisopliae. Journal of Invertebrate Pathology. New York, 40: 36-40. 
.130 .

7. APÊNDICE 
Apêndice 1. Temperanaras médias mensais e umidades relativas médias mensais de diferentes regiōes do Brasil.

\begin{tabular}{|c|c|c|c|c|c|c|c|c|c|c|c|c|c|}
\hline Local & $\begin{array}{c}\text { Dado } \\
\text { climático }\end{array}$ & Jan. & Fev. & Mar. & Abr. & Mai & Jun. & Jul. & Ago. & Set. & Out. & Nov. & Dez. \\
\hline \multirow[t]{2}{*}{ Belēm (PA) } & Temp. Média $\left({ }^{\circ} \mathrm{C}\right)$ & 25.6 & 25,5 & 25.4 & 25,7 & 26,0 & 26,0 & 25,9 & 26,0 & 26,0 & 26,2 & 26,5 & 26,3 \\
\hline & Unid.Rel.Média(3) & 88,8 & 90,7 & 90,7 & 90,4 & 87.2 & 84,5 & 83.2 & 83,4 & 83,8 & 82,8 & 81,8 & 84,9 \\
\hline \multirow[t]{2}{*}{ Manaus (AM) } & Temp. Média $\left({ }^{\circ} \mathrm{C}\right)$ & 25,9 & 25,8 & 25,8 & 25,8 & 26.4 & 26,6 & 26,9 & 27.5 & 27,9 & 27,7 & 27,3 & 26,7 \\
\hline & Umid.Rel.Média(\&) & 87,7 & 87,8 & 88.2 & 88,5 & 86,2 & 83,0 & 79,7 & 77,2 & 77.5 & 79,4 & 82,1 & 85,2 \\
\hline \multirow[t]{2}{*}{ Fortaleza (CE) } & Temp. Média $\left({ }^{\circ} \mathrm{C}\right)$ & 27,2 & 27,2 & 26,8 & 26,8 & 26.7 & 26,1 & 26,0 & 26,0 & 26,4 & 26,8 & 26,9 & 27.2 \\
\hline & Unid.Rel.Média(タ) & 77,4 & 79,9 & 81,9 & 82,2 & 80,1 & 78,1 & 75,3 & 73,3 & 73,7 & 72,9 & 74.2 & 75,4 \\
\hline \multirow[t]{2}{*}{ Quixadä(CE) } & Temp.Média $\left({ }^{\circ} \mathrm{C}\right)$ & 27,4 & 27,0 & 26,6 & 26,4 & 26,2 & 26,0 & 26,1 & 26,5 & 27,0 & 27,3 & 27,5 & 27,5 \\
\hline & Umid.Rel.Média(\&) & 63,2 & 66,6 & 69,3 & 70,0 & 70,6 & 68.8 & 66,0 & 63,7 & 61,8 & 60,5 & 61,5 & 62,0 \\
\hline \multirow[t]{2}{*}{ Garanhums (PE) } & Temp.Média $\left({ }^{\circ} \mathrm{C}\right)$ & 21,9 & 21,9 & $21 ; 9$ & 21,2 & 19,8 & 18,8 & 17,8 & 17,9 & 19.2 & 20,6 & 21,5 & 22,0 \\
\hline & Unid.Rel.Média(§) & 75,1 & 76,3 & 77.4 & 81,0 & 87,3 & 89,6 & 90,7 & 88,9 & 83,2 & 78,3 & 75,8 & 74,7 \\
\hline \multirow[t]{2}{*}{ Recife (PE) } & Temp.Média $\left({ }^{\circ} \mathrm{C}\right)$ & 27,0 & 27,1 & 27,0 & 26,6 & 25,6 & 24,7 & 24,2 & 24,2 & 25,0 & 25.9 & 26,4 & 26,7 \\
\hline & Umid.Rel.Média(\&) & 76,3 & 77,4 & $78,8-$ & 80,8 & 82,5 & 82,7 & 81,6 & 80,4 & 78,4 & 76,4 & 76,4 & 76,3 \\
\hline \multirow{2}{*}{$\begin{array}{l}\text { Belo } \\
\text { Horizonte (MG) }\end{array}$} & Temp.Média $\left({ }^{\circ} \mathrm{C}\right)$ & 22,8 & 22,9 & 22,3 & 21,1 & 19,1 & 18,0 & 17,7 & 19,0 & 20,8 & 21,5 & 21,7 & 21,6 \\
\hline & Unnid.Rel.Média(६) & 75,9 & 74,5 & 75,7 & 74,5 & 72,8 & 71,7 & 67,1 & 61,4 & 63,3 & 69,0 & 73,9 & 79,8 \\
\hline \multirow[t]{2}{*}{ Jamuária (AG) } & Temp.Média $\left({ }^{\circ} \mathrm{C}\right)$ & 25,1 & 25,3 & 25,2 & $24 ; 6$ & 23,3 & 22,2 & 22,0 & 23,4 & 25,5 & 26,4 & 25,2 & 24,7 \\
\hline & Umid.Rel.Média(§) & 78,7 & 76,6 & 78,1 & 75,5 & 72,2 & 69,2 & 63,8 & 57,4 & 56,8 & 63,4 & 75,5 & 80,6 \\
\hline \multirow{2}{*}{$\begin{array}{l}\text { Conceiçāo da } \\
\text { Barra (ES) }\end{array}$} & Temp.Média $\left({ }^{\circ} \mathrm{C}\right)$ & 25,9 & 26,1 & 25,8 & 24,6 & 23,1 & 22,0 & 21,3 & 21,6 & 22,6 & 23,6 & 24,3 & 25,1 \\
\hline & Unid.Rel.Média(q) & 83,2 & 83,4 & 84,1 & 84,2 & 84,3 & 85,5 & 84,5 & 82,4 & 82,5 & 83,6 & 85,0 & 84,7 \\
\hline \multirow[t]{2}{*}{ Vitória (ES) } & Temp.Média $\left({ }^{\circ} \mathrm{C}\right)$ & 25,7 & 26,0 & 25,7 & 24,3 & 22,9 & 21,9 & 21,0 & 21,4 & 22,2 & 23,0 & 23,7 & 24,7 \\
\hline & Umid.Rel.Média(\&) & 79,7 & 79,1 & 80,2 & 80,2 & 79.6 & 79,8 & 79,4 & 78,0 & 78,5 & 80,3 & 81,4 & 81,2 \\
\hline \multirow[t]{2}{*}{ Goiânia (ळ) } & Temp.MÉdia $\left({ }^{\circ} \mathrm{C}\right)$ & 22,8 & 23,0 & 22,8 & 22,2 & 20,4 & 18,9 & 18,8 & 21,2 & 23,2 & 23,6 & 23,0 & 22,7 \\
\hline & Umid.Rel .Média (q) & 80,8 & 81,6 & 82,3 & 77,9 & 72,2 & 68,0 & 61,8 & 51,6 & 54,0 & 67,6 & 78,3 & 81,6 \\
\hline \multirow[t]{2}{*}{ Luiziānia (GO) } & Temp.Média $\left({ }^{\circ} \mathrm{C}\right)$ & 21,9 & 22,0 & 21,7 & 21,1 & 19,4 & 18,3 & 18,1 & 20,0 & 22,1 & 22,3 & 21,9 & 21,6 \\
\hline & Umid.Rel.Média(\&) & 80,7 & 80,6 & 82,1 & 78,7 & 75,5 & 69,1 & 63,5 & 56,0 & 57,9 & 69,1 & 79,3 & 83,8 \\
\hline \multirow[t]{2}{*}{ Cuiabá (MT) } & Temp.^Édia $\left({ }^{\circ} \mathrm{C}\right)$ & 26,5 & 26,5 & 26,2 & 25,5 & 24,3 & 23,2 & 22,8 & 25,0 & 27,0 & 27,2 & 26,8 & 26,6 \\
\hline & Umid.Rel.Média(\&) & 80,8 & 82,0 & 82,5 & 81,0 & 77,1 & 72,6 & 65,3 & 56.4 & 58,0 & 68.7 & 75,7 & 79,1 \\
\hline \multirow[t]{2}{*}{ Campo Grande (MS) } & Temp.Média $\left({ }^{\circ} \mathrm{C}\right)$ & 24,3 & 24,3 & 23,8 & 22,0 & 20,3 & 19,3 & 19,1 & 21,1 & 22.8 & 23,5 & 24,0 & 24,5 \\
\hline & Umid.Rel.Mélia(६) & 79.6 & 81,0 & 79.8 & 77,7 & 76,0 & 73,1 & 67,8 & 58,9 & 62,3 & 69,2 & 72.2 & 75,4 \\
\hline \multirow[t]{2}{*}{ Cium, 2 nas $(S P)$} & Temp. Nédia $\left({ }^{\circ} \mathrm{C}\right)$ & 23,0 & 23,0 & 22,7 & 20,8 & 18,5 & 17,2 & 17,2 & 19,0 & 20,5 & 21,2 & 21,9 & 22,4 \\
\hline & Umid.Rel.Média(§) & 76,2 & 77,0 & 75,4 & 74,0 & 73,1 & 72,1 & 67,9 & 64,3 & 64.6 & 69.5 & 70.9 & 75,6 \\
\hline \multirow[t]{2}{*}{ Pindurama (SP) } & Temp.Média $\left({ }^{\circ} \mathrm{C}\right)$ & 24,0 & 23,9 & 23,5 & 21,8 & 19,7 & 18,6 & 18,6 & 20,7 & 22,6 & 23,3 & 23,6 & 23,7 \\
\hline & Umid.Rel.Média(§) & 79,5 & 80,0 & 78.2 & 73,7 & 71,3 & 70,2 & 63,7 & 57.9 & 60,2 & 68,5 & 71,2 & 77,6 \\
\hline \multirow{2}{*}{$\begin{array}{l}\text { Presidente } \\
\text { Prudente (SP) }\end{array}$} & Temp.Média $\left({ }^{\circ} \mathrm{C}\right)$ & 25,2 & 25,5 & 25.4 & 23,0 & 20,9 & 19.6 & 19,4 & 21,2 & 22,2 & 23,3 & 24,0 & 24,6 \\
\hline & Umid.Rel.Média(\&) & 78,5 & 78,5 & 76.7 & 72,7 & 72,3 & 72,4 & 67,2 & 63,2 & 67,6 & 71,0 & 72,7 & 78,1 \\
\hline
\end{tabular}

